\title{
Discovery of CNS Penetrant CXCR2 Antagonists for the Potential Treatment of CNS Demyelinating Disorders
}

\author{
Heng Xu, ${ }^{*} \ddagger$ Hongfu Lu, ${ }^{\dagger}$ Zhongmiao Xu, ${ }^{\dagger}$ Linbo Luan, ${ }^{\dagger}$ Chengyong Li, ${ }^{\dagger}$ Yan Xu, ${ }^{\dagger}$ Kelly Dong, ${ }^{\dagger}$ \\ Jinqiang Zhang, ${ }^{\dagger}$ Xiong Li, ${ }^{\dagger}$ Yvonne Li, ${ }^{\dagger}$ Gentao Liu, ${ }^{\dagger}$ Sophie Gong, ${ }^{\dagger}$ Yong-Gang Zhao, ${ }^{\dagger}$ Ailian \\ Liu, ${ }^{\dagger}$ Yueting Zhang, ${ }^{\dagger}$ Wei Zhang, ${ }^{\dagger}$ Xin Cai, ${ }^{\dagger}$ Jia-Ning Xiang, ${ }^{\dagger}$ John D. Elliott, ${ }^{\dagger}$ Xichen Lin*, ${ }^{\dagger}$
}

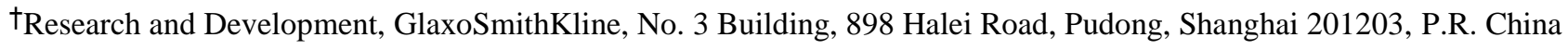
¥State Key Laboratory of Bioactive Substances and Function of Natural Medicine, Institute of Materia Medica, Peking Union Medical College and Chinese Academy of Medical Sciences, 1 Xiannongtan Street, Beijing 100050, P.R. China

\begin{abstract}
Structure-activity relationship exploration of the historical biarylurea series led to the identification of novel CNS penetrant CXCR2 antagonists with nanomolar potency, favorable PK profile and good developability potentials. More importantly, the key compound 22 showed efficacy in a cuprizone-induced demyelination model with twice daily oral administration, thereby supporting CXCR2 to be a potential therapeutic target for the treatment of demyelinating diseases such as multiple sclerosis.
\end{abstract}




\section{General methods}

NMR

H NMR spectral data were recorded on a Bruker 400 NMR spectrometer operating at $400 \mathrm{MHz}$. CDCl3 is deuteriochloroform, DMSO- $d 6$ is hexadeuteriodimethylsulfoxide. Chemical shiftsare given in parts per million (ppm) downfield from the NMR solvent.

\section{Chromatography}

Unless stated otherwise, all chromatography was carried out using silica columns.

\section{LCMS Conditions:}

1) Acidic conditions:

Mobile phase: water containing $0.05 \%$ TFA/ acetonitrile

Column: XBridgeTM C18 30 x 100 mm - 5 microns

Detection: MS and photodiode array detector (PDA)

2) Basic conditions:

Mobile phase: water containing $0.08 \% \mathrm{NH}_{4} \mathrm{HCO}_{3} /$ acetonitrile

Column: XBridgeTM C18 30 x 100 mm - 5 microns;

Detection: MS and photodiode array detector (PDA)

\section{Mass Directed Autopreparation Conditions:}

1) Acidic conditions:

Instrument:Waters instrument

Column:Sunfire Prep C18 column (5 um, 19 x 50 mm)

Mobile phase: water containing $0.05 \%$ TFA / acetonitrile.

2) Basic conditions:

Instrumnet: Waters instrument

Column:Xbridge Prep C18 column (5 um, 19 x $50 \mathrm{~mm}$ )

Mobile phase: water containing $0.04 \%$ ammonia/ acetonitrile.

\section{General Procedures}

\subsection{General synthetic route for urea compounds containing sulfone group}

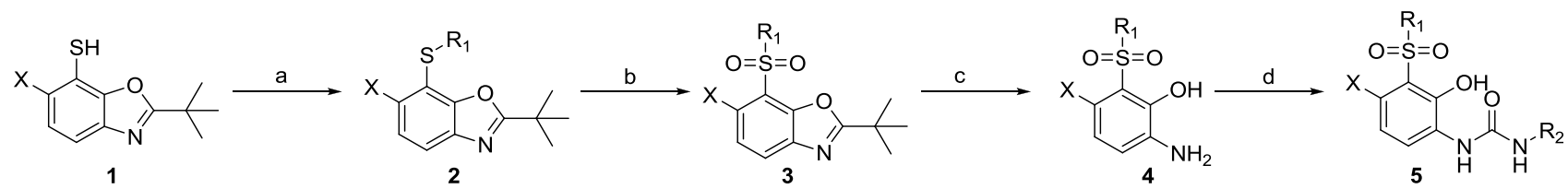

Scheme 1. Synthesis of compounds 1-5. Reagents and conditions: a) $\mathrm{K}_{2} \mathrm{CO}_{3}$, DMF, $\mathrm{R}_{2} \mathrm{X}(\mathrm{X}=\mathrm{Br}$, I), r.t.; b) m-CPBA, DCM, r.t.; c) Conc. $\mathrm{H}_{2} \mathrm{SO}_{4}, 1.4$-dioxane, $100^{\circ} \mathrm{C}$; d)isocyanate, $\mathrm{DMF}$, r.t.

Alkylation of $\mathbf{1}$ is afforded by treatment with R1-LG, where LG denotes a leaving group such as chloro, bromo, iodo or sulfonate, in the presence of base. The resulting sulfides $\mathbf{2}$ are then oxidized to the sulfones $\mathbf{3}$ by using an oxidizing agent such as m-chloroperoxybenzoic acid. Hydrolysis of the benzoxazole moiety yields the aminophenols $\mathbf{4}$ which, in turn, is exposed to an isocyanate or a suitable isocyanate precursor which may be transformed to the isocyanate in situ. This reaction produces the final urea $\mathbf{5}$. 
N-[4-chloro-2-hydroxy-3-(1-piperazinylsulfonyl)phenyl]-N'-(2,3-dichlorophenyl)urea (4)
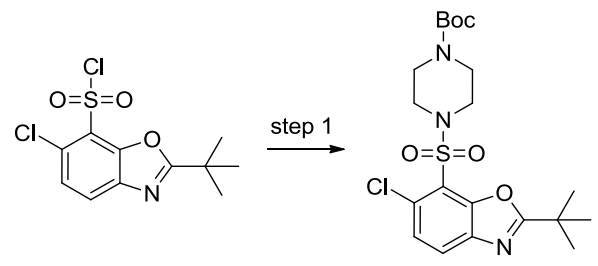

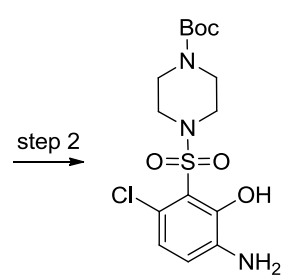

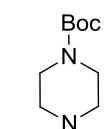
$\stackrel{\text { step } 3}{\longrightarrow}$<smiles>CS(=O)(=O)c1c(Cl)ccc(NC(=O)Nc2cccc(Cl)c2Cl)c1O</smiles>

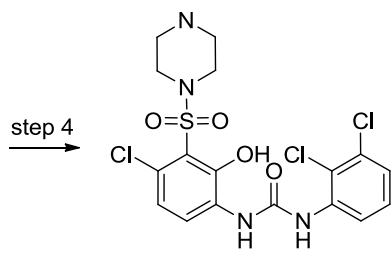

4

Step 1: 1,1-dimethylethyl 4-\{[6-chloro-2-(1,1-dimethylethyl)-1,3-benzoxazol-7-yl]sulfonyl\}-1-piperazinecarboxylate

A solution of 6-chloro-2-(1,1-dimethylethyl)-1,3-benzoxazole-7-sulfonyl chloride (3 g, $9.73 \mathrm{mmol}$ ) and triethylamine (4.07 mL, $29.2 \mathrm{mmol})$ in THF (50 ml) at ice bath temperature was dropwise added 1,1-dimethylethyl 1-piperazinecarboxylate $(1.813 \mathrm{~g}, 9.73 \mathrm{mmol})$. The reaction mixture was stirred at room temperature for $1.5 \mathrm{~h}$. Afterwards, the reaction mixture was concentrated, and partitioned between ethyl acetate $(100 \mathrm{~mL})$ and water $(50 \mathrm{~mL})$. The organic layer was dried over sodium sulfate, filtered, and concentrated in vacuo. The resulting residue was purified by silica gel column chromatography eluting with $20 \%$ - $33 \%$ ethyl acetate in petroleum ether to give 1,1-dimethylethyl

4-\{[6-chloro-2-(1,1-dimethylethyl)-1,3-benzoxazol-7-yl]sulfonyl $\}$-1-piperazinecarboxylate (3 g, $6.22 \mathrm{mmol}, 63.9 \%$ yield) as a brown solid. MS-ESI (m/z): [M+Na $]^{+} 480.2$.

Step 2: 1,1-dimethylethyl 4-[(3-amino-6-chloro-2-hydroxyphenyl)sulfonyl]-1-piperazinecarboxylate

A solution of 1,1-dimethylethyl

4-\{[6-chloro-2-(1,1-dimethylethyl)-1,3-benzoxazol-7-yl]sulfonyl \}-1-piperazinecarboxylate (1.5 g, 3.28 mmol) in 1,4-Dioxane $(20 \mathrm{ml})$ and water $(4 \mathrm{ml})$ was added concentrated $\mathrm{H}_{2} \mathrm{SO}_{4}(2.095 \mathrm{~mL}, 39.3 \mathrm{mmol})$. The mixture was refluxed for $5 \mathrm{~h}$. After cooling to room temperature, the reaction mixture was evaporated in vacuo and adjusted $\mathrm{pH}=12$ by treating with $6 \mathrm{M} \mathrm{NaOH}$. To the above solution was added ethyl acetate $(30 \mathrm{~mL})$ and $(\mathrm{BOC})_{2} \mathrm{O}(0.760 \mathrm{~mL}, 3.28 \mathrm{mmol})$. The mixture was stirred at room temperature overnight. Afterwards, the reaction mixture was partitioned between ethyl acetate $(100 \mathrm{~mL})$ and water $(50 \mathrm{~mL})$. The organic layer was dried over sodium sulfate, and evaporated in vacuo to afford 1,1-dimethylethyl 4-[(3-amino-6-chloro-2-hydroxyphenyl)sulfonyl]-1-piperazinecarboxylate (1.35 g, 2.76 mmol, $84 \%$ yield). MS-ESI (m/z): $[\mathrm{M}+\mathrm{Na}]^{+} 415.1$.

\section{Step 3: 1,1-dimethylethyl}

\section{4-\{[6-chloro-3-(\{[(2,3-dichlorophenyl)amino]carbonyl\}amino)-2-hydroxyphenyl]sulfonyl $\}$-1-piperazinecarboxylate}

To a solution of 1,1-dimethylethyl 4-[(3-amino-6-chloro-2-hydroxyphenyl)sulfonyl]-1-piperazinecarboxylate (0.8 g, 2.041 $\mathrm{mmol})$ in DMF $(15 \mathrm{~mL})$ was added 1,2-dichloro-3-isocyanatobenzene $(0.302 \mathrm{~mL}, 2.246 \mathrm{mmol})$. The reaction mixture was stirred at room temperature for $4 \mathrm{~h}$. Afterwards, the solvent was evporated to give the crude product 1,1-dimethylethyl 4-\{[6-chloro-3-(\{[(2,3-dichlorophenyl)amino]carbonyl $\}$ amino)-2-hydroxyphenyl]sulfonyl $\}$-1-piperazinecarboxylate (1.1 g, $1.897 \mathrm{mmol}, 93 \%$ yield) as a white solid, which was used without further purification. MS-ESI (m/z): [M+Na] 601.0 .

\section{Step 4: N-[4-chloro-2-hydroxy-3-(1-piperazinylsulfonyl)phenyl]-N'-(2,3-dichlorophenyl)urea}

A solution of 1,1-dimethylethyl

4-\{[6-chloro-3-(\{[(2,3-dichlorophenyl)amino]carbonyl $\}$ amino)-2-hydroxyphenyl]sulfonyl $\}$-1-piperazinecarboxylate (1.0 g, $1.724 \mathrm{mmol})$ in TFA $(25 \mathrm{~mL}, 324 \mathrm{mmol})$ was stirred at room temperature for $4 \mathrm{~h}$. Afterwards, the solution was evaporated in vacuo. The resulting residue was purified by Mass Directed Autopreparation to give

N-[4-chloro-2-hydroxy-3-(1-piperazinylsulfonyl)phenyl]-N'-(2,3-dichlorophenyl)urea (600 mg, $1.010 \mathrm{mmol}, 58.6 \%$ yield) as a white solid. ${ }^{1} \mathrm{H}$ NMR (400 MHz, DMSO-d $\left.d_{6}\right) 3.11$ - $3.24(4 \mathrm{H}, \mathrm{m}), 3.44$ - 3.52 (4 H, m), 7.19 (1 H, d, J=8.8 Hz), 7.26 - 7.37 (2 H, m), 8.04 (1 H, dd, J=5.3, $4.5 \mathrm{~Hz}), 8.28$ (1 H, d, J=8.8 Hz), 9.28 (1 H, s), 9.36 (1 H, s). MS-ESI (m/z): $\mathrm{MH}^{+} 479.0$. 

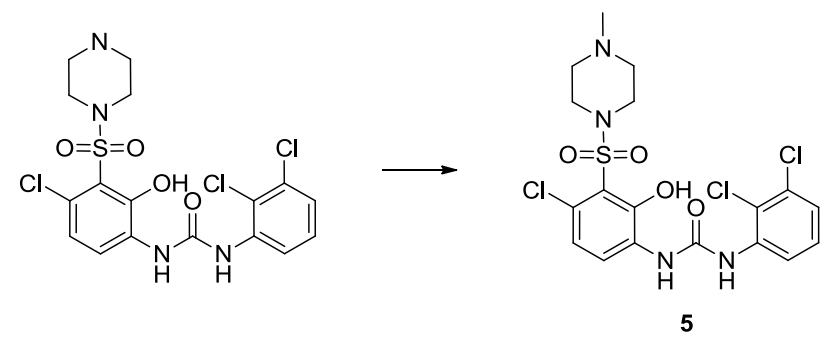

A solution of N-[4-chloro-2-hydroxy-3-(1-piperazinylsulfonyl)phenyl]-N'-(2,3-dichlorophenyl)urea (100 mg, $0.208 \mathrm{mmol})$, paraformaldehyde $(12.52 \mathrm{mg}, 0.417 \mathrm{mmol})$ and acetic acid $(0.012 \mathrm{~mL}, 0.208 \mathrm{mmol})$ in DCM (10 mL) and DMF (1.00 mL) was stirred at room temperature for $15 \mathrm{~min}$. Then sodium triacetoxyborohydride $(66.3 \mathrm{mg}, 0.313 \mathrm{mmol})$ was added to the above solution. The reaction mixture was stirred at room temperature overnight. The reaction mixture was partitioned between $\operatorname{DCM}(30 \mathrm{~mL})$ and saturated sodium bicarbonate solution $(25 \mathrm{~mL})$. The organic layer was washed with water $(25 \mathrm{~mL})$, dried over sodium sulphate, and evaporated in vacuo. The resulting residue purified by Mass Directed Autopreparation to afford N-\{4-chloro-2-hydroxy-3-[(4-methyl-1-piperazinyl)sulfonyl]phenyl\}-N'-(2,3-dichlorophenyl)urea, trifluoroacetic acid (26 mg, $0.042 \mathrm{mmol}, 20.17 \%$ yield). ${ }^{1} \mathrm{H}$ NMR (400 MHz, DMSO- $d_{6}$ ) d ppm $3.02-3.63$ (8 H, m), 7.20 (1 H, d, J=8.8 Hz), 7.27 - 7.37 $(2 \mathrm{H}, \mathrm{m}), 7.99$ - $8.08(1 \mathrm{H}, \mathrm{m}), 8.28(1 \mathrm{H}, \mathrm{d}, J=8.8 \mathrm{~Hz}), 9.27$ (1 H, s), $9.36(1 \mathrm{H}, \mathrm{s}) . \delta \mathrm{F}$ (DMSO- $\left.d_{6}, 376 \mathrm{MHz}\right)$ : -73.6. MS-ESI $(\mathrm{m} / \mathrm{z}): \mathrm{MH}^{+} 493.1$.

\section{N-(2-chloro-3-fluorophenyl)-N'-\{4-chloro-2-hydroxy-3-[(4-methyl-1-piperazinyl)sulfonyl]phenyl\}urea (6)}
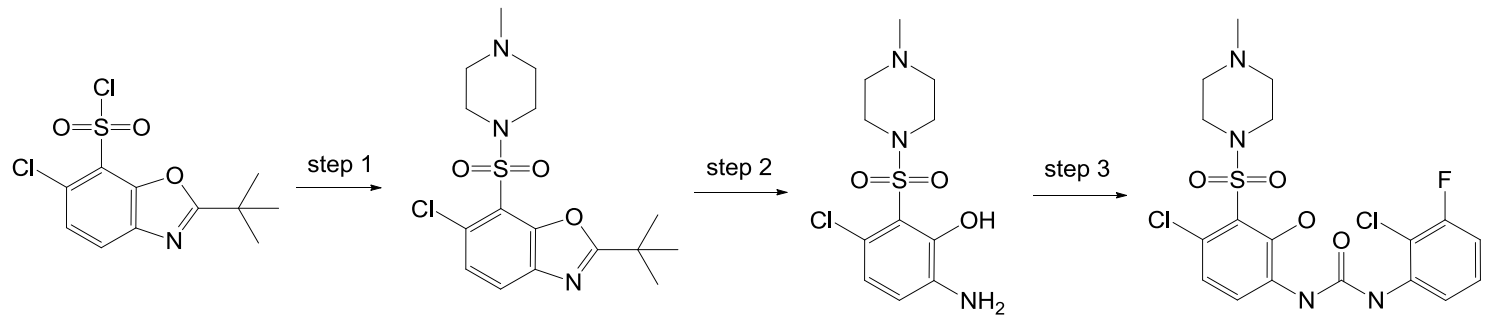

6

Step 1: 6-chloro-2-(1,1-dimethylethyl)-7-[(4-methyl-1-piperazinyl)sulfonyl]-1,3-benzoxazole

A solution of 6-chloro-2-(1,1-dimethylethyl)-1,3-benzoxazole-7-sulfonyl chloride (4.15 g, $13.47 \mathrm{mmol})$ and triethylamine $(5.60 \mathrm{~mL}, 40.4 \mathrm{mmol})$ in THF $(100 \mathrm{ml})$ at ice bath temperature was added 1-methylpiperazine $(1.499 \mathrm{~mL}, 13.47 \mathrm{mmol})$ dropwise. The reaction mixture was stirred at room etmperature for $1.5 \mathrm{~h}$. The reaction mixture was concentrated, and then diluted with water $(50 \mathrm{~mL})$, extracted with ethyl acetate $(2 \times 50 \mathrm{~mL})$. The combined organic layers were dried over sodium sulfate, filtered, and concentrated in vacuo. The resulting residue was purified by silica gel column chromatography eluting with 0-5\% DCM/MeOH to afford 6-chloro-2-(1,1-dimethylethyl)-7-[(4-methyl-1-piperazinyl)sulfonyl]-1,3-benzoxazole (3.5 g, $7.53 \mathrm{mmol}, 55.9 \%$ yield) as a viscous orange oil. MS-ESI (m/z): $\mathrm{MH}^{+} 372.1$.

\section{Step 2: 6-amino-3-chloro-2-[(4-methyl-1-piperazinyl)sulfonyl]phenol}

A solution of 6-chloro-2-(1,1-dimethylethyl)-7-[(4-methyl-1-piperazinyl)sulfonyl]-1,3-benzoxazole (3.5 g, $9.41 \mathrm{mmol})$ in 1,4-Dioxane $(30 \mathrm{ml})$ and water $(6 \mathrm{ml})$ was added concentrated $\mathrm{H}_{2} \mathrm{SO}_{4}(6.02 \mathrm{~mL}, 113 \mathrm{mmol})$. The mixture was refluxed for 2 days. After cooling to room temperature, the solution was adjust to $\mathrm{pH}=14$ by treating with $6 \mathrm{M} \mathrm{NaOH}$. The mixture was partitioned between ethyl acetate $(150 \mathrm{~mL})$ and water $(100 \mathrm{~mL})$. The aqueous phase was extracted with ethyl acetate $(150 \mathrm{~mL})$ again. The combined organic layers were dried over sodium sulfate, filtered, and concentrated in vacuo to afford 6-amino-3-chloro-2-[(4-methyl-1-piperazinyl)sulfonyl]phenol (1.9 g, $4.35 \mathrm{mmol}, 46.2 \%$ yield) as a brown oil. MS-ESI (m/z): $\mathrm{MH}^{+} 306.0$.

Step 3: N-(2-chloro-3-fluorophenyl)-N'-\{4-chloro-2-hydroxy-3-[(4-methyl-1-piperazinyl)sulfonyl]phenyl\}urea 
A solution of 6-amino-3-chloro-2-[(4-methyl-1-piperazinyl)sulfonyl]phenol (212 $\mathrm{mg}, 0.693 \mathrm{mmol})$ and 2-chloro-1-fluoro-3-isocyanatobenzene (264 mg, $0.693 \mathrm{mmol}$ ) in DMF (10 mL) stirred at room temperature for $30 \mathrm{~min}$. The reaction mixture was purified by Mass Directed Autopreparation to afford

$\mathrm{N}$-(2-chloro-3-fluorophenyl)-N'-\{4-chloro-2-hydroxy-3-[(4-methyl-1-piperazinyl)sulfonyl]phenyl\}urea, trifuoroacetic acid salt (163 mg, $0.273 \mathrm{mmol}, 39.4 \%$ yield) as a white solid. ${ }^{1} \mathrm{H}$ NMR (400 MHz, DMSO-d ${ }_{6}$ d ppm 2.83 (5 H, s), 3.28 (7 H, br. s.), 7.03 - $7.13(2 \mathrm{H}, \mathrm{m}), 7.20(2 \mathrm{H}, \mathrm{d}, J=8.8 \mathrm{~Hz}), 7.33(2 \mathrm{H}, \mathrm{td}, J=8.3,6.4 \mathrm{~Hz}), 7.94(2 \mathrm{H}, \mathrm{d}, J=8.5 \mathrm{~Hz}), 8.28(1 \mathrm{H}, \mathrm{d}, J=8.8 \mathrm{~Hz})$, 9.29 (2 H, s), 9.37 (2 H, s), 10.16 (2 H, br. s.). $\delta \mathrm{F}$ (DMSO-d, $376 \mathrm{MHz}):-73.9,-113.7$. MS-ESI (m/z): $\mathrm{MH}^{+} 477.1$.

N-\{4-chloro-3-[(4-ethyl-1-piperazinyl)sulfonyl]-2-hydroxyphenyl\}-N'-(2-chloro-3-fluorophenyl)urea (7)
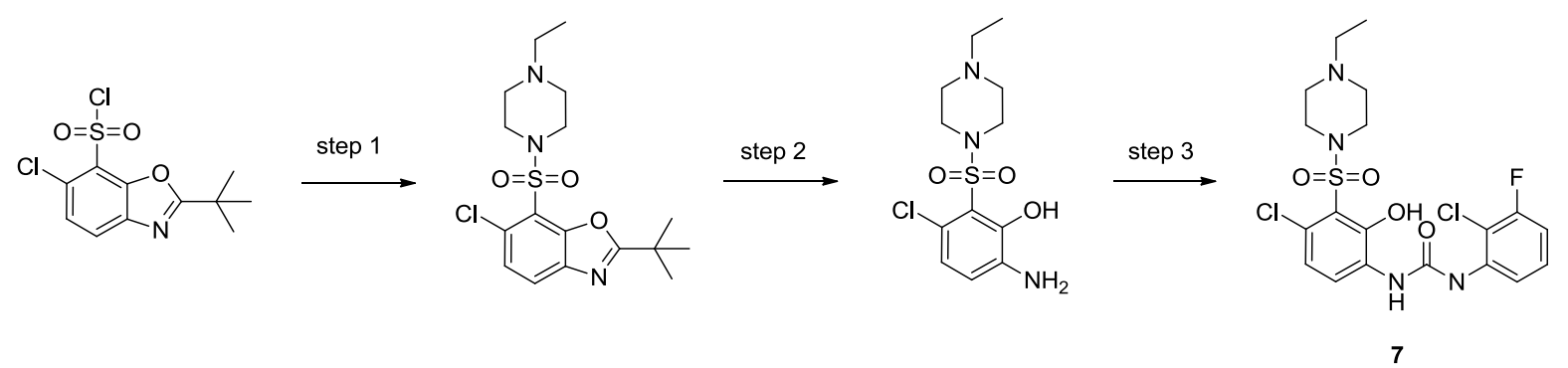

\section{Step1: 6-chloro-2-(1,1-dimethylethyl)-7-[(4-ethyl-1-piperazinyl)sulfonyl]-1,3-benzoxazole}

A solution of 6-chloro-2-(1,1-dimethylethyl)-1,3-benzoxazole-7-sulfonyl chloride (3 g, $9.73 \mathrm{mmol})$ and TEA (4.07 mL, $29.2 \mathrm{mmol}$ ) were diluted in THF (50 ml) under ice bath temperature was dropwise added 1-ethylpiperazine (1.112 g, $9.73 \mathrm{mmol})$ during 2 minutes. The reaction mixture was stirred at room temperature for $1 \mathrm{~h}$. The reaction mixture was concentrated then diluted with water and extracted with ethyl acetate $(50 \mathrm{~mL})$ for twice. The combined organic layers were dried over sodium sulfate, filtered, and concentrated. The resulting residue was purified by silica gel column eluting with $20 \%-33 \%$ ethyl acetate in petroleum ether to afford 6-chloro-2-(1,1-dimethylethyl)-7-[(4-ethyl-1-piperazinyl)sulfonyl]-1,3-benzoxazole (2.3 g, 5.48 $\mathrm{mmol}, 56.3 \%$ yield) as brown viscous liquid. MS-ESI (m/z): $\mathrm{MH}^{+} 386.2$.

\section{Step 2: 6-amino-3-chloro-2-\{[4-(1-methylethyl)-1-piperazinyl]sulfonyl\}phenol}

A solution of 6-chloro-2-(1,1-dimethylethyl)-7-\{[4-ethyl-1-piperazinyl]sulfonyl $\}$-1,3-benzoxazole (2.30 g, $5.96 \mathrm{mmol}) \mathrm{in}$ 1,4-Dioxane $(30 \mathrm{ml})$ and Water $(6 \mathrm{ml})$ was added concentrated $\mathrm{H}_{2} \mathrm{SO}_{4}(3.81 \mathrm{~mL}, 71.5 \mathrm{mmol})$. The reaction mixture was heated to $100{ }^{\circ} \mathrm{C}$ and stirred for overnight. After the solution was cooled to room temperature, The reaction mixture was evaporated in vacuo, then adjusted to $\mathrm{pH}=12$ using $6 \mathrm{M} \mathrm{NaOH}$ solution under ice bath temperature. The mixture was extracted with ethyl acetate $(4 \mathrm{x} \sim 50 \mathrm{~mL})$. The combined organic layers were dried over sodium sulfate, filtered, and concentrated in vacuo to obtain 6-amino-3-chloro-2-[(4-ethyl-1-piperazinyl)sulfonyl]phenol (1.6 g, $4.45 \mathrm{mmol}, 74.7 \%$ yield) as a brown oil. MS-ESI (m/z): $\mathrm{MH}^{+} 320.1$.

\section{Step 3: N-\{4-chloro-3-[(4-ethyl-1-piperazinyl)sulfonyl]-2-hydroxyphenyl\}-N'-(2-chloro-3-fluorophenyl)urea}

A solution of 6-amino-3-chloro-2-[(4-ethyl-1-piperazinyl)sulfonyl]phenol (120 mg, $0.375 \mathrm{mmol})$ and 2-chloro-1-fluoro-3-isocyanatobenzene $(143 \mathrm{mg}, 0.375 \mathrm{mmol}$ in DMF $(5 \mathrm{~mL})$ stirred at room temperature for $30 \mathrm{~min}$. The reaction mixture was purified by Mass Directed Autopreparation directly to afford the product $\mathrm{N}$-\{4-chloro-3-[(4-ethyl-1-piperazinyl)sulfonyl]-2-hydroxyphenyl $\}-\mathrm{N}^{\prime}-(2$-chloro-3-fluorophenyl)urea (103 mg, $0.168 \mathrm{mmol}$, $44.9 \%$ yield) as a white solid. ${ }^{1} \mathrm{H}$ NMR (DMSO- $\left.d_{6}, 400 \mathrm{MHz}\right) 1.18(3 \mathrm{H}, \mathrm{t}, J=7.3 \mathrm{~Hz}), 3.16(3 \mathrm{H}, \mathrm{q}, J=7.1 \mathrm{~Hz}), 7.04-7.13(1 \mathrm{H}$, m), $7.21(1 \mathrm{H}, \mathrm{d}, J=9.0 \mathrm{~Hz}), 7.34(1 \mathrm{H}, \mathrm{td}, J=8.4,6.5 \mathrm{~Hz}), 7.94(1 \mathrm{H}, \mathrm{d}, J=8.5 \mathrm{~Hz}), 8.28(1 \mathrm{H}, \mathrm{d}, J=8.8 \mathrm{~Hz}), 9.28(1 \mathrm{H}, \mathrm{s}), 9.37$ (1 H, s). $\delta$ F (DMSO- $\left.d_{6}, 376 \mathrm{MHz}\right):-73.6,-113.9$. MS-ESI (m/z): $\mathrm{MH}^{+} 491.1$. 

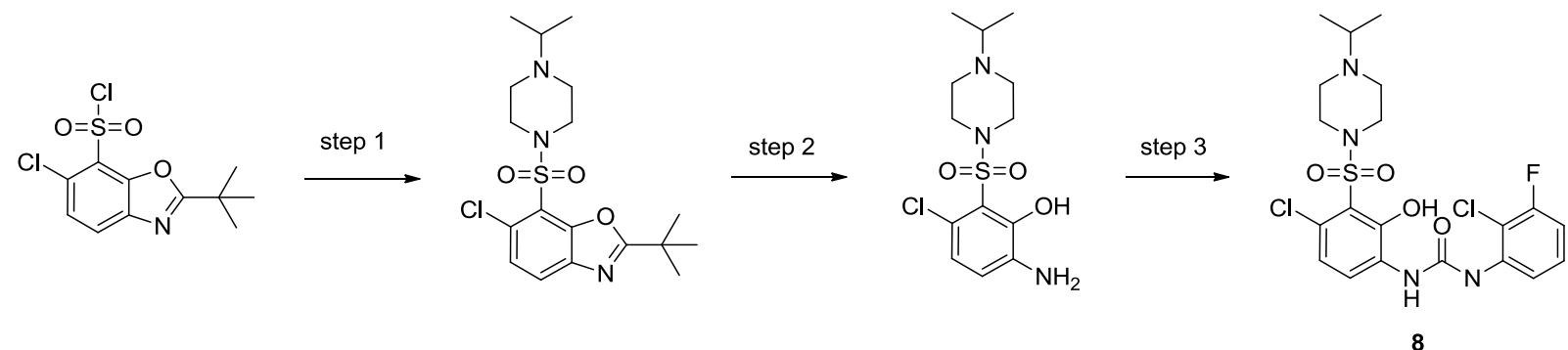

Step 1: 6-chloro-2-(1,1-dimethylethyl)-7-\{[4-(1-methylethyl)-1-piperazinyl]sulfonyl\}-1,3-benzoxazole

A solution of 6-chloro-2-(1,1-dimethylethyl)-1,3-benzoxazole-7-sulfonyl chloride (3 g, $9.73 \mathrm{mmol}$ ) and triethylamine (4.07 mL, $29.2 \mathrm{mmol})$ were diluted in THF $(50 \mathrm{ml})$ under ice bath temperature was dropwise added

1-(1-methylethyl)piperazine (1.248 g, $9.73 \mathrm{mmol})$ during 2 minutes. The reaction mixture was stirred at room temperature for $1 \mathrm{~h}$. The reaction mixture was concentrated then diluted with water and extracted with ethyl acetate $(50 \mathrm{~mL})$ for twice. The combined organic layers were dried over sodium sulfate, filtered, and concentrated. The resulting residue was purified by silica gel column eluting with $20 \%-33 \%$ ethyl acetate in petroleum ether to afford

6-chloro-2-(1,1-dimethylethyl)-7-[(4-(1-methylethyl)-1-piperazinyl)sulfonyl]-1,3-benzoxazole (2.7 g, $6.21 \mathrm{mmol}, 63.8 \%$ yield) as brown viscous liquid. MS-ESI (m/z): $\mathrm{MH}^{+} 400.2$.

\section{Step 2: 6-amino-3-chloro-2-\{[4-(1-methylethyl)-1-piperazinyl]sulfonyl\}phenol}

A solution of 6-chloro-2-(1,1-dimethylethyl)-7-\{[4-(1-methylethyl)-1-piperazinyl]sulfonyl \}-1,3-benzoxazole (2.384 g, $5.96 \mathrm{mmol})$ in 1,4-Dioxane $(30 \mathrm{ml})$ and Water $(6 \mathrm{ml})$ was added concentrated $\mathrm{H} 2 \mathrm{SO} 4(3.81 \mathrm{~mL}, 71.5 \mathrm{mmol})$. The reaction mixture was heated to $100{ }^{\circ} \mathrm{C}$ and stirred for overnight. After the solution was cooled to room temperature, The reaction mixture was evaporated in vacuo, then adjusted to $\mathrm{pH}=12$ using $6 \mathrm{M} \mathrm{NaOH}$ solution under ice bath temperature. The mixture was extracted with ethyl acetate $(4 \mathrm{x} \sim 50 \mathrm{~mL})$. The combined organic layers were dried over sodium sulfate, filtered, and concentrated in vacuo to obtain 6-amino-3-chloro-2-\{[4-(1-methylethyl)-1-piperazinyl]sulfonyl \}phenol (2 g, $5.45 \mathrm{mmol}, 91 \%$ yield) as a brown oil. MS-ESI (m/z): $\mathrm{MH}^{+} 334.1$.

Step 3: N-(2-chloro-3-fluorophenyl)-N'-(4-chloro-2-hydroxy-3-\{[4-(1-methylethyl)-1-piperazinyl]sulfonyl\}phenyl)urea

To a solution of 6-amino-3-chloro-2-\{[4-(1-methylethyl)-1-piperazinyl]sulfonyl $\}$ phenol (100 mg, $0.300 \mathrm{mmol})$ in DMF (5 $\mathrm{mL}$ ) was added 2-chloro-1-fluoro-3-isocyanatobenzene (114 mg, $0.300 \mathrm{mmol})$. The reaction mixture was stirred at room temperature for $30 \mathrm{~min}$. The reaction mixture was purified by Mass Directed Autopreparation directly to afford N-(2-chloro-3-fluorophenyl)-N'-(4-chloro-2-hydroxy-3-\{[4-(1-methylethyl)-1-piperazinyl]sulfonyl \}phenyl)urea (66 mg, 0.101 mmol, $33.9 \%$ yield) as a white solid. $\delta \mathrm{H}$ NMR (DMSO- $\left.d_{6}, 400 \mathrm{MHz}\right) 1.21(6 \mathrm{H}, \mathrm{d}, J=6.5 \mathrm{~Hz}), 3.49$ (1 H, m), 7.09 (1 H, t, $J=8.7 \mathrm{~Hz}), 7.21(1 \mathrm{H}, \mathrm{d}, J=8.8 \mathrm{~Hz}), 7.27-7.40(1 \mathrm{H}, \mathrm{m}), 7.94(1 \mathrm{H}, \mathrm{d}, J=8.5 \mathrm{~Hz}), 8.28(1 \mathrm{H}, \mathrm{d}, J=8.8 \mathrm{~Hz}), 9.28$ (1 H, s), 9.37 (1 H, s). $\delta$ F (DMSO- $\left.d_{6}, 376 \mathrm{MHz}\right):-73.6,-113.9$. MS-ESI (m/z): $\mathrm{MH}^{+} 505.1$.

N-(4-chloro-3-\{[(2R,6S)-2,6-dimethyl-4-morpholinyl]sulfonyl\}-2-hydroxyphenyl)-N'-(2-chloro-3-fluorophenyl)urea (9)
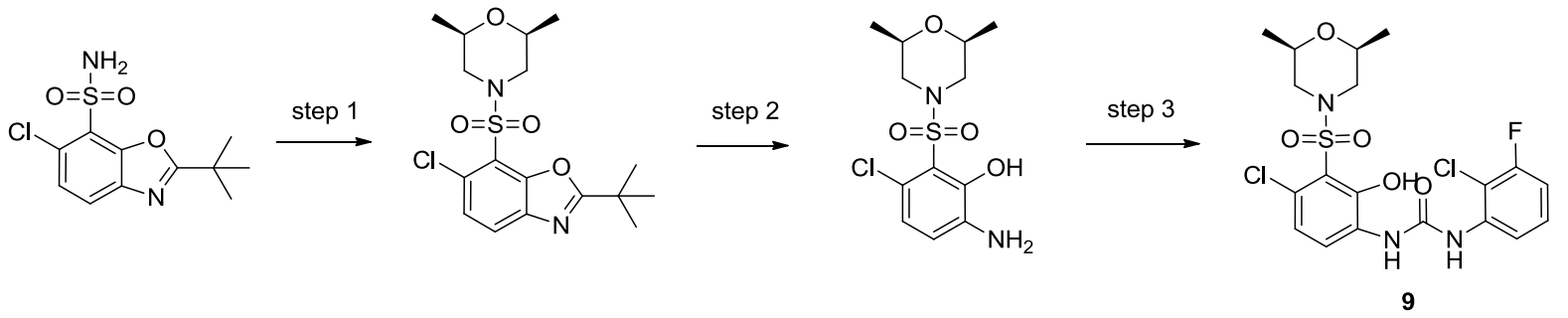

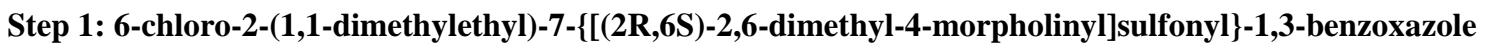

To a solution of 6-chloro-2-(1,1-dimethylethyl)-1,3-benzoxazole-7-sulfonyl chloride ( $2 \mathrm{~g}, 6.49 \mathrm{mmol})$ and triethylamine $(2.71 \mathrm{~mL}, 19.47 \mathrm{mmol})$ in THF $(20 \mathrm{~mL})$ was added $(2 \mathrm{R}, 6 \mathrm{~S})$-2,6-dimethylmorpholine $(0.747 \mathrm{~g}, 6.49 \mathrm{mmol})$. After stirring at room temperature for $2 \mathrm{~h}$, the reaction mixture was concentrated and poured into water $(30 \mathrm{~mL})$. The resulting solution was 
extracted with ethyl acetate $(10 \mathrm{~mL}$, three times). The combined organic layers was dried over sodium sulfate, filtered, and concentrated in vacuo. The resulting residue was purified by silica gel column chromatography eluting with $20 \%$ ethyl acetate in hexane to afford 6-chloro-2-(1,1-dimethylethyl)-7-\{[(2R,6S)-2,6-dimethyl-4-morpholinyl]sulfonyl $\}$-1,3-benzoxazole (1.8 g, $4.37 \mathrm{mmol}, 67.4 \%$ yield) as a white solid. MS-ESI (m/z): $\mathrm{MH}^{+} 387.2$.

\section{Step 2: 6-amino-3-chloro-2-(((2S,6R)-2,6-dimethylmorpholino)sulfonyl)phenol}

To a solution of 6-chloro-2-(1,1-dimethylethyl)-7-\{[(2R,6S)-2,6-dimethyl-4-morpholinyl]sulfonyl $\}$-1,3-benzoxazole (1.8 g, $4.65 \mathrm{mmol}$ ) 1,4-Dioxane $(20 \mathrm{ml})$ and Water $(4 \mathrm{ml})$ was added concentrated H2SO4 (2.98 mL, $55.8 \mathrm{mmol})$. The reaction mixture was heated to $100{ }^{\circ} \mathrm{C}$ and stirred for overnight. After coolling to room temperature, the mixture was adjusted to $\mathrm{pH}=14 \mathrm{using} 6$ $\mathrm{M} \mathrm{NaOH}$. The resulting solution was extracted with ethyl acetate $(3 \times 50 \mathrm{~mL})$. The combined organic layers were dried over sodium sulfate, filtered, and concentrated in vacuo to obtain 6-amino-3-chloro-2-\{[(2R,6S)-2,6-dimethyl-4-morpholinyl]sulfonyl $\}$ phenol (1.5 g, $4.21 \mathrm{mmol}, 90 \%$ yield) as a brown oil. MS-ESI (m/z): $\mathrm{MH}^{+} 321.0$.

Step 3:

\section{N-(4-chloro-3-\{[(2R,6S)-2,6-dimethyl-4-morpholinyl]sulfonyl\}-2-hydroxyphenyl)-N'-(2-chloro-3-fluorophenyl)urea}

To a solution of 6-amino-3-chloro-2-\{[(2R,6S)-2,6-dimethyl-4-morpholinyl]sulfonyl $\}$ phenol (100 mg, $0.312 \mathrm{mmol})$ and 2-chloro-1-fluoro-3-isocyanatobenzene $(119 \mathrm{mg}, 0.312 \mathrm{mmol})$ in DMF (5 mL) stirred at room temperature for $30 \mathrm{~min}$. The reaction mixture was purified by Mass Directed Autopreparation directly to afford the product

N-(4-chloro-3-\{[(2R,6S)-2,6-dimethyl-4-morpholinyl]sulfonyl \}-2-hydroxyphenyl)-N'-(2-chloro-3-fluorophenyl)urea (58.5 mg, $0.118 \mathrm{mmol}, 37.7 \%$ yield) as a white solid. $\delta \mathrm{H} \mathrm{NMR}\left(400 \mathrm{MHz}, \mathrm{DMSO}-d_{6}\right) 1.08(6 \mathrm{H}, \mathrm{d}, J=6.3 \mathrm{~Hz}), 3.33(\mathrm{~m}, 2 \mathrm{H}), 3.50-3.68$ $(4 \mathrm{H}, \mathrm{m}), 7.03-7.12(1 \mathrm{H}, \mathrm{m}), 7.17(1 \mathrm{H}, \mathrm{d}, J=8.8 \mathrm{~Hz}), 7.33(1 \mathrm{H}, \mathrm{td}, J=8.4,6.5 \mathrm{~Hz}), 7.95(1 \mathrm{H}, \mathrm{d}, J=8.3 \mathrm{~Hz}), 8.30(1 \mathrm{H}, \mathrm{d}$, $J=9.0 \mathrm{~Hz}), 9.27(1 \mathrm{H}, \mathrm{s}), 9.34(1 \mathrm{H}, \mathrm{s}), 10.37$ (1 H, s). $\delta \mathrm{F}$ (DMSO-d, $376 \mathrm{MHz}):-114.0 . \mathrm{MS}-\mathrm{ESI}(\mathrm{m} / \mathrm{z}): \mathrm{MH}^{+} 492.1$.

N-(4-chloro-3-\{[(2R,6S)-2,6-dimethyl-4-morpholinyl]sulfonyl\}-2-hydroxyphenyl)-N'-(2,3-dichlorophenyl)urea (10)<smiles>C[C@H]1CN(S(=O)(=O)c2c(Cl)ccc(N)c2O)C[C@@H](C)O1</smiles><smiles>C[C@H]1CN(S(=O)(=O)c2c(Cl)ccc(NC(=O)Nc3cccc(Cl)c3O)c2Cl)C[C@@H](C)O1</smiles>

10

To a solution of 6-amino-3-chloro-2-\{[(2R,6S)-2,6-dimethyl-4-morpholinyl]sulfonyl $\}$ phenol (100 mg, $0.312 \mathrm{mmol})$ and 1,2-dichloro-3-isocyanatobenzene $(58.6 \mathrm{mg}, 0.312 \mathrm{mmol})$ in DMF $(5 \mathrm{~mL})$ stirred at room temperature for $30 \mathrm{~min}$. The reaction mixture was purified by Mass Directed Autopreparation directly to afford

N-(4-chloro-3-\{[(2R,6S)-2,6-dimethyl-4-morpholinyl]sulfonyl \}-2-hydroxyphenyl)-N'-(2,3-dichlorophenyl)urea (37 mg, 0.069 mmol, $21.97 \%$ yield) as a white solid. $\left.\delta \mathrm{H} \mathrm{NMR} \mathrm{(400} \mathrm{MHz,} \mathrm{DMSO-} d_{6}\right) 1.08$ (6 H, d, J=6.3 Hz), 3.45 (2 H, m), 3.53 - 3.64 (4 H, m), $7.17(1 \mathrm{H}, \mathrm{d}, J=8.8 \mathrm{~Hz}), 7.27$ - $7.37(2 \mathrm{H}, \mathrm{m}), 8.05(1 \mathrm{H}, \mathrm{dd}, J=6.3,3.5 \mathrm{~Hz}), 8.29$ (1 H, d, J=8.8 Hz), 9.27 (1 H, s), $9.34(1 \mathrm{H}$, s), $10.37(1 \mathrm{H}, \mathrm{s})$. MS-ESI (m/z): $\mathrm{MH}^{+}$508.2.

\section{$N$-[4-chloro-3-(ethylsulfonyl)-2-hydroxyphenyl]- $N$ '-(2,3-dichlorophenyl)urea (11)}

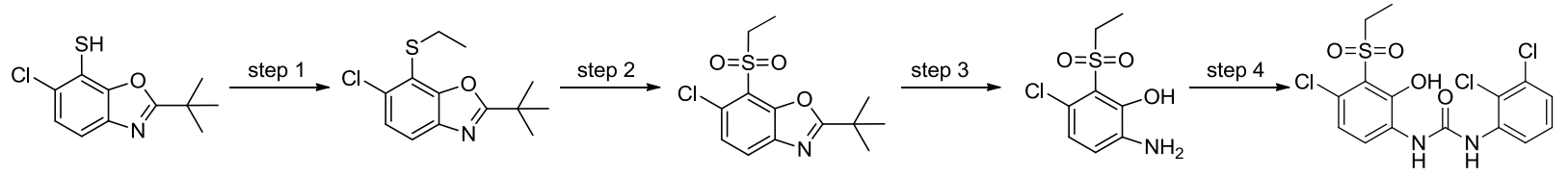




\section{Step 1: 6-chloro-2-(1,1-dimethylethyl)-7-(ethylthio)-1,3-benzoxazole}

To a solution of 6-chloro-2-(1,1-dimethylethyl)-1,3-benzoxazole-7-thiol (5 g) in DMF (50 mL) was added bromoethane (4.51 g) and $\mathrm{K}_{2} \mathrm{CO}_{3}(8.58 \mathrm{~g})$. The mixture was stirred at rt overnight. Afterwards, the solvent was evaporated and the residue was treated with ethyl acetate $(80 \mathrm{~mL})$. The resulting suspension was washed with water $(2 \mathrm{x} 80 \mathrm{~mL})$. The organic phase was dried over andydrous $\mathrm{Na}_{2} \mathrm{SO}_{4}$ and then concentated under vacuo to give the designed product 6-chloro-2-(1,1-dimethylethyl)-7-(ethylthio)-1,3-benzoxazole (4.9 g) as a white solid, which was used for the next step without further purification. $\mathrm{MS}\left(\mathrm{ES}^{+}\right) m / z, 270\left(\mathrm{MH}^{+}\right)$.

\section{Step 2: 6-chloro-2-(1,1-dimethylethyl)-7-(ethylsulfonyl)-1,3-benzoxazole}

To a solution of 6-chloro-2-(1,1-dimethylethyl)-7-(ethylthio)-1,3-benzoxazole (4.9 g) in dichloromethane (DCM) (80 mL) was added m-CPBA $(9.40 \mathrm{~g})$. The mixture was stirred at $\mathrm{rt}$ overnight. The reaction mixture was washed with saturated aqueous $\mathrm{NaHCO}_{3}$ solution $(2 \times 80 \mathrm{~mL})$ and water $(80 \mathrm{~mL})$. The organic phase was dried over anhydrous $\mathrm{Na}_{2} \mathrm{SO}_{4}$ and then concentrated under vacuo to give the designed product 6-chloro-2-(1,1-dimethylethyl)-7-(ethylsulfonyl)-1,3-benzoxazole (4.5 g) as a white solid, which was used for the next step without further purification. $\operatorname{MS}\left(\mathrm{ES}^{+}\right) m / z, 302\left(\mathrm{MH}^{+}\right)$.

\section{Step 3: 6-amino-3-chloro-2-(ethylsulfonyl)phenol}

To a solution of 6-chloro-2-(1,1-dimethylethyl)-7-(ethylsulfonyl)-1,3-benzoxazole (4.5 g) in 1,4-dioxane (60 mL) and water $(12.00 \mathrm{~mL})$ was added $\mathrm{H}_{2} \mathrm{SO}_{4}(4.77 \mathrm{~mL})$ and the mixture was heated to $100^{\circ} \mathrm{C}$ for $48 \mathrm{~h}$. The solvent was partially evaporated and the resulting solution was adjusted to $\mathrm{PH}=14$ by addtion of $6 \mathrm{~N}$ aqueous $\mathrm{NaOH}$. The solution was then extracted with ethyl acetate $(4 * 80 \mathrm{~mL})$ and the combined organic layers were dried over anhydrous $\mathrm{Na}_{2} \mathrm{SO}_{4}$ and concentrated under vacuo to give the designed product 6-amino-3-chloro-2-(ethylsulfonyl)phenol (1.8 g). $\mathrm{MS}\left(\mathrm{ES}^{+}\right) \mathrm{m} / z 236\left(\mathrm{MH}^{+}\right)$.

\section{Step 4: $N$-[4-chloro-3-(ethylsulfonyl)-2-hydroxyphenyl]- $N^{\prime}$-(2,3-dichlorophenyl)urea}

To a solution of 6-amino-3-chloro-2-(ethylsulfonyl)phenol (120 mg) in $N, N$-dimethylformamide (DMF) (10 mL) was added 1,2-dichloro-3-isocyanatobenzene $(144 \mathrm{mg})$. The reaction mixture was stirred at $\mathrm{rt}$ for $4 \mathrm{~h}$. Afterwards, the solution was purified by Mass Directed Autopreparation to give the designed product $N$-[4-chloro-3-(ethylsulfonyl)-2-hydroxyphenyl]- $N$ '-(2,3-dichlorophenyl)urea (50.5 mg). ${ }^{1} \mathrm{H}-\mathrm{NMR}\left(400 \mathrm{MHz}, \mathrm{DMSO}-d_{6}\right) \delta p p m$ 1.22 (t, $J=7.28 \mathrm{~Hz}, 3 \mathrm{H}), 3.69$ (q, J=7.45 Hz, 2H), 7.21 (d, J=8.78 Hz, 1H), 7.33 (m, 2H), 8.07 (dd, J=6.15, 3.64 Hz, 1H), 8.36 (d, $J=9.03 \mathrm{~Hz}, 1 \mathrm{H}), 9.27(\mathrm{~s}, 1 \mathrm{H}), 9.36(\mathrm{~s}, 1 \mathrm{H}), 10.81(\mathrm{~s}, 1 \mathrm{H}) . \mathrm{MS}\left(\mathrm{ES}^{+}\right) \mathrm{m} / z 423\left(\mathrm{MH}^{+}\right)$.

\section{$N$-(2-chloro-3-fluorophenyl)- $N^{\prime}$-\{4-chloro-2-hydroxy-3-[(1-methylethyl)sulfonyl]phenyl\}urea (12)}

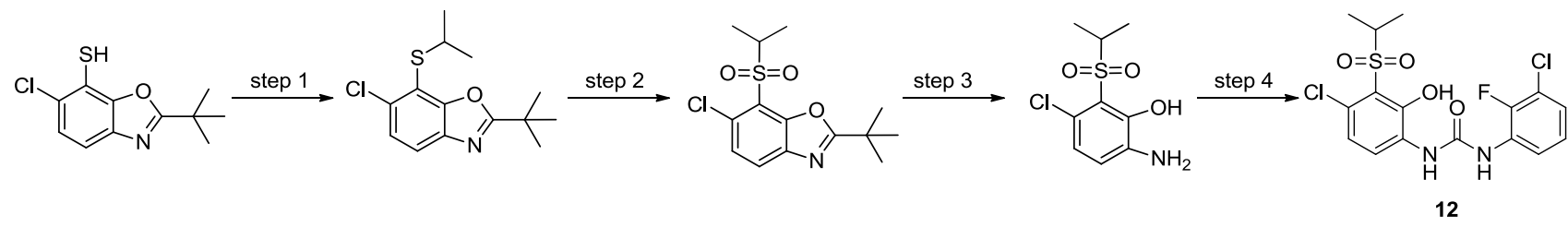

Step 1: 6-chloro-2-(1,1-dimethylethyl)-7-[(1-methylethyl)thio]-1,3-benzoxazole

To a solution of 6-chloro-2-(1,1-dimethylethyl)-1,3-benzoxazole-7-thiol (1.1 g) and 2-bromopropane $(0.641 \mathrm{~mL})$ in $N, N$-Dimethylformamide (DMF) $(25 \mathrm{~mL})$ was added $\mathrm{K}_{2} \mathrm{CO}_{3}(0.943 \mathrm{~g})$. The reaction mixture was stirred at $\mathrm{rt}$ for $4 \mathrm{~h}$. Afterwards, the solvent was evaporated and the residue was redissovled in EA $(50 \mathrm{~mL})$. The organic solution was washed with water $(2 \mathrm{x}$ $50 \mathrm{~mL}$ ) and the organic phase was concentrated in vacuo to give the designed product 6-chloro-2-(1,1-dimethylethyl)-7-[(1-methylethyl)thio]-1,3-benzoxazole $(1.1 \mathrm{~g})$, which was used without further purification.MS(ES $\left.{ }^{+}\right) \mathrm{m} / z$ 284( $\left.\mathrm{MH}^{+}\right)$.

\section{Step 2: 6-chloro-2-(1,1-dimethylethyl)-7-[(1-methylethyl)sulfonyl]-1,3-benzoxazole}

To a solution of 6-chloro-2-(1,1-dimethylethyl)-7-[(1-methylethyl)thio]-1,3-benzoxazole (1.1 g) in dichloromethane (DCM) $(30 \mathrm{~mL})$ was added m-CPBA (1.672 g). The solution was stirred at $\mathrm{rt}$ for $4 \mathrm{~h}$. Afterwards, the solvent was evaporated and the residue was purified by column chroamtography to give the designed product 
6-chloro-2-(1,1-dimethylethyl)-7-[(1-methylethyl)sulfonyl]-1,3-benzoxazole (0.8 g).MS(ES $) \mathrm{m} / \mathrm{z} 316\left(\mathrm{MH}^{+}\right)$.

Step 3: 6-amino-3-chloro-2-[(1-methylethyl)sulfonyl]phenol

To solution of 6-chloro-2-(1,1-dimethylethyl)-7-[(1-methylethyl)sulfonyl]-1,3-benzoxazole (400 mg)in 1,4-dioxane (30 $\mathrm{ml})$ and water $(6 \mathrm{ml})$ was added concentrated $\mathrm{H}_{2} \mathrm{SO}_{4}(0.81 \mathrm{~mL})$, the orange solution is heated to $110^{\circ} \mathrm{C}$ overnight. Reaction mixture was cooled to rt and treated with $6 \mathrm{M} \mathrm{NaOH}$ until $\mathrm{pH}=14$ ( $\mathrm{pH}$ paper). The mixture was extracted with ethyl acetate $(3 \mathrm{x}$ $150 \mathrm{~mL}$ ). The combined organics were dried over sodium sulfate, filtered, and concentrated to give the designed product 6-amino-3-chloro-2-[(1-methylethyl)sulfonyl]phenol $(160 \mathrm{mg})$, which was used without further purification. $\mathrm{MS}\left(\mathrm{ES}^{+}\right) \mathrm{m} / z .250$ $\left(\mathrm{MH}^{+}\right)$.

\section{Step 4: $N$-(2-chloro-3-fluorophenyl)- $N^{\prime}$-\{4-chloro-2-hydroxy-3-[(1-methylethyl)sulfonyl]phenyl\}urea}

To a solution of 6-amino-3-chloro-2-[(1-methylethyl)sulfonyl]phenol (intermediate $6, \quad 120 \quad \mathrm{mg})$ $N, N$-dimethylformamide (DMF) $(10 \mathrm{~mL})$ was added 2-chloro-1-fluoro-3-isocyanatobenzene $(220 \mathrm{mg})$. The reaction mixture was stirred for $3 \mathrm{~h}$. Afterwards, the solution was purified by Mass Directed Autopreparation to give the designed product $N$-(2-chloro-3-fluorophenyl)- $N$ '- $\{$ 4-chloro-2-hydroxy-3-[(1-methylethyl)sulfonyl]phenyl $\}$ urea $(40 \mathrm{mg}) .{ }^{1} \mathrm{H}-\mathrm{NMR}(400 \mathrm{MHz}$, DMSO- $\left.d_{6}\right) \delta$ ppm $1.28(\mathrm{~d}, J=6.78 \mathrm{~Hz}, 6 \mathrm{H}), 3.92(\mathrm{~m}, 1 \mathrm{H}), 7.10(\mathrm{~m}, 2 \mathrm{H}), 7.34(\mathrm{~m}, 1 \mathrm{H}), 7.96(\mathrm{~d}, J=8.53 \mathrm{~Hz}, 1 \mathrm{H}), 8.35(\mathrm{~d}, J=8.78$ $\mathrm{Hz}, 1 \mathrm{H}), 9.28$ (s, 1H), 9.36 (s, 1H), 10.78 (br. s, 1H). ${ }^{19}$ F-NMR $\left(376 \mathrm{MHz}, \mathrm{DMSO}-d_{6}\right):-113.95 . \mathrm{MS}\left(\mathrm{ES}^{+}\right) m / z 421\left(\mathrm{MH}^{+}\right)$.

\section{$N$-\{4-chloro-2-hydroxy-3-[(1-methylethyl)sulfonyl]phenyl\}- $N^{\prime}$-(2,3-dichlorophenyl)urea (13)}
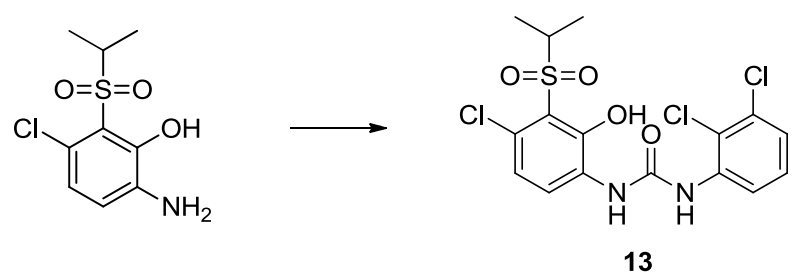

To a solution of 6-amino-3-chloro-2-[(1-methylethyl)sulfonyl]phenol (intermediate 6, $80 \mathrm{mg}$ ) in tetrahydrofuran (THF) $(8 \mathrm{~mL})$ was added 1,2-dichloro-3-isocyanatobenzene $(0.043 \mathrm{~mL})$ and 1,2-dichloro-3-isocyanatobenzene $(0.043 \mathrm{~mL})$. The reaction mixture was stirred for $4 \mathrm{~h}$. Afterwards, the reaction mixture was purified by Mass Directed Autopreparation to give the designed product $N$-\{4-chloro-2-hydroxy-3-[(1-methylethyl)sulfonyl]phenyl $\}$ - $N$ '-(2,3-dichlorophenyl)urea (35 mg). ${ }^{1} \mathrm{H}-\mathrm{NMR}\left(400 \mathrm{MHz}, \mathrm{DMSO}-d_{6}\right) \delta \mathrm{ppm} 1.29(\mathrm{~d}, J=6.78 \mathrm{~Hz}, 6 \mathrm{H}), 3.89(\mathrm{~m}, 1 \mathrm{H}), 7.21(\mathrm{~d}, J=9.03 \mathrm{~Hz}, 1 \mathrm{H}), 7.33(\mathrm{~m}, 2 \mathrm{H}), 8.06$ $(\mathrm{dd}, J=6.02,3.76 \mathrm{~Hz}, 1 \mathrm{H}), 8.38(\mathrm{~d}, J=9.03 \mathrm{~Hz}, 1 \mathrm{H}), 9.28(\mathrm{~s}, 1 \mathrm{H}), 9.36(\mathrm{~s}, 1 \mathrm{H}), 10.78(\mathrm{~s}, 1 \mathrm{H}) . \mathrm{MS}\left(\mathrm{ES}^{+}\right) \mathrm{m} / z, 437\left(\mathrm{MH}^{+}\right)$.

\section{1-(3-(tert-butylsulfonyl)-4-chloro-2-hydroxyphenyl)-3-(2-chloro-3-fluorophenyl)urea (14)}

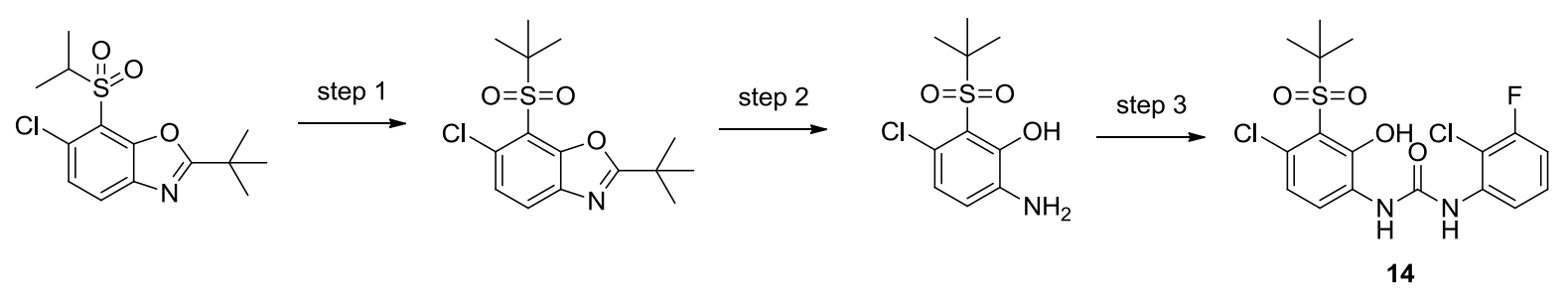

\section{Step 1: 2-(tert-butyl)-7-(tert-butylsulfonyl)-6-chlorobenzo[d]oxazole}

To a solution of 2-(tert-butyl)-6-chloro-7-(isopropylsulfonyl)benzo[d]oxazole (15 g, $47.5 \mathrm{mmol}$ ) in THF (100 mL) was added lithium bis(trimethylsilyl)amide $(95 \mathrm{~mL}, 95 \mathrm{mmol})$ at $-78^{\circ} \mathrm{C}$. After stirring at $-78{ }^{\circ} \mathrm{C}$ for $30 \mathrm{~min} . \mathrm{MeI}(5.94 \mathrm{~mL}, 95 \mathrm{mmol})$ was added to the above solution. The resulting mixture was stirred at this temperature for $3 \mathrm{~h}$. Then, the mixture was quenched with saturated $\mathrm{NH} 4 \mathrm{Cl}$ solution $(10 \mathrm{~mL})$ and partitioned between ethyl acetate $(500 \mathrm{~mL})$ and water $(200 \mathrm{~mL})$. The organic layer was washed with saturated brine, dried over sodium sulfate, and concentrated in vacuo. The resulting residue was purified by 
silica gel column chromatography eluting $10-30 \%$ ethyl acetate in petroleum ether to afford

2-(tert-butyl)-7-(tert-butylsulfonyl)-6-chlorobenzo[d]oxazole (10 g, $30.3 \mathrm{mmol}, 63.8 \%$ yield. MS-ESI (m/z): $\mathrm{MH}^{+} 330.1$.

\section{Step 2: 6-amino-2-(tert-butylsulfonyl)-3-chlorophenol}

To a suspension of 2-(tert-butyl)-7-(tert-butylsulfonyl)-6-chlorobenzo[d]oxazole (10 g, $30.3 \mathrm{mmol}$ ) in 1,4-Dioxane (150 $\mathrm{mL})$ and water $(150 \mathrm{~mL})$ was added $\mathrm{HCl}(61.4 \mathrm{~mL}, 606 \mathrm{mmol})$. The reaction mixture was refluxed for $5 \mathrm{~h}$. Then, the mixture was concentrated under reduced pressure to afford 6-amino-2-(tert-butylsulfonyl)-3-chlorophenol, hydrochloride (8 g, 26.6 mmol, $88 \%$ yield), which used in the next step without purification. MS-ESI (m/z): $\mathrm{MH}^{+}$264.1.

\section{Step 3: 1-(3-(tert-butylsulfonyl)-4-chloro-2-hydroxyphenyl)-3-(2-chloro-3-fluorophenyl)urea}

To a solution of 2-chloro-3-fluoroaniline $(3.88 \mathrm{~g}, 26.6 \mathrm{mmol})$ in DCM $(100 \mathrm{~mL})$, was added triethylamine $(11.14 \mathrm{~mL}, 80$ $\mathrm{mmol}$ ) and bis(trichloromethyl) carbonate $(2.63 \mathrm{~g}, 8.87 \mathrm{mmol})$. The mixture was stirred at room temperature for $10 \mathrm{~min}$ to form solution 1. A solution of 6-amino-2-(tert-butylsulfonyl)-3-chlorophenol, hydrochloride (8 g, $26.6 \mathrm{mmol}$ ) in 1,4-Dioxane (100 $\mathrm{mL})$ and water $(10.00 \mathrm{~mL})$ was added sodium bicarbonate $(6.72 \mathrm{~g}, 80 \mathrm{mmol})$. After stirring at room temperature for $20 \mathrm{~min}$, the fresh prepared solution 1 was added to the above solution. The resulting mixture was stirred for 30 min. The reaction mixture was partitioned between DCM $(150 \mathrm{~mL})$ and water $(100 \mathrm{~mL})$. The organic layer was washed with saturated brine, dried over sodium sulfate, and concentrated in vacuo. The resulting residue was purified by Mass Directed Autopreparation to afford 1-(3-(tert-butylsulfonyl)-4-chloro-2-hydroxyphenyl)-3-(2-chloro-3-fluorophenyl)urea (4.5 g, $10.34 \mathrm{mmol}, 38.8 \%$ yield) as a white solid. ${ }^{1} \mathrm{H}$ NMR (400 MHz, DMF) $1.82(9 \mathrm{H}, \mathrm{s}), 7.46$ - $7.55(1 \mathrm{H}, \mathrm{m}), 7.64(1 \mathrm{H}, \mathrm{d}, J=9.0 \mathrm{~Hz}), 7.77(1 \mathrm{H}, \mathrm{td}, J=8.4,6.5$ Hz), 8.39 (1 H, d, J=8.5 Hz), 8.83 (1 H, d, J=8.8 Hz), 9.71 (1 H, s), 9.79 (1 H, s), 10.94 (1 H, s). $\delta \mathrm{F}(\mathrm{DMF}, 376 \mathrm{MHz}):-113.50$. MS-ESI (m/z): $\mathrm{MH}^{+} 435.1$.

$N$-[4-chloro-3-(cyclobutylsulfonyl)-2-hydroxyphenyl]-N'-(2-chloro-3-fluorophenyl)urea (15)

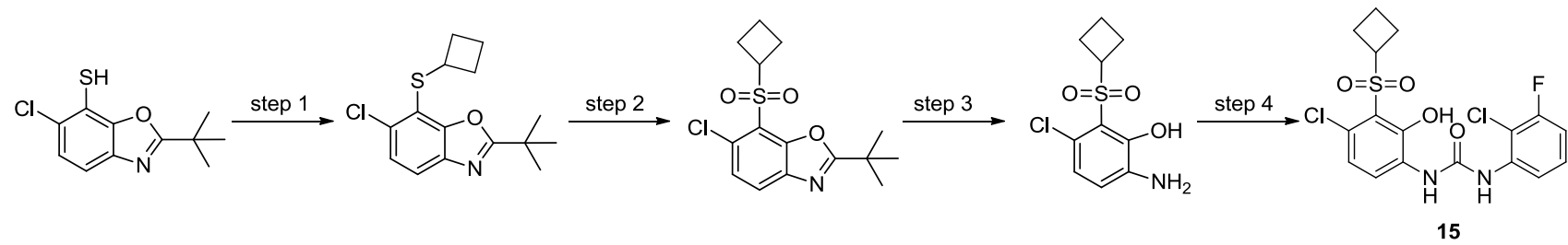

Step 1: 6-chloro-7-(cyclobutylthio)-2-(1,1-dimethylethyl)-1,3-benzoxazole

To a solution of 6-chloro-2-(1,1-dimethylethyl)-1,3-benzoxazole-7-thiol (5 $\mathrm{g})$ in DMF (40 mL) was added bromocyclobutane $(3.89 \mathrm{~mL})$ and $\mathrm{K}_{2} \mathrm{CO}_{3}(2.86 \mathrm{~g})$. The reaction mixture was stirred at $\mathrm{rt}$ ovenight. Afterwards, the solvent was evaporated and the residue was treated with EA $(80 \mathrm{~mL})$. The solution was washed by water $(2 \mathrm{x} 80 \mathrm{ml})$ and the organic layer was then concentrated under vacuo to give the designed product 6-chloro-7-(cyclobutylthio)-2-(1,1-dimethylethyl)-1,3-benzoxazole (5.8 g). MS(ES+) m/z 296 (MH+).

\section{Step 2: 6-chloro-7-(cyclobutylsulfonyl)-2-(1,1-dimethylethyl)-1,3-benzoxazole}

To a solution of 6-chloro-7-(cyclobutylthio)-2-(1,1-dimethylethyl)-1,3-benzoxazole (5.8 g) in dichloromethane (DCM) $(100 \mathrm{~mL})$ was added m-CPBA (8.46 g). The reaction mixture was stirred at rt overnight. Afterwards, the solution was washed with saturated $\mathrm{NaHCO}_{3}(3 \mathrm{x} 80 \mathrm{~mL})$. The organic layer was then dried over anhydrous $\mathrm{Na}_{2} \mathrm{SO}_{4}$ and concentrated under vacuo to give the designed product 6-chloro-7-(cyclobutylsulfonyl)-2-(1,1-dimethylethyl)-1,3-benzoxazole (5.9 g), which was used without further purifaction. $\mathrm{MS}\left(\mathrm{ES}^{+}\right) \mathrm{m} / z 328\left(\mathrm{MH}^{+}\right)$.

\section{Step 3: 6-amino-3-chloro-2-(cyclobutylsulfonyl)phenol}

To a solution of 6-chloro-7-(cyclobutylsulfonyl)-2-(1,1-dimethylethyl)-1,3-benzoxazole (5.9 g) in 1,4-dioxane (60 mL) and water $(12.00 \mathrm{~mL})$ was added $\mathrm{H}_{2} \mathrm{SO}_{4}(11.51 \mathrm{~mL})$. The reaction mixture was heated at $110^{\circ} \mathrm{C}$ for $2 \mathrm{~d}$. Afterwards, the solvent was partially removed and the residue was adjusted to $\mathrm{pH} 14$. The resulting solution was extracted by EA (4 x $80 \mathrm{~mL})$. The combined organic layers was dried over anhydrous $\mathrm{Na}_{2} \mathrm{SO}_{4}$ and concentrated under vacuo to give the designed product 6-amino-3-chloro-2-(cyclobutylsulfonyl)phenol (2.3 g), which was used without further purification. $\left.\mathrm{MS}_{(\mathrm{ES}}^{+}\right) \mathrm{m} / \mathrm{z}, 262\left(\mathrm{MH}^{+}\right)$. 


\section{Step 4: $N$-[4-chloro-3-(cyclobutylsulfonyl)-2-hydroxyphenyl]- $N$ '-(2-chloro-3-fluorophenyl)urea}

To a solution of 6-amino-3-chloro-2-(cyclobutylsulfonyl)phenol (intermediate 3, $140 \mathrm{mg}$ ) in $N$, $N$-dimethylformamide (DMF) (10 mL) was added 2-chloro-1-fluoro-3-isocyanatobenzene (184 mg). The reaction mixture was stirred at $\mathrm{rt}$ for $4 \mathrm{~h}$. Afterwards, the reaction mixture was purified by Mass Directed Autopreparation to give the designed product $N$-[4-chloro-3-(cyclobutylsulfonyl)-2-hydroxyphenyl]- $N$ '-(2-chloro-3-fluorophenyl)urea $\quad(85 \quad \mathrm{mg}) . \quad{ }^{1} \mathrm{H}-\mathrm{NMR} \quad(400 \quad \mathrm{MHz}$, DMSO-d $\left.d_{6}\right) \delta p p m 2.01(\mathrm{~m}, 2 \mathrm{H}), 2.24(\mathrm{~m}, 2 \mathrm{H}), 2.42(\mathrm{~m}, 2 \mathrm{H}), 4.61(\mathrm{~m}, 1 \mathrm{H}), 7.08(\mathrm{~m}, 1 \mathrm{H}), 7.18(\mathrm{~d}, J=8.78 \mathrm{~Hz}, 1 \mathrm{H}), 7.34(\mathrm{~m}, 1 \mathrm{H})$ 7.96 (d, $J=8.53 \mathrm{~Hz}, 1 \mathrm{H}), 8.34$ (d, $J=8.78 \mathrm{~Hz}, 1 \mathrm{H}), 9.27$ (s, 1H), 9.36 (s, 1H), $10.85(\mathrm{~s}, 1 \mathrm{H}) .{ }^{19} \mathrm{~F}-\mathrm{NMR}\left(376 \mathrm{MHz}\right.$,DMSO- $\left.d_{6}\right)$ : -113.94.MS(ES $) m / z$ 433( $\left.\mathrm{MH}^{+}\right)$.

\section{$N$-[4-chloro-3-(cyclopentylsulfonyl)-2-hydroxyphenyl]- $N^{\prime}$-(2-chloro-3-fluorophenyl)urea (16)}

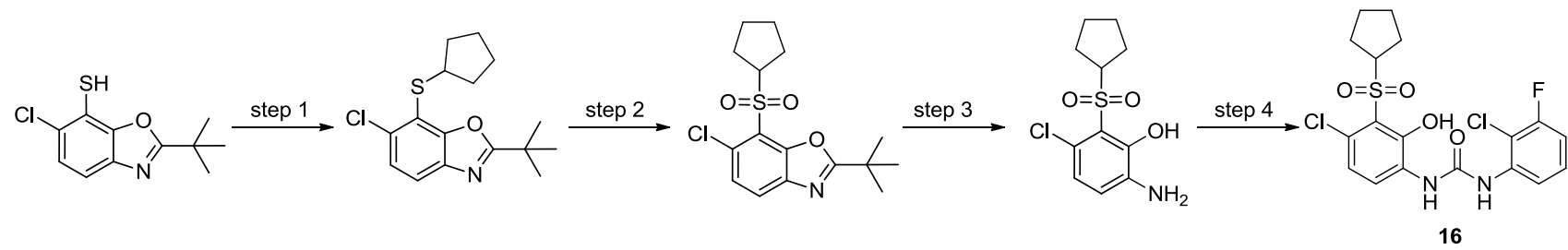

Step 1: 6-chloro-7-(cyclopentylthio)-2-(1,1-dimethylethyl)-1,3-benzoxazole

To a solution of 6-chloro-2-(1,1-dimethylethyl)-1,3-benzoxazole-7-thiol (5 g) in $N, N$-dimethylformamide (DMF) (40 $\mathrm{mL})$ was added iodocyclopentane $(4.78 \mathrm{~mL})$ and $\mathrm{K}_{2} \mathrm{CO}_{3}(8.58 \mathrm{~g})$. The reaction mixture was stirred at rt overnight. Afterwards, the solvent was evaporated and the residue was dissolved in ethyl acetate $(60 \mathrm{~mL})$. The resulting solution was washed with water $(2 \mathrm{x}$ 60mL). The organic phase was then concentrated to afford the designed product 6-chloro-7-(cyclopentylthio)-2-(1,1-dimethylethyl)-1,3-benzoxazole (5.8 g). The compound was used without further purifcation. $\mathrm{MS}\left(\mathrm{ES}^{+}\right) \mathrm{m} / z 310\left(\mathrm{MH}^{+}\right)$.

\section{Step 2: 6-chloro-7-(cyclopentylsulfonyl)-2-(1,1-dimethylethyl)-1,3-benzoxazole}

To a solution of 6-chloro-7-(cyclopentylthio)-2-(1,1-dimethylethyl)-1,3-benzoxazole (5.8 g) in dichloromethane (DCM) $(100 \mathrm{~mL})$ was added m-CPBA $(1.615 \mathrm{~g})$. The reaction mixture was stirred at rt overnight and washed with saturated $\mathrm{NaHCO}_{3}(2$ $\mathrm{x} 100 \mathrm{~mL})$ and then water $(100 \mathrm{~mL})$. The organic phase was dried over anhydrous $\mathrm{Na}_{2} \mathrm{SO}_{4}$ and then concentrated under vacuo to give the crude product 6-chloro-7-(cyclopentylsulfonyl)-2-(1,1-dimethylethyl)-1,3-benzoxazole (5.5 g). The compound was used for the next step without further purification. MS $\left(\mathrm{ES}^{+}\right) \mathrm{m} / z 342\left(\mathrm{MH}^{+}\right)$.

\section{Step 3: 6-amino-3-chloro-2-(cyclopentylsulfonyl)phenol}

To a solution of 6-chloro-7-(cyclopentylsulfonyl)-2-(1,1-dimethylethyl)-1,3-benzoxazole $(5.5 \mathrm{~g})$ in 1,4-dioxane (60 mL) and water $(12.00 \mathrm{~mL})$ was added $\mathrm{H}_{2} \mathrm{SO}_{4}(10.29 \mathrm{~mL})$. The reaction mixture was heated at $100^{\circ} \mathrm{C}$ for $48 \mathrm{~h}$. Afterwards, the solvent was partially removed and the solution was adjusted to $\mathrm{pH}=14$ by addition of $6 \mathrm{~N}$ aqueous $\mathrm{NaOH}$. The resulting solution was extracted with ethyl acetate $(4 \times 80 \mathrm{~mL})$ and the combined organic layers were dried over anhydrous $\mathrm{Na}_{2} \mathrm{SO}_{4}$ and then concentrated under vacuo to give the product 6-amino-3-chloro-2-(cyclopentylsulfonyl)phenol (2.6 g). MS(ES $\left.{ }^{+}\right) \mathrm{m} / z, 276$ $\left(\mathrm{MH}^{+}\right)$.

\section{Step 4: $N$-[4-chloro-3-(cyclopentylsulfonyl)-2-hydroxyphenyl]- $N$ '-(2-chloro-3-fluorophenyl)urea}

To a solution of 6-amino-3-chloro-2-(cyclopentylsulfonyl)phenol (intermediate 1, $170 \mathrm{mg}$ ) in $N, N$-dimethylformamide (DMF) (10 mL) was added 2-chloro-1-fluoro-3-isocyanatobenzene $(212 \mathrm{mg})$. The reaction mixture was stirred at $\mathrm{rt}$ for $4 \mathrm{~h}$. Afterwards, the solution was purified by Mass Directed Autopreparation to give the designed product $N$-[4-chloro-3-(cyclopentylsulfonyl)-2-hydroxyphenyl]- $N$ '-(2-chloro-3-fluorophenyl)urea (33.5 mg). ${ }^{1} \mathrm{H}-\mathrm{NMR}$ (400 MHz, DMSO- $\left.d_{6}\right) \delta p p m 1.70(\mathrm{~m}, 4 \mathrm{H}), 1.91(\mathrm{~m}, 4 \mathrm{H}), 4.26(\mathrm{~m}, 1 \mathrm{H}), 7.09(\mathrm{~m}, 1 \mathrm{H}), 7.21(\mathrm{~d}, J=8.78 \mathrm{~Hz}, 1 \mathrm{H}), 7.34(\mathrm{td}, J=8.28,6.53 \mathrm{~Hz}$, $1 \mathrm{H}), 7.96(\mathrm{~d}, J=8.53 \mathrm{~Hz}, 1 \mathrm{H}), 8.36$ (d, $J=8.78 \mathrm{~Hz}, 1 \mathrm{H}), 9.27$ (s, 1H), 9.36 (s, 1H), $10.83(\mathrm{~s}, 1 \mathrm{H}) .{ }^{19} \mathrm{~F}-\mathrm{NMR}\left(376 \mathrm{MHz}, \mathrm{DMSO}-d_{6}\right)$ : -113.94. MS(ES $) m / z 447\left(\mathrm{MH}^{+}\right)$ 
$N$-[4-chloro-3-(cyclohexylsulfonyl)-2-hydroxyphenyl]- $N$ '-(2-chloro-3-fluorophenyl)urea (17)

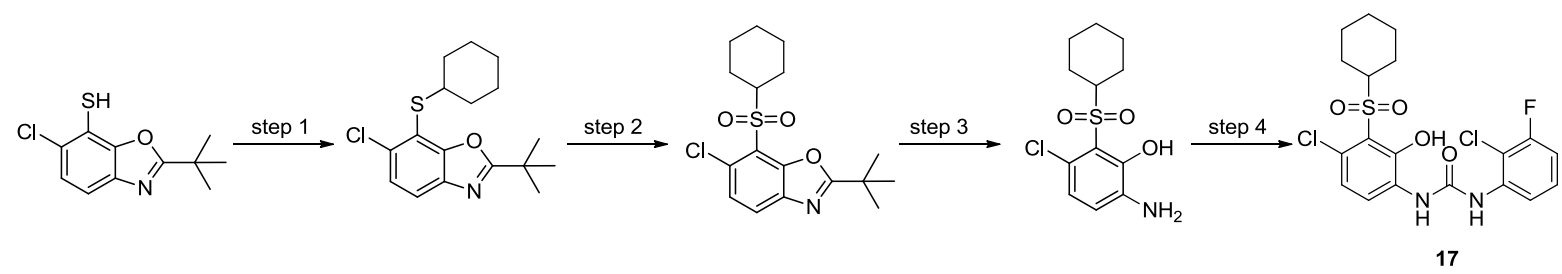

Step 1: 6-chloro-7-(cyclohexylthio)-2-(1,1-dimethylethyl)-1,3-benzoxazole

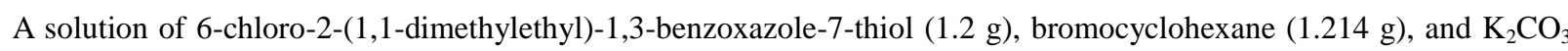
$(1.372 \mathrm{~g})$ was stirred at $\mathrm{rt}$ overnight. Afterwards, the solvent was evaporated and the residue was dissovled in EA (100mL). The resulting solution was washed with water $(2 \times 100 \mathrm{~mL})$. The organic layers was evaporated to give the crude product 6-chloro-7-(cyclohexylthio)-2-(1,1-dimethylethyl)-1,3-benzoxazole $\left(\begin{array}{ll}1.3 & \mathrm{~g}\end{array}\right)$ which was used without further purification.MS(ES $\left.{ }^{+}\right) m / z, 324\left(\mathrm{MH}^{+}\right)$.

\section{Step 2: 6-chloro-7-(cyclohexylsulfonyl)-2-(1,1-dimethylethyl)-1,3-benzoxazole}

To a solution of 6-chloro-7-(cyclohexylthio)-2-(1,1-dimethylethyl)-1,3-benzoxazole (1.3 g) in Dichloromethane (DCM) $(40 \mathrm{~mL})$ was added m-CPBA $(1.039 \mathrm{~g}$,). The reaction was stirred at rt overnight. Afterwards, the solvent was evaporated and the residue was purified by column chromatography to give the designed product 6-chloro-7-(cyclohexylsulfonyl)-2-(1,1-dimethylethyl)-1,3-benzoxazole (1.1 g).MS(ES ${ }^{+} \mathrm{m} / z 356\left(\mathrm{MH}^{+}\right)$.

\section{Step 3: 6-amino-3-chloro-2-(cyclohexylsulfonyl)phenol}

To a solution of 6-chloro-7-(cyclohexylsulfonyl)-2-(1,1-dimethylethyl)-1,3-benzoxazole (1.1 g) in 1,4-Dioxane (20 mL) and water $(4.00 \mathrm{~mL})$ was added $\mathrm{H}_{2} \mathrm{SO}_{4}(1.977 \mathrm{~mL})$. The reaction mixture was then heated to $100^{\circ} \mathrm{C}$ for $2 \mathrm{~d}$. Afterwards, part of the solvent was evaporated and the remaining solution was adjusted to $\mathrm{pH} 14$ by addition of $6 \mathrm{~N} \mathrm{NaOH}$. The resulting solution was extracted with EA $(5 * 50 \mathrm{~mL})$. The combined organic layers were dried over anhydrous $\mathrm{Na}_{2} \mathrm{SO}_{4}$ and then concentrated under vacuo to give the designed product 6-amino-3-chloro-2-(cyclohexylsulfonyl)phenol (0.5 g), which was used without further purification. $\mathrm{MS}\left(\mathrm{ES}^{+}\right) \mathrm{m} / z, 290\left(\mathrm{MH}^{+}\right)$.

\section{Step 4: $N$-[4-chloro-3-(cyclohexylsulfonyl)-2-hydroxyphenyl]- $N$ '-(2-chloro-3-fluorophenyl)urea}

To a solution of 6-amino-3-chloro-2-(cyclohexylsulfonyl)phenol $(50 \mathrm{mg})$ in DMF $(8 \quad \mathrm{~mL})$ was added 2-chloro-1-fluoro-3-isocyanatobenzene $(89 \mathrm{mg})$. The solution was stirred at room temperature for $4 \mathrm{~h}$. Afterwards, the reaction mixture was purified by Directed AutoPreparation to afford $N$-[4-chloro-3-(cyclohexylsulfonyl)-2-hydroxyphenyl]- $N$ '-(2-chloro-3-fluorophenyl)urea $(12 \mathrm{mg})$ as a white solid. ${ }^{1} \mathrm{H}-\mathrm{NMR}$ (400 MHz, DMSO-d $d_{6}$ Sppm $1.29(\mathrm{~m}, 3 \mathrm{H}), 1.51(\mathrm{~m}, 2 \mathrm{H}), 1.65(\mathrm{~m}, 1 \mathrm{H}), 1.87(\mathrm{~m}, 4 \mathrm{H}), 3.64(\mathrm{~m}, 1 \mathrm{H}), 7.09(\mathrm{~m}, 1 \mathrm{H}), 7.21(\mathrm{~d}$, $J=9.03 \mathrm{~Hz}, 1 \mathrm{H}), 7.34$ (td, $J=8.41,6.53 \mathrm{~Hz}, 1 \mathrm{H}), 7.96$ (d, J=8.53 Hz, 1H), 8.38 (d, J=8.78 Hz, 1H), 9.28 (s, $1 \mathrm{H}), 9.36$ (s, $1 \mathrm{H})$, $10.77(\mathrm{~s}, 1 \mathrm{H}) .{ }^{19} \mathrm{~F}-\mathrm{NMR}\left(376 \mathrm{MHz}, \mathrm{DMSO}-d_{6}\right):-113.94 . \mathrm{MS}\left(\mathrm{ES}^{+}\right) \mathrm{m} / z, 461\left(\mathrm{MH}^{+}\right)$. 

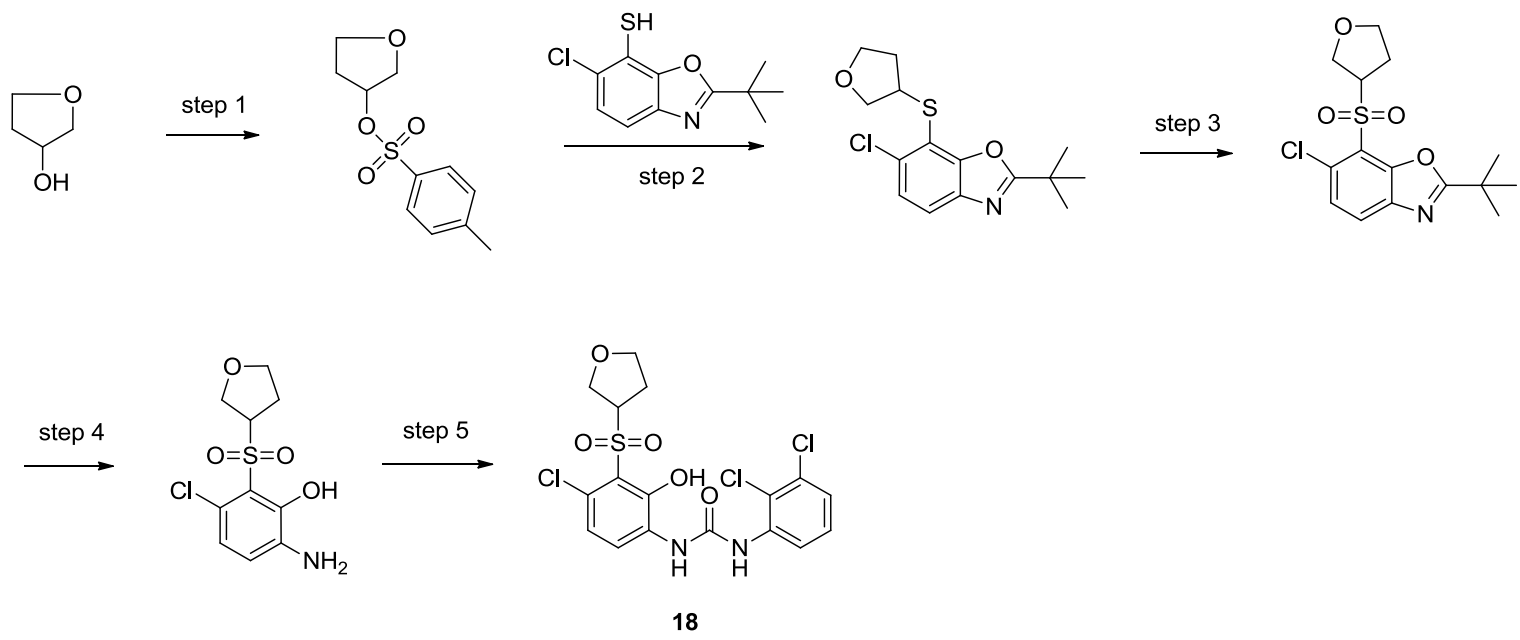

Step 1: tetrahydro-3-furanyl 4-methylbenzenesulfonate

To a solution of tetrahydro-3-furanol $(2.7 \mathrm{~g}, 30.6 \mathrm{mmol})$ in DCM $(60 \mathrm{~mL})$ was added TsCl $(6.43 \mathrm{~g}, 33.7 \mathrm{mmol})$ and triethylamine $(8.54 \mathrm{~mL}, 61.3 \mathrm{mmol})$. The reaction mixture was stirred at room temperature overnight. Afterwards, the solution was washed with water $(50 \mathrm{~mL}$, twice). The combined organic layers were dried over sodium sulfate, filtered and concentrated in vacuo to afford tetrahydro-3-furanyl 4-methylbenzenesulfonate $(6.1 \mathrm{~g}, 25.2 \mathrm{mmol}, 82 \%$ yield $)$ as a white solid without further purifiaction. MS-ESI (m/z): $\mathrm{MH}^{+}$243.0.

\section{Step 2: 2-(tert-butyl)-6-chloro-7-((tetrahydrofuran-3-yl)thio)benzo[d]oxazole}

To a suspension of $\mathrm{NaH}(1.99 \mathrm{~g}, 49.6 \mathrm{mmol})$ in THF $(50 \mathrm{~mL})$ was added 6-chloro-2-(1,1-dimethylethyl)-1,3-benzoxazole-7-thiol (4 g, $16.55 \mathrm{mmol})$. After stirring for 1 hour, tetrahydro-3-furanyl 4-methylbenzenesulfonate ( $4.01 \mathrm{~g}, 16.55 \mathrm{mmol}$ ) in THF was added to the above solution. The reaction mixture was heated to $80{ }^{\circ} \mathrm{C}$ and stirred overnight. The reaction mixture was cooled down to room temperature and quenched with saturated $\mathrm{NaHCO}_{3}$ solution $(50 \mathrm{~mL})$. The reaction mixture was extracted with DCM $(50 \mathrm{~mL}$, twice). Combined organic layers were dried over soldium sulfate, filtered, and concentrated in vacuo. The resulting residue was purified by silica gel column chromatography eluting with ethyl acetate in petroleum ether to give 6-chloro-2-(1,1-dimethylethyl)-7-(tetrahydro-3-furanylthio)-1,3-benzoxazole (3 g, $9.62 \mathrm{mmol}, 58.1 \%$ yield) as a white solid. MS-ESI (m/z): $\mathrm{MH}^{+} 270.0$.

\section{Step 3: 2-(tert-butyl)-6-chloro-7-((tetrahydrofuran-3-yl)sulfonyl)benzo[d]oxazole}

To a solution of 6-chloro-2-(1,1-dimethylethyl)-7-(tetrahydro-3-furanylthio)-1,3-benzoxazole (3 g, 9.62 mmol) in DCM $(60 \mathrm{~mL})$ was added $\mathrm{m}$-CPBA $(1.743 \mathrm{~g}, 10.10 \mathrm{mmol})$. The reaction mixture was stirred overnight at room temperature.

Afterwards, the solvent was evaporated and the residue was purified by silica gel column chromatography eluting with $0-100 \%$ ethyl acetate in petroleum ether to give 6-chloro-2-(1,1-dimethylethyl)-7-(tetrahydro-3-furanylsulfonyl)-1,3-benzoxazole (2.6 g, $7.56 \mathrm{mmol}, 79 \%$ yield) as a white solid. MS-ESI (m/z): $\mathrm{MH}^{+} 344.1$.

\section{Step 4: 6-amino-3-chloro-2-(tetrahydro-3-furanylsulfonyl)phenol}

To a solution of 6-chloro-2-(1,1-dimethylethyl)-7-(tetrahydro-3-furanylsulfonyl)-1,3-benzoxazole (1.1 g, $3.20 \mathrm{mmol})$ in 1,4-Dioxane $(30 \mathrm{~mL})$ and Water $(6.00 \mathrm{~mL})$ was added $\mathrm{H}_{2} \mathrm{SO}_{4}(2.046 \mathrm{~mL}, 38.4 \mathrm{mmol})$. The reaction mixture was heated to $100{ }^{\circ} \mathrm{C}$ and stirred for 2 days. After cooling to room termperature, the solution was concentrated to remove 1,4-dioxane and the remaining solution was adjusted to $\mathrm{pH}=14$ by addition of $6 \mathrm{~N} \mathrm{NaOH}$. The solution was extracted by ethyl acetate $(60 \mathrm{~mL}$, three times) and the combined organic layers were dried over anhydrous sodium sulfate, filtered, and concentrated to give the crude product 6-amino-3-chloro-2-(tetrahydro-3-furanylsulfonyl)phenol (380 mg, $1.368 \mathrm{mmol}, 42.8 \%$ yield) which was used without further purification. MS-ESI (m/z): $\mathrm{MH}^{+} 278.1$.

Step 5: N-[4-chloro-2-hydroxy-3-(tetrahydro-3-furanylsulfonyl)phenyl]-N'-(2,3-dichlorophenyl)urea 
A solution of 6-amino-3-chloro-2-(tetrahydro-3-furanylsulfonyl)phenol (120 mg, $0.432 \mathrm{mmol}$ ) and 1,2-dichloro-3-isocyanatobenzene $(0.070 \mathrm{~mL}, 0.518 \mathrm{mmol})$ in DMF $(10 \mathrm{~mL})$ was stirred at room temperature for $4 \mathrm{~h}$. The reaction mixture was directly purified by Mass Directed Autopreparation to give N-[4-chloro-2-hydroxy-3-(tetrahydro-3-furanylsulfonyl)phenyl]-N'-(2,3-dichlorophenyl)urea (45 mg, 0.097 mmol, $22.36 \%$ yield) as a white solid. $\delta \mathrm{H}$ NMR (400 MHz, DMSO- $\left.d_{6}\right) 2.15$ - $2.34(2 \mathrm{H}, \mathrm{m}), 3.61$ - $3.74(1 \mathrm{H}, \mathrm{m}), 3.87$ - 3.98 (2 H, m), 4.06 (1 H, dd, J=10.3, 4.0 Hz), 4.54 - $4.66(1 \mathrm{H}, \mathrm{m}), 7.22(1 \mathrm{H}, \mathrm{d}, J=8.8 \mathrm{~Hz}), 7.28$ - 7.37 (2 H, m), 7.99 - 8.10 (1 H, m), 8.35 (1 H, d, $J=9.0 \mathrm{~Hz}), 9.27(1 \mathrm{H}, \mathrm{s}), 9.36(1 \mathrm{H}, \mathrm{s}), 10.70(1 \mathrm{H}, \mathrm{s})$. MS-ESI $(\mathrm{m} / \mathrm{z}): \mathrm{MH}^{+} 465.0$.

N-[4-chloro-2-hydroxy-3-(tetrahydro-2H-pyran-4-ylsulfonyl)phenyl]-N'-(2,3-dichlorophenyl)urea (19)
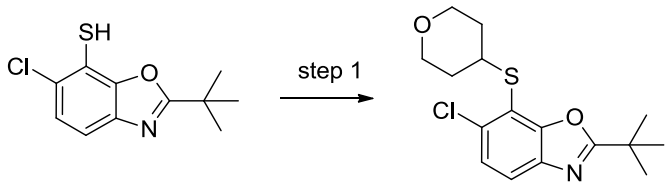

step 2

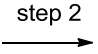

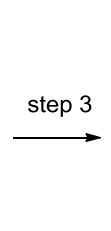
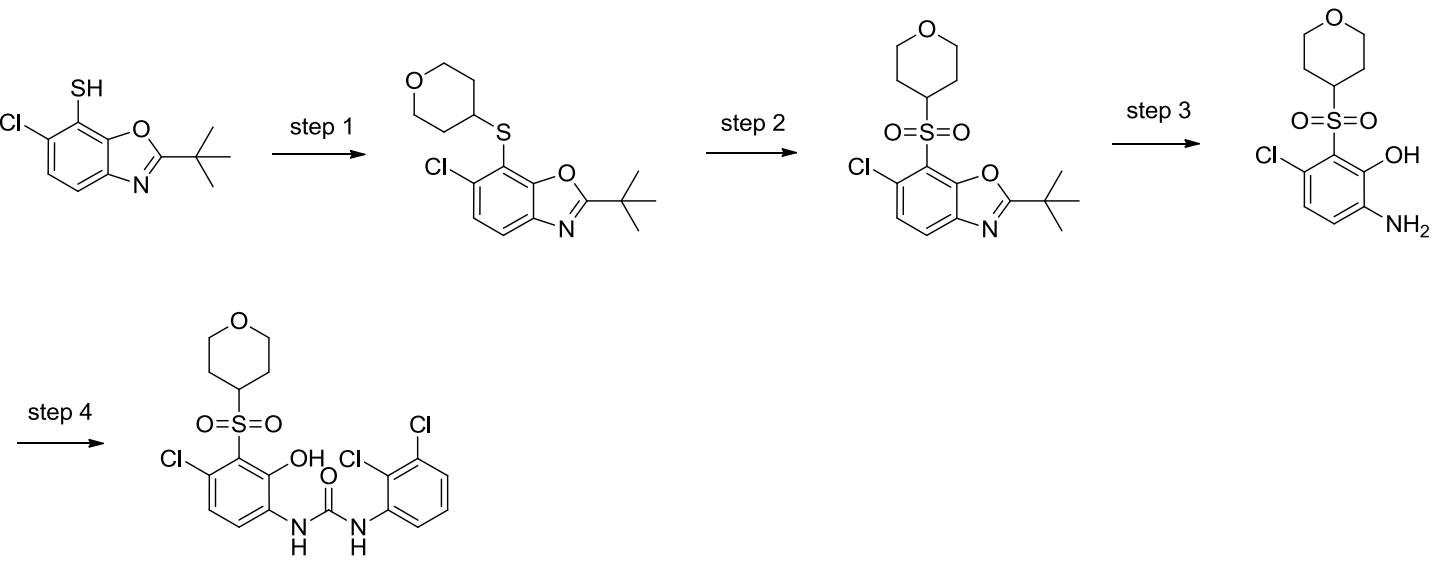

19

\section{Step 1: 6-chloro-2-(1,1-dimethylethyl)-7-(tetrahydro-2H-pyran-4-ylthio)-1,3-benzoxazole}

To a solution of 6-chloro-2-(1,1-dimethylethyl)-1,3-benzoxazole-7-thiol (3 g, $12.41 \mathrm{mmol})$ in DMF (35 mL) was added 4-bromotetrahydro-2H-pyran (2.048 g, $12.41 \mathrm{mmol})$ and $\mathrm{K}_{2} \mathrm{CO}_{3}(3.43 \mathrm{~g}, 24.82 \mathrm{mmol})$. The reaction mixture was stirred at room temperature overnight. The reaction mixture was diluted with ethyl acetate $(100 \mathrm{~mL})$ and the solution was washed with saturated brine $(60 \mathrm{~mL}$, three times). The organic layer was dried over anhydrous sodium sulfate, filtered, and concentrated in vacuo to give 6-chloro-2-(1,1-dimethylethyl)-7-(tetrahydro-2H-pyran-4-ylthio)-1,3-benzoxazole (3.2 g, $9.82 \mathrm{mmol}, 79 \%$ yield) as a white solid. MS-ESI (m/z): $\mathrm{MH}^{+} 326.1$.

\section{Step 2: 6-chloro-2-(1,1-dimethylethyl)-7-(tetrahydro-2H-pyran-4-ylsulfonyl)-1,3-benzoxazole}

To a solution of 6-chloro-2-(1,1-dimethylethyl)-7-(tetrahydro-2H-pyran-4-ylthio)-1,3-benzoxazole (3.2 g, $9.82 \mathrm{mmol})$ in DCM $(50 \mathrm{~mL})$ was added m-CPBA $(2.54 \mathrm{~g}, 14.73 \mathrm{mmol})$. The reaction mixture was stirred at room temperature overnight. The reaction mixture was quenched with saturated $\mathrm{NaHCO}_{3}$ solution $(30 \mathrm{~mL})$, and extracted with DCM $(50 \mathrm{~mL}$, twice). The combined organic layers were dried over sodium sulfate, filtered and concentrated in vacuo. The resulting residue was purified by silica gel column chromatography eluting with $0-100 \%$ ethyl acetate in petroleum ether to give 6-chloro-2-(1,1-dimethylethyl)-7-(tetrahydro-2H-pyran-4-ylsulfonyl)-1,3-benzoxazole (2.1 g, $5.87 \mathrm{mmol}, 59.8 \%$ yield). MS-ESI (m/z): $\mathrm{MH}^{+} 358.0$.

\section{Step 3: 6-amino-3-chloro-2-(tetrahydro-2H-pyran-4-ylsulfonyl)phenol}

To a solution of 6-chloro-2-(1,1-dimethylethyl)-7-(tetrahydro-2H-pyran-4-ylsulfonyl)-1,3-benzoxazole (2.5 g, $6.99 \mathrm{mmol})$ in 1,4-Dioxane $(40 \mathrm{~mL})$ and Water $(8.00 \mathrm{~mL})$ was added $\mathrm{H} 2 \mathrm{SO} 4(4.47 \mathrm{~mL}, 84 \mathrm{mmol})$. The reaction mixture was heated to $100{ }^{\circ} \mathrm{C}$ and stirred for 2 days. Afterwards, the solvent was partially evaporated and the residue was adjusted to $\mathrm{pH} 14$ by the addition of $6 \mathrm{~N} \mathrm{NaOH}$. The resulting solution was extracted by ethyl acetate $(80 \mathrm{~mL}$, three times). The combined organic layers were dried over anhydrous sodium sulfate, filtered, and concentated in vacuo to give 6-amino-3-chloro-2-(tetrahydro-2H-pyran-4-ylsulfonyl)phenol (1.3 g, $4.46 \mathrm{mmol}, 63.8 \%$ yield) as a white solid without further purification. MS-ESI (m/z): $[\mathrm{M}+\mathrm{Na}]^{+} 292.0$. 
Step 4: N-[4-chloro-2-hydroxy-3-(tetrahydro-2H-pyran-4-ylsulfonyl)phenyl]-N'-(2,3-dichlorophenyl)urea

A solution of 6-amino-3-chloro-2-(tetrahydro-2H-pyran-4-ylsulfonyl)phenol (100 mg, $0.343 \mathrm{mmol})$ and 1,2-dichloro-3-isocyanatobenzene $(0.055 \mathrm{~mL}, 0.411 \mathrm{mmol})$ in DMF $(10 \mathrm{~mL})$ was stirred at room temperature for $4 \mathrm{~h}$. The reaction mixture was directly purified by Mass Directed Autopreparation to give

N-[4-chloro-2-hydroxy-3-(tetrahydro-2H-pyran-4-ylsulfonyl)phenyl]-N'-(2,3-dichlorophenyl)urea (16 mg, $0.033 \mathrm{mmol}, 9.7 \%$ yield) as a white solid. $\delta \mathrm{H}$ NMR (400 MHz, DMSO- $\left.d_{6}\right) 1.65$ - $1.84(4 \mathrm{H}, \mathrm{m}), 3.35$ - $3.43(2 \mathrm{H}, \mathrm{m}), 3.86$ - $4.03(3 \mathrm{H}, \mathrm{m}), 7.21(1$ $\mathrm{H}, \mathrm{d}, J=8.8 \mathrm{~Hz}), 7.28$ - 7.35 (2 H, m), 8.05 (1 H, dd, J=5.9, $3.9 \mathrm{~Hz}), 8.37$ (1 H, d, J=8.8 Hz), 9.23 - 9.30 (1 H, m), 9.35 (1 H, s), $10.68(1 \mathrm{H}, \mathrm{s})$. MS-ESI (m/z): [M+Na $]^{+} 500.9$.

\section{1-[4-chloro-2-hydroxy-3-(piperidine-4-sulfonyl)-phenyl]-3-(2,3-dichloro-phenyl)-urea (20)}
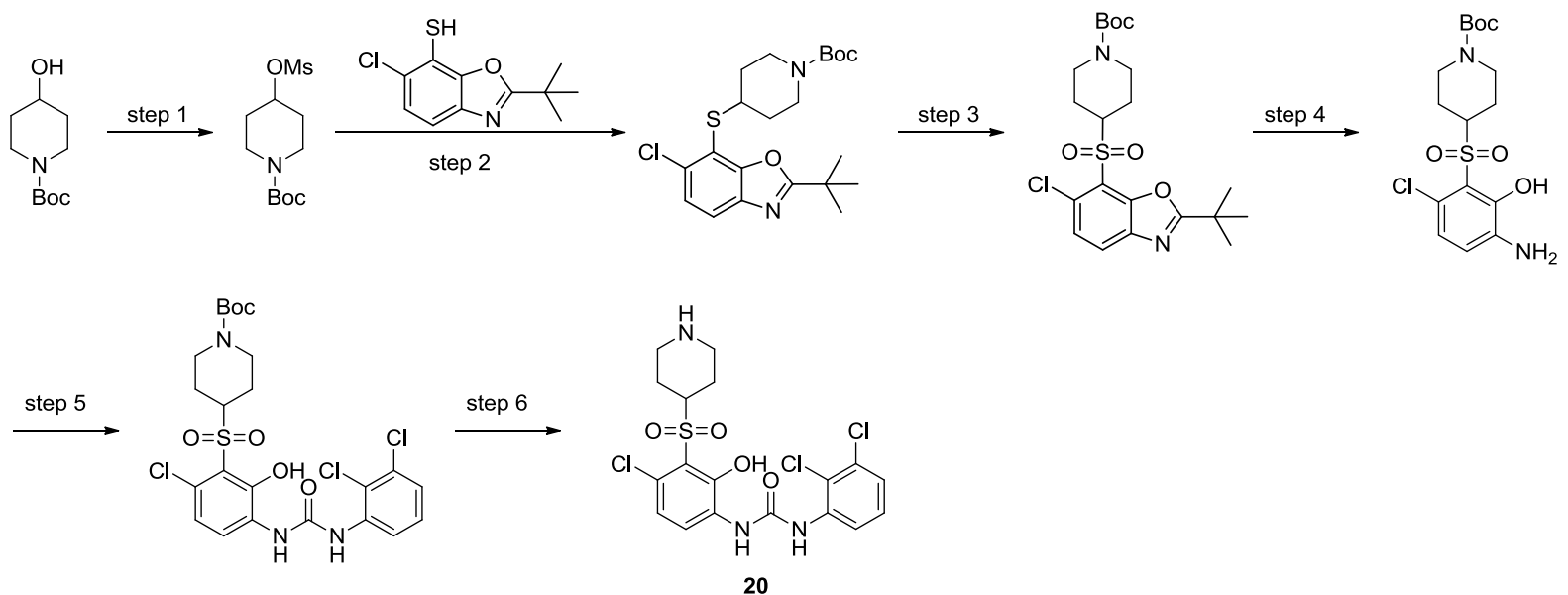

Step 1: 1,1-dimethylethyl 4-[(methylsulfonyl)oxy]-1-piperidinecarboxylate

To a solution of 1,1-dimethylethyl 4-hydroxy-1-piperidinecarboxylate $(6.0 \mathrm{~g}, 29.8 \mathrm{mmol})$ in DCM $(50 \mathrm{~mL})$ was added TEA $(8.33 \mathrm{~mL}, 59.6 \mathrm{mmol})$ and $\mathrm{MsCl}(2.419 \mathrm{~mL}, 29.8 \mathrm{mmol})$ at $0{ }^{\circ} \mathrm{C}$. The resulting mixture was stirred at this temperature for $1 \mathrm{~h}$. Then the mixture was partitioned between DCM $(40 \mathrm{~mL})$ and saturated $\mathrm{NaHCO}_{3}$ solution $(20 \mathrm{~mL})$. The organic layer was dried over soium sulfate, and concentrated in vacuo to afford 1,1-dimethylethyl 4-[(methylsulfonyl)oxy]-1-piperidinecarboxylate $(8.0 \mathrm{~g}, 28.6 \mathrm{mmol}, 96 \%)$ as a white solid. MS-ESI (m/z): [M+Na $]^{+} 302.0$.

\section{Step 2: 1,1-dimethylethyl 4-\{[6-chloro-2-(1,1-dimethylethyl)-1,3-benzoxazol-7-yl]thio\}-1-piperidinecarboxylate}

To a solution of 6-chloro-2-(1,1-dimethylethyl)-1,3-benzoxazole-7-thiol (7000 mg, $29.0 \mathrm{mmol}$ ) and 1,1-dimethylethyl 4-[(methylsulfonyl)oxy]-1-piperidinecarboxylate $(8089 \mathrm{mg}, 29.0 \mathrm{mmol})$ in $(30 \mathrm{~mL})$ was added $\mathrm{K}_{2} \mathrm{CO}_{3}(4031 \mathrm{mg}, 29.0 \mathrm{mmol})$. The resulting mixture was stirred at $80{ }^{\circ} \mathrm{C}$ overnight. The resulting mixture was partitioned bwtween ethyl acetate $(150 \mathrm{~mL})$ and water $(50 \mathrm{~mL})$. The organic layer was washed with saturated brine $(100 \mathrm{~mL})$, dried over sodium sulfate, and concentrated in vacuo. The resulting residue was purified by silica gel column chromatography eluting with 0-10\% ethyl acetate in petroleum ether to afford 1,1-dimethylethyl 4-\{[6-chloro-2-(1,1-dimethylethyl)-1,3-benzoxazol-7-yl]thio $\}$-1-piperidinecarboxylate (11.8 g, $27.8 \mathrm{mmol}, 96 \%$ yield) as a white solid. MS-ESI (m/z): $[\mathrm{M}+\mathrm{Na}]^{+} 447.1$.

\section{Step 3: 1,1-dimethylethyl 4-\{[6-chloro-2-(1,1-dimethylethyl)-1,3-benzoxazol-7-yl]sulfonyl\}-1-piperidinecarboxylate}

A mixture of 1,1-dimethylethyl 4-\{[6-chloro-2-(1,1-dimethylethyl)-1,3-benzoxazol-7-yl]thio\}-1-piperidinecarboxylate $(11.8 \mathrm{~g}, 27.8 \mathrm{mmol})$ and 3-chlorobenzenecarboperoxoic acid $(12.45 \mathrm{~g}, 55.5 \mathrm{mmol})$ in DCM (100 mL) was stirred at room temperature overnight. The mixure was added aq. $\mathrm{NaHCO}_{3}$ and aq. $\mathrm{Na}_{2} \mathrm{~S}_{2} \mathrm{O}_{3}$, after being stirred at room temperature for 30 min, it was extracted with DCM $(2 \times 150 \mathrm{~mL})$, washed with brine and dried over sodium sulfate. The organic layer was concentrated to afford 1,1-dimethylethyl 4-\{[6-chloro-2-(1,1-dimethylethyl)-1,3-benzoxazol-7-yl]sulfonyl $\}$-1-piperidinecarboxylate (12.7 g, $27.8 \mathrm{mmol}, 100 \%$ yield) as a white solid. MS-ESI (m/z): $[\mathrm{M}+\mathrm{Na}]^{+} 479.0$.

Step 4: tert-butyl 4-((3-amino-6-chloro-2-hydroxyphenyl)sulfonyl)piperidine-1-carboxylate 
To a solution of tert-butyl 4-((2-(tert-butyl)-6-chlorobenzo[d]oxazol-7-yl)sulfonyl)piperidine-1-carboxylate (65 g, 142 $\mathrm{mmol})$ in 1,4-Dioxane $(500 \mathrm{~mL})$ and water $(125 \mathrm{~mL})$ was added $\mathrm{H}_{2} \mathrm{SO}_{4}(60.7 \mathrm{~mL}, 1138 \mathrm{mmol})$. The resulting mixture was stirred at $100{ }^{\circ} \mathrm{C}$ overnight. The mixture was poured on ice and the solution was basified to $\mathrm{pH}=8$ by treating with $2 \mathrm{M} \mathrm{NaOH}$ solution. Then, to the mixture was added $(\mathrm{BOC})_{2} \mathrm{O}(31.0 \mathrm{~g}, 142 \mathrm{mmol})$ dropwise, and the mixture was stirred at room temperature for $2 \mathrm{~h}$. The mixture was partitioned between ethyl acetate $(500 \mathrm{~mL})$ and water $(500 \mathrm{~mL})$. The organic layer was washed with saturated brine $(200 \mathrm{~mL})$, dried over sodium sulfate, and concentrated in vacuo. The resulting residue was purified by silcia gel column chromatography eluting with $10-40 \%$ ethyl acetate in to afford tert-butyl

4-((3-amino-6-chloro-2-hydroxyphenyl)sulfonyl)piperidine-1-carboxylate (32 g, $82 \mathrm{mmol}, 57.6 \%$ yield) as a brown oil.

MS-ESI (m/z): $[\mathrm{M}+\mathrm{Na}]^{+} 412.9$.

\section{Step 5: 1,1-dimethylethyl}

\section{4-\{[6-chloro-3-(\{[(2,3-dichlorophenyl)amino]carbonyl\}amino)-2-hydroxyphenyl]sulfonyl\}-1-piperidinecarboxylate}

A mixture of 1,1-dimethylethyl 4-[(3-amino-6-chloro-2-hydroxyphenyl)sulfonyl]-1-piperidinecarboxylate (26.9 g, 68.8 $\mathrm{mmol})$ and 1,2-dichloro-3-isocyanatobenzene (14.23 g, $76 \mathrm{mmol})$ in DCM (250 mL) was stirred at room temperature overnight. The mixture was concentrated to afford 1,1-dimethylethyl

4-\{[6-chloro-3-(\{[(2,3-dichlorophenyl)amino]carbonyl $\}$ amino)-2-hydroxyphenyl]sulfonyl $\}$-1-piperidinecarboxylate (40 g, 62.2 mmol, $90 \%$ yield) as a white solid. MS-ESI (m/z): $[\mathrm{M}+\mathrm{Na}]^{+} 599.8$.

\section{Step 6: N-[4-chloro-2-hydroxy-3-(4-piperidinylsulfonyl)phenyl]-N'-(2,3-dichlorophenyl)urea}

To a solution of 1,1-dimethylethyl 4-\{[6-chloro-3-(\{[(2,3-dichlorophenyl)amino]carbonyl $\}$ amino)-2-hydroxyphenyl]sulfonyl $\}$-1-piperidinecarboxylate (40 g, 69.1 $\mathrm{mmol})$ in DCM $(250 \mathrm{~mL})$ was added $\mathrm{CF}_{3} \mathrm{COOH}(42.6 \mathrm{~mL}, 553 \mathrm{mmol})$. The reaction mixture was stirred at room temperature overnight. The mixture was concentrated in vacuo to afford N-[4-chloro-2-hydroxy-3-(4-piperidinylsulfonyl)phenyl]-N'-(2,3-dichlorophenyl)urea (40 g, $67.5 \mathrm{mmol}, 98 \%$ yield) as a white solid. $\delta \mathrm{H}\left(\mathrm{CDCl}_{3}, 400 \mathrm{MHz}\right): 1.95(4 \mathrm{H}, \mathrm{m}), 2.94(2 \mathrm{H}, \mathrm{m}), 3.31(2 \mathrm{H}, \mathrm{m}), 4.00(1 \mathrm{H}, \mathrm{m}), 7.20(1 \mathrm{H}, \mathrm{d}), 7.31(2 \mathrm{H}, \mathrm{m}), 8.00(1 \mathrm{H}, \mathrm{m})$, $8.32(1 \mathrm{H}, \mathrm{d}), 8.78(1 \mathrm{H}, \mathrm{m}), 9.15(1 \mathrm{H}, \mathrm{m}), 9.28(1 \mathrm{H}, \mathrm{s}), 9.39(1 \mathrm{H}, \mathrm{s}), 10.57(1 \mathrm{H}, \mathrm{s}) . \mathrm{MS}-\mathrm{ESI}(\mathrm{m} / \mathrm{z}): \mathrm{MH}^{+} 477.9$.

\section{N-\{4-chloro-2-hydroxy-3-[(1-methyl-4-piperidinyl)sulfonyl]phenyl\}-N'-(2,3-dichlorophenyl)urea (21)}
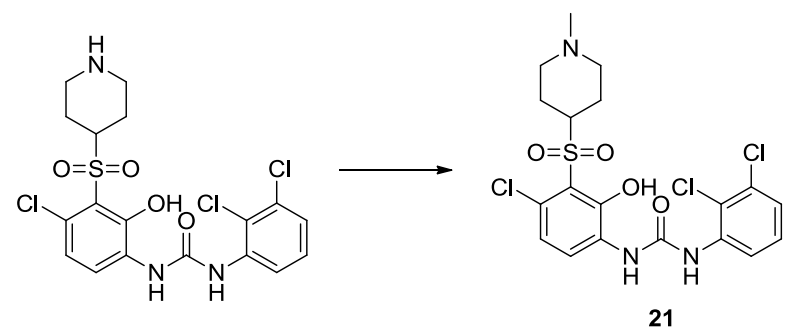

To a solution of N-[4-chloro-2-hydroxy-3-(4-piperidinylsulfonyl)phenyl]-N'-(2,3-dichlorophenyl)urea (40 g, $84 \mathrm{mmol})$ in DMF $(100 \mathrm{~mL})$ was added $35 \%$ formaldehyde solution $(68.3 \mathrm{~mL}, 835 \mathrm{mmol})$ and $\mathrm{AcOH}(5.25 \mathrm{~g}, 84 \mathrm{mmol})$ at $0{ }^{\circ} \mathrm{C}$. After stirring for $10 \mathrm{~min}, \mathrm{NaBH}_{3} \mathrm{CN}(20.07 \mathrm{~g}, 334 \mathrm{mmol})$ was added to the above solution portionwise. The reaction mixture was stirred for another $10 \mathrm{~min}$. Then, the mixture partitioned between ethyl acetate $(200 \mathrm{~mL})$ and saturated $\mathrm{NH}_{4} \mathrm{Cl}$ solution. The organic layer was washed with saturated brine $(100 \mathrm{~mL})$, dried over sodium sulfate and concentrated in vacuo. The resulting residue was purified by N-\{4-chloro-2-hydroxy-3-[(1-methyl-4-piperidinyl)sulfonyl]phenyl\}-N'-(2,3-dichlorophenyl)urea (15 g, $24.72 \mathrm{mmol}, 29.6 \%$ yield) as a white solid. ${ }^{1} \mathrm{H}$ NMR (400 MHz, DMSO-d $\left.d_{6}\right) 1.89$ - 2.06 (2 H, m), 2.08 - 2.18 (2 H, m), 2.76 (3 H, s), 3.07 (2 H, t, $J=11.8 \mathrm{~Hz}), 3.46$ - 3.58 (2 H, m), 3.90 - 4.04 (1 H, m), 7.21 (1 H, d, J=8.8 Hz), 7.27 - 7.34 (2 H, m), 7.97 - 8.10 (1 H, m), 8.35 (1 H, d, J=8.8 Hz), 9.30 (1 H, s), 9.39 (1 H, s), 10.30 (1 H, br. s.); ${ }^{13} \mathrm{C}$ NMR (101 MHz, DMSO- $\left.d_{6}\right)$ 152.7, 149.6, 138.1, 132.2, 
1-(4-chloro-2-hydroxy-3-(1-methylpiperidin-4-ylsulfonyl)phenyl)-3-(2-chloro-3-fluorophenyl)urea (22)
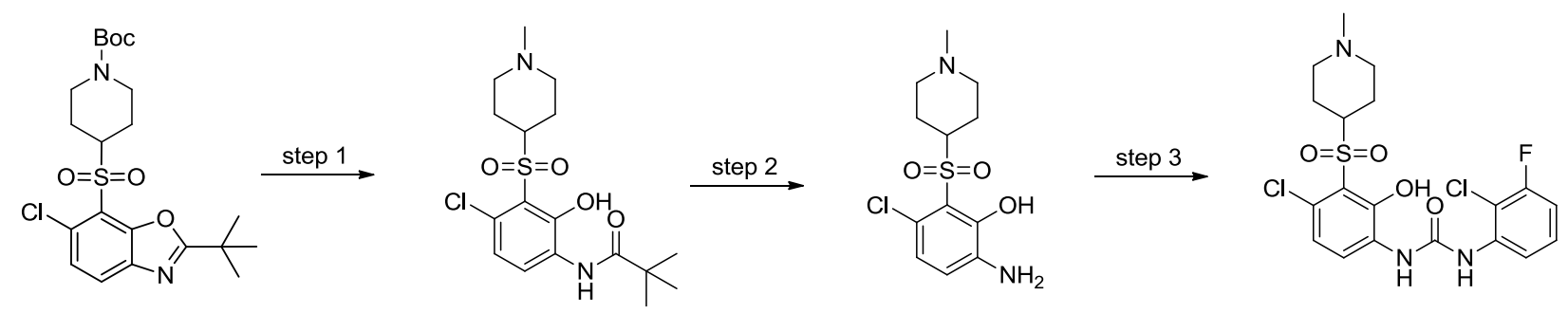

22

Step 1: N-[4-chloro-2-hydroxy-3-(1-methyl-piperidine-4-sulfonyl)-phenyl]-2,2-dimethyl-propionamide

A mixture of 4-(2-tert-butyl-6-chloro-benzooxazole-7-sulfonyl)-piperidine-1-carboxylic acid tert-butyl ester (4 g) in $\mathrm{HCOOH} / \mathrm{HCHO}(10 \mathrm{~mL}, 2: 3)$ was stirred at $100{ }^{\circ} \mathrm{C}$ for $3 \mathrm{~h}$. Then the reaction was cooled to room temperature and was basified $\mathrm{pH}$ to 7-8 and extracted with EtOAc $(3 \times 400 \mathrm{~mL})$. The organic layer was dried and concentrated. The residue was purified by silica gel column chromatography eluting with $0-2 \% \mathrm{MeOH}$ in DCM to afford N-[4-chloro-2-hydroxy-3-(1-methyl-piperidine-4-sulfonyl)-phenyl]-2,2-dimethyl-propionamide (2.1 g). MS (ES): $\mathrm{C}_{17} \mathrm{H}_{25} \mathrm{ClN}_{2} \mathrm{O}_{4} \mathrm{~S}$ requires 388; found $389\left(\mathrm{M}+\mathrm{H}^{+}\right)$.

\section{Step 2: 6-amino-3-chloro-2-(1-methyl-piperidine-4-sulfonyl)-phenol}

A solution of N-[4-chloro-2-hydroxy-3-(1-methyl-piperidine-4-sulfonyl)-phenyl]-2,2- dimethyl-propionamide (2.1 g, 5.4 $\mathrm{mmol})$ in dioxane $(21 \mathrm{~mL})$ and $\mathrm{H}_{2} \mathrm{SO}_{4}(42 \mathrm{~mL}, 30 \%)$ was stirred at reflux overnight. Then the mixture was cooled to room temperature and was basified $\mathrm{pH}$ to 7 . The resulting mixture was extracted with EtOAc $(3 \mathrm{x} 400 \mathrm{~mL})$. The combined organic layer was dried over sodium sulfate and concentrated to afford 6-amino-3-chloro-2-(1-methyl-piperidine-4-sulfonyl)-phenol $(1.9 \mathrm{~g})$, which was used for next step without further purification. MS (ES): $\mathrm{C}_{12} \mathrm{H}_{17} \mathrm{ClN}_{2} \mathrm{O}_{3} \mathrm{~S}$ requires 304; found $305\left(\mathrm{M}+\mathrm{H}^{+}\right)$.

\section{Step 3: 1-(4-chloro-2-hydroxy-3-(1-methylpiperidin-4-ylsulfonyl)phenyl)-3-(2-chloro-3-fluorophenyl)urea}

A solution of 6-amino-3-chloro-2-((1-methylpiperidin-4-yl)sulfonyl)phenol $\quad\left(\begin{array}{llllll}14.5 & \mathrm{~g}, & 47.6 & \mathrm{mmol}) & \mathrm{and}\end{array}\right.$ 2-chloro-1-fluoro-3-isocyanatobenzene $(6.12 \mathrm{~g}, 35.7 \mathrm{mmol})$ in $\mathrm{DCM}(10 \mathrm{~mL})$ was stirred at $25{ }^{\circ} \mathrm{C}$ for $18 \mathrm{~h}$. The mixture was adjusted $\mathrm{pH}$ to $7 \sim 8$, partitioned between ethyl $(400 \mathrm{~mL})$ and water $(200 \mathrm{~mL})$. The organic layer was dried over sodium sulfate, and concentrated in vacuo. The resulting residue was purified by silica gel column chromatography eluting $0-5 \% \mathrm{MeOH}$ in DCM to afford 1-(4-chloro-2-hydroxy-3-((1-methylpiperidin-4-yl)sulfonyl)phenyl)-3-(2-chloro-3-fluorophenyl)urea (11.0 g, $21.96 \mathrm{mmol}, 46.2 \%$ yield) as a white solid. $\delta \mathrm{H}\left(\mathrm{DMSO}-d_{6}, 400 \mathrm{MHz}\right): 1.93 \quad(2 \mathrm{H}, \mathrm{m}), 2.10 \quad(2 \mathrm{H}, \mathrm{d}), 2.73(3 \mathrm{H}, \mathrm{s}), 3.01 \quad(2 \mathrm{H}$, m), $3.51(2 \mathrm{H}, \mathrm{m}), 3.95(1 \mathrm{H}, \mathrm{m}), 7.06(1 \mathrm{H}, \mathrm{t}), 7.19(1 \mathrm{H}, \mathrm{d}), 7.30(1 \mathrm{H}, \mathrm{dd}), 7.90(1 \mathrm{H}, \mathrm{d}), 8.33(1 \mathrm{H}, \mathrm{d}), 9.25(1 \mathrm{H}, \mathrm{s}), 9.34(1 \mathrm{H}, \mathrm{s})$. ${ }^{13} \mathrm{C}$ NMR (101 MHz, DMSO-d $\left.d_{6}\right) 159.3,156.9,152.7,149.8,138.1,129.8,128.6,128.5,125.4,124.5,123.1,118.0,116.7,57.5$, 51.8, 42.9, 22.1. MS (ES): $\mathrm{C}_{19} \mathrm{H}_{20} \mathrm{Cl}_{2} \mathrm{FN}_{3} \mathrm{O}_{4} \mathrm{~S}$ requires 475; found $476\left(\mathrm{M}+\mathrm{H}^{+}\right)$.

1-(4-chloro-3-((1-ethylpiperidin-4-yl)sulfonyl)-2-hydroxyphenyl)-3-(2-chloro-3-fluorophenyl)urea (23)
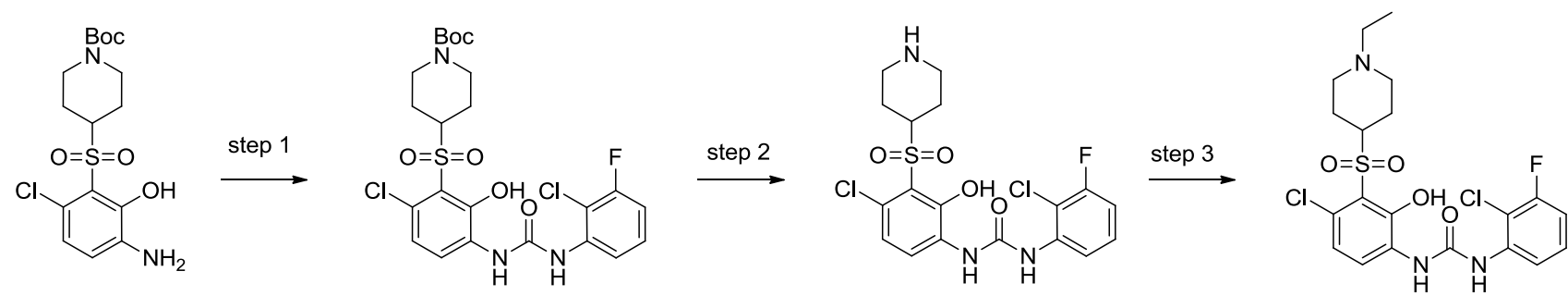

Step 1: tert-butyl 4-((6-chloro-3-(3-(2-chloro-3-fluorophenyl)ureido)-2-hydroxyphenyl)sulfonyl)piperidine-1-carboxylate 
A mixture of tert-butyl 4-((3-amino-6-chloro-2-hydroxyphenyl)sulfonyl)piperidine-1-carboxylate (0.5 g, $1.279 \mathrm{mmol})$ and 2-chloro-1-fluoro-3-isocyanatobenzene $(0.219 \mathrm{~g}, 1.279 \mathrm{mmol})$ in DCM $(15 \mathrm{~mL})$ was stirred at room temperature overnight. The mixture was concentrated and purified by silica gel column chromatography eluting with 10-30\% ethyl acetate in petroleum ether to afford tert-butyl

4-((6-chloro-3-(3-(2-chloro-3-fluorophenyl)ureido)-2-hydroxyphenyl)sulfonyl)piperidine-1-carboxylate (0.5 g , $0.89 \mathrm{mmol}$, $69.5 \%$ yield). MS-ESI (m/z): $[\mathrm{M}+\mathrm{Na}]^{+} 583.9$.

\section{Step 2: 1-(4-chloro-2-hydroxy-3-(piperidin-4-ylsulfonyl)phenyl)-3-(2-chloro-3-fluorophenyl)urea}

To a solution of tert-butyl

4-((6-chloro-3-(3-(2-chloro-3-fluorophenyl)ureido)-2-hydroxyphenyl)sulfonyl)piperidine-1-carboxylate (0.5 g, $0.89 \mathrm{mmol})$ in DCM $(15 \mathrm{~mL})$ was added $\mathrm{CF}_{3} \mathrm{COOH}(0.685 \mathrm{~mL}, 8.89 \mathrm{mmol})$. The reaction mixture was stirred at room temperature overnight. Then, the mixture was concentrated to afford

1-(4-chloro-2-hydroxy-3-(piperidin-4-ylsulfonyl)phenyl)-3-(2-chloro-3-fluorophenyl)urea (0.5 g) as a white solid. MS-ESI $(\mathrm{m} / \mathrm{z}): \mathrm{MH}^{+} 462.1$.

\section{Step 3: 1-(4-chloro-3-((1-ethylpiperidin-4-yl)sulfonyl)-2-hydroxyphenyl)-3-(2-chloro-3-fluorophenyl)urea}

To a solution of 1-(4-chloro-2-hydroxy-3-(piperidin-4-ylsulfonyl)phenyl)-3-(2-chloro-3-fluorophenyl)urea (500 mg, 1.081 $\mathrm{mmol})$ in DMF (5 mL), was added acetaldehyde (0.607 mL, $10.81 \mathrm{mmol})$, AcOH (272 mg, $4.33 \mathrm{mmol})$ and $\mathrm{NaBH} 3 \mathrm{CN}(64.9$ $\mathrm{mg}, 1.081 \mathrm{mmol})$ at $0{ }^{\circ} \mathrm{C}$, and the mixture was stirred for $10 \mathrm{~min}$. The reaction was quenched with aq.NaHCO3, and then the mixture was extracted with EA $(2 \times 30 \mathrm{~mL})$. The organic layer was dried over $\mathrm{Na}_{2} \mathrm{SO}_{4}$ and concentrated in vacuo. The residue

was burified Mass Directed Autopreparation to afford

1-(4-chloro-3-((1-ethylpiperidin-4-yl)sulfonyl)-2-hydroxyphenyl)-3-(2-chloro-3-fluorophenyl)urea (120 mg) as a white solid. $\delta \mathrm{H}$ (DMSO- $\left.d_{6}, 400 \mathrm{MHz}\right): 1.20(3 \mathrm{H}, \mathrm{m}), 2.02(2 \mathrm{H}, \mathrm{m}), 2.13(2 \mathrm{H}, \mathrm{m}), 3.08(3 \mathrm{H}, \mathrm{m}), 3.53(1 \mathrm{H}, \mathrm{m}), 3.61(2 \mathrm{H}, \mathrm{m}), 4.03(1 \mathrm{H}$, m), $7.09(1 \mathrm{H}, \mathrm{m}), 7.25(1 \mathrm{H}, \mathrm{d}), 7.34(1 \mathrm{H}, \mathrm{td}), 7.95(1 \mathrm{H}, \mathrm{d}), 8.38(1 \mathrm{H}, \mathrm{d}), 9.29(1 \mathrm{H}, \mathrm{s}), 9.39(1 \mathrm{H}, \mathrm{s}) .{ }^{13} \mathrm{C} \mathrm{NMR}(151 \mathrm{MHz}$, DMSO- $\left.d_{6}\right) 158.9,157.3,152.7,149.5,138.1,129.8,128.6,128.5,125.6,124.6,123.4,118.0,116.8,57.9,51.5,49.6,22.1,9.5$. $\delta \mathrm{F}$ (DMSO- $\left.d_{6}, 376 \mathrm{MHz}\right):-73.6,-113.9$. MS (ES): $\mathrm{C}_{20} \mathrm{H}_{22} \mathrm{Cl}_{2} \mathrm{FN}_{3} \mathrm{O}_{4} \mathrm{~S}$ requires 489; found $490\left(\mathrm{M}+\mathrm{H}^{+}\right)$.

\section{(S)-1-(4-chloro-2-hydroxy-3-((1-methylpyrrolidin-3-yl)sulfonyl)phenyl)-3-(2,3-dichlorophenyl)urea (24)}
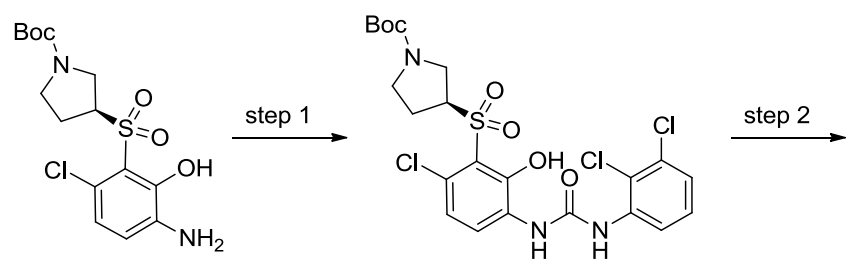
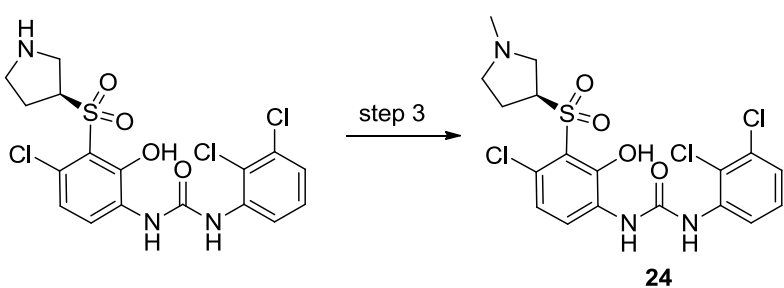

\section{Step 1: 1,1-dimethylethyl}

(3S)-3-\{[6-chloro-3-(\{[(2,3-dichlorophenyl)amino]carbonyl\}amino)-2-hydroxyphenyl]sulfonyl\}-1-pyrrolidinecarboxylate

To a solution of 1,1-dimethylethyl (3S)-3-[(3-amino-6-chloro-2-hydroxyphenyl)sulfonyl]-1-pyrrolidinecarboxylate (500 mg, $1.327 \mathrm{mmol}$ ) in N,N-Dimethylformamide (DMF) (10 mL) was added 1,2-dichloro-3-isocyanatobenzene (249 mg, $1.327 \mathrm{mmol})$. The resulted mixture was stirred at $20{ }^{\circ} \mathrm{C}$ overnight. The residue was concentrated and purified by column chromatography to afford 1,1-dimethylethyl

(3S)-3-\{[6-chloro-3-(\{[(2,3-dichlorophenyl)amino]carbonyl $\}$ amino)-2-hydroxyphenyl]sulfonyl $\}$-1-pyrrolidinecarboxylate (D28) (750 mg), which was used for next step without further purification. MS (ES): $\mathrm{C}_{22} \mathrm{H}_{24} \mathrm{Cl}_{3} \mathrm{~N}_{3} \mathrm{O}_{6} \mathrm{~S}$ requires 563; found 586 $\left(\mathrm{M}+\mathrm{Na}^{+}\right)$.

\section{Step 2: N-\{4-chloro-2-hydroxy-3-[(3S)-3-pyrrolidinylsulfonyl]phenyl\}-N'-(2,3-dichlorophenyl)urea}

To a solution of 1,1-dimethylethyl 
$\mathrm{mg}, 1.416 \mathrm{mmol})$ in Dichloromethane (DCM) $(15 \mathrm{~mL})$ was added TFA $(1.049 \mathrm{~mL}, 14.16 \mathrm{mmol})$. The resulted mix ture was stirred at $20{ }^{\circ} \mathrm{C}$ overnight and concentrated to afford

$\mathrm{N}$-\{4-chloro-2-hydroxy-3-[(3S)-3-pyrrolidinylsulfonyl]phenyl $\}-\mathrm{N}^{\prime}-(2,3$-dichlorophenyl)urea (D29) (750 mg), which was used for next step without further purification.MS (ES): $\mathrm{C}_{17} \mathrm{H}_{16} \mathrm{Cl}_{3} \mathrm{~N}_{3} \mathrm{O}_{4} \mathrm{~S}$ requires 463 ; found $464\left(\mathrm{M}+\mathrm{H}^{+}\right)$.

\section{Step 3: (S)-1-(4-chloro-2-hydroxy-3-((1-methylpyrrolidin-3-yl)sulfonyl)phenyl)-3-(2,3-dichlorophenyl)urea}

To a solution of $\mathrm{N}$-\{4-chloro-2-hydroxy-3-[(3S)-3-pyrrolidinylsulfonyl]phenyl\}-N'-(2,3-dichlorophenyl)urea (50 mg, $0.108 \mathrm{mmol})$ in DMF (2 mL) was added formaldehyde solution $(0.088 \mathrm{~mL}, 1.076 \mathrm{mmol})$ and AcOH $(6.46 \mathrm{mg}, 0.108 \mathrm{mmol})$. After stirring at room temperature for $10 \mathrm{~min}$. The mixture was added $\mathrm{NaBH}_{3} \mathrm{CN}(27.0 \mathrm{mg}, 0.430 \mathrm{mmol})$ and was stirred for additional $5 \mathrm{~min}$. Then the mixture was partitioned between ethyl acetate $(15 \mathrm{~mL})$ and saturated $\mathrm{NaHCO}_{3}$ solution $(10 \mathrm{~mL})$. The organic layer was washed with saturated brine, and dried over sodium sulfate and concentrated in vacuo. The resulting residue was purified by Auss to afrected N-(4-chloro-2-hydroxy-3-\{[(3S)-1-methyl-3-pyrrolidinyl]sulfonyl $\}$ phenyl)-N'-(2,3-dichlorophenyl)urea (8.5 mg, $0.014 \mathrm{mmol}$, $13.33 \%$ yield) as a white solid. $\delta \mathrm{H}\left(\mathrm{DMSO}-d_{6}, 400 \mathrm{MHz}\right): 2.37(2 \mathrm{H}, \mathrm{m}), 2.88(3 \mathrm{H}, \mathrm{s}), 3.71(4 \mathrm{H}, \mathrm{m}), 4.78$ (1 H, quin), $7.18(1$ $\mathrm{H}, \mathrm{m}), 7.33(2 \mathrm{H}, \mathrm{m}), 8.04(1 \mathrm{H}, \mathrm{m}), 8.26(1 \mathrm{H}, \mathrm{m}), 9.25(1 \mathrm{H}, \mathrm{s}), 9.38(1 \mathrm{H}, \mathrm{s}) . \delta \mathrm{F}$ (DMSO- $\left.d_{6}, 376 \mathrm{MHz}\right):-73.8 .{ }^{13} \mathrm{C} \mathrm{NMR}(101$ MHz, DMSO- $d_{6}$ ) 152.8, 150.0, 138.1, 132.2, 130.3, 128.5, 125.8, 124.7, 124.6, 123.0, 121.8, 121.3, 119.1, 61.2, 55.3, 53.9, 41.1, 25.1. MS (ES): $\mathrm{C}_{18} \mathrm{H}_{18} \mathrm{Cl}_{3} \mathrm{~N}_{3} \mathrm{O}_{4} \mathrm{~S}$ requires 477; found $478\left(\mathrm{M}+\mathrm{H}^{+}\right)$.

\section{N-(2-chloro-3-fluorophenyl)-N'-(4-chloro-2-hydroxy-3-\{[(3S)-1-methyl-3-pyrrolidinyl]sulfonyl\}phenyl)urea (25)}
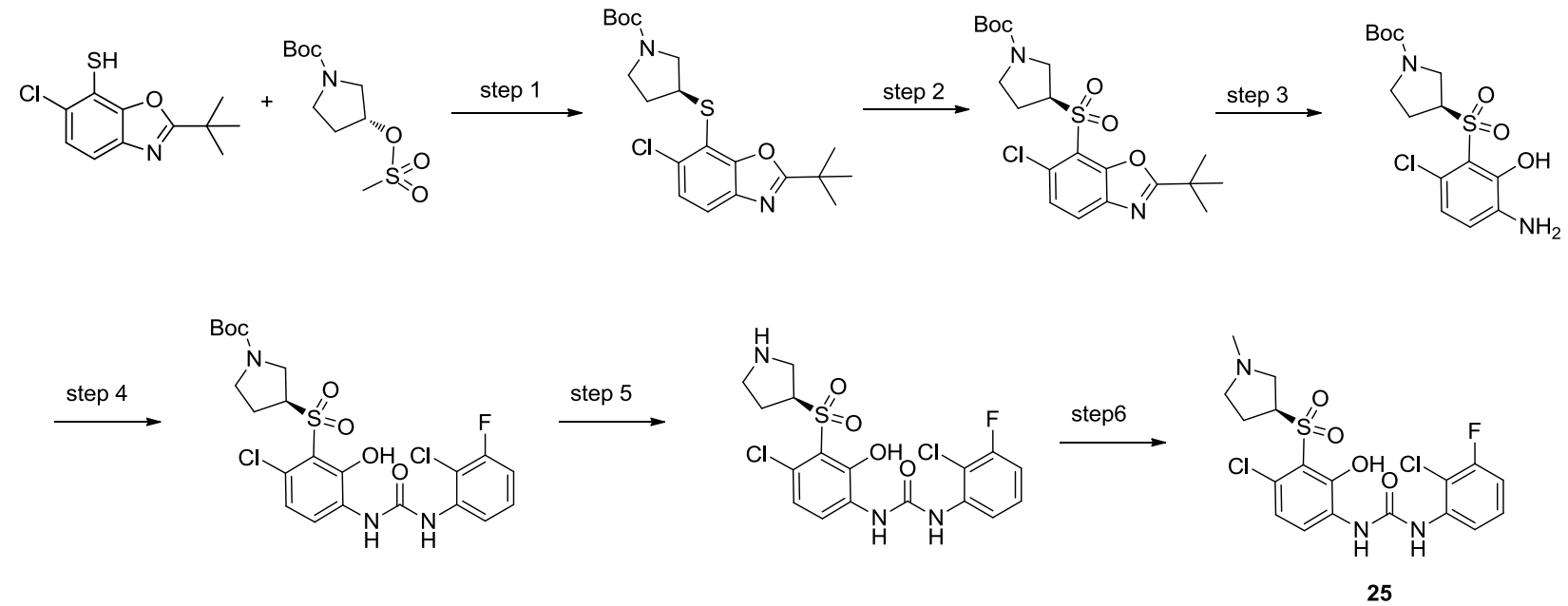

Step1: 1,1-dimethylethyl (3S)-3-\{[6-chloro-2-(1,1-dimethylethyl)-1,3-benzoxazol-7-yl]thio\}-1-pyrrolidinecarboxylate

To a solution of 6-chloro-2-(1,1-dimethylethyl)-1,3-benzoxazole-7-thiol (2369 mg, $9.80 \mathrm{mmol})$ and 1,1-dimethylethyl (3S)-3-[(methylsulfonyl)oxy]-1-pyrrolidinecarboxylate (2600 mg, $9.80 \mathrm{mmol})$ in DMF (30 mL) was added $\mathrm{Cs}_{2} \mathrm{CO}_{3}(6406 \mathrm{mg}$, $19.60 \mathrm{mmol})$. The reaction mixture was stirred at $50{ }^{\circ} \mathrm{C}$ overnight. After cooling, the reaction mixture was diluted with water $(50 \mathrm{~mL})$, extracted with EA $(2 \times 50 \mathrm{~mL})$, washed and driedover sodium sulphate. The organic layers were concentrated to afford 1,1-dimethylethyl (3S)-3-\{[6-chloro-2-(1,1-dimethylethyl)-1,3-benzoxazol-7-yl]thio\}-1-pyrrolidinecarboxylate (1500 mg), whichwas used for next step without further purification.MS (ES): $\mathrm{C}_{20} \mathrm{H}_{27} \mathrm{ClN}_{2} \mathrm{O}_{3} \mathrm{~S}$ requires 410; found $411\left(\mathrm{M}+\mathrm{H}^{+}\right)$.

Step2: 1,1-dimethylethyl (3S)-3-\{[6-chloro-2-(1,1-dimethylethyl)-1,3-benzoxazol-7-yl]sulfonyl\}-1-pyrrolidinecarboxylate

To a solution of 1,1-dimethylethyl

(3S)-3-\{[6-chloro-2-(1,1-dimethylethyl)-1,3-benzoxazol-7-yl]thio $\}-1$-pyrrolidinecarboxylate (3600 $\mathrm{mg}, 8.76 \mathrm{mmol})$ in Dichloromethane (DCM) $(30 \mathrm{~mL})$ was added 3-chlorobenzenecarboperoxoic acid $(3926 \mathrm{mg}, 17.52 \mathrm{mmol})$ at $0{ }^{\circ} \mathrm{C}$ under nitrogen. The resulted mixture was stirred at $20{ }^{\circ} \mathrm{C}$ overnight. The reaction was quenched with aq. NaHCO3, extracted with $\operatorname{DCM}(2 \times 50 \mathrm{~mL})$, washed with aq. $\mathrm{NaS}_{2} \mathrm{O}_{3}$, water and brine, and concentrated to afford 1,1-dimethylethyl (3S)-3-\{[6-chloro-2-(1,1-dimethylethyl)-1,3-benzoxazol-7-yl]sulfonyl \}-1-pyrrolidinecarboxylate (3600 mg), which was used 
for next step without further purification.MS (ES): $\mathrm{C}_{20} \mathrm{H}_{27} \mathrm{ClN}_{2} \mathrm{O}_{5} \mathrm{~S}$ requires 442 ; found $443\left(\mathrm{M}+\mathrm{H}^{+}\right)$.

\section{Step 3: 1,1-dimethylethyl (3S)-3-[(3-amino-6-chloro-2-hydroxyphenyl)sulfonyl]-1-pyrrolidinecarboxylate}

To a solution of 1,1-dimethylethyl

(3S)-3-\{[6-chloro-2-(1,1-dimethylethyl)-1,3-benzoxazol-7-yl] sulfonyl \}-1-pyrrolidinecarboxylate (1800 mg, $4.06 \mathrm{mmol})$ in dioxane $(20 \mathrm{~mL})$ and Water $(4.00 \mathrm{~mL})$ was added sulfuric acid $(2.166 \mathrm{~mL}, 40.6 \mathrm{mmol})$. The resulted solution was heated at $100{ }^{\circ} \mathrm{C}$ overnight. After cooling, the reaction was basified to $\mathrm{pH}=8$ with aq. $\mathrm{NaOH}$. To the above mixture was added $\mathrm{Boc}_{2} \mathrm{O}(0.74 \mathrm{~g}, 3.39 \mathrm{mmol})$ at $0{ }^{\circ} \mathrm{C}$, and stirred at $0{ }^{\circ} \mathrm{C}$ for 1 hour. The residue was seperated, and the aqueous layer was extracted with EA $(2 \times 50 \mathrm{~mL})$. The combined organic layers were dried over sodium sulphate and concentrated to afford 1,1-dimethylethyl (3S)-3-[(3-amino-6-chloro-2-hydroxyphenyl)sulfonyl]-1-pyrrolidinecarboxylate (1.0 g), which was used for next step without further purification.MS (ES): $\mathrm{C}_{15} \mathrm{H}_{21} \mathrm{ClN}_{2} \mathrm{O}_{5} \mathrm{~S}$ requires 376 ; found $377\left(\mathrm{M}+\mathrm{H}^{+}\right)$.

\section{Step 4: 1,1-dimethylethyl}

(3S)-3-\{[6-chloro-3-(\{[(2-chloro-3-fluorophenyl)amino]carbonyl\}amino)-2-hydroxyphenyl]sulfonyl\}-1-pyrrolidinecarbox ylate

A mixture of 1,1-dimethylethyl (3S)-3-[(3-amino-6-chloro-2-hydroxyphenyl)sulfonyl]-1-pyrrolidinecarboxylate (500 mg, $1.327 \mathrm{mmol}$ ) and 2-chloro-1-fluoro-3-isocyanatobenzene (341 mg, $1.990 \mathrm{mmol})$ in DMF (5 mL) was stirred at room temperature overnight and then concentrated in vacuo. The residue was purified by column chromatography to afford 1,1-dimethylethyl

(3S)-3-\{[6-chloro-3-(\{[(3-chloro-2-fluorophenyl)amino]carbonyl $\}$ amino)-2-hydroxyphenyl] sulfonyl $\}$-1-pyrrolidinecarboxylate as a white solid. (550 mg).MS (ES): $\mathrm{C}_{22} \mathrm{H}_{24} \mathrm{Cl}_{2} \mathrm{FN}_{3} \mathrm{O}_{6} \mathrm{~S}$ requires 547; found $447.9\left(\mathrm{M}+\mathrm{H}^{+}-100\right)$.

\section{Step 5: N-(2-chloro-3-fluorophenyl)-N'-\{4-chloro-2-hydroxy-3-[(3S)-3-pyrrolidinylsulfonyl]phenyl\}urea}

A mixture of 1,1-dimethylethyl

(3S)-3-\{[6-chloro-3-(\{[(2-chloro-3-fluorophenyl)amino]carbonyl $\}$ amino)-2-hydroxyphenyl]sulfonyl $\}$-1-pyrrolidinecarboxylate $(500 \mathrm{mg}, 0.912 \mathrm{mmol})$ and $\mathrm{CF}_{3} \mathrm{COOH}(0.675 \mathrm{~mL}, 9.12 \mathrm{mmol})$ in DCM $(15 \mathrm{~mL})$ was stirred at room temperature overnight. The resulted mixture was concentrated to afford

N-(2-chloro-3-fluorophenyl)-N'-\{4-chloro-2-hydroxy-3-[(3S)-3-pyrrolidinylsulfonyl]phenyl $\}$ urea (550 mg), which was used for next step without further purification. MS (ES): $\mathrm{C}_{17} \mathrm{H}_{16} \mathrm{Cl}_{2} \mathrm{FN}_{3} \mathrm{O}_{4} \mathrm{~S}$ requires 447; found $448\left(\mathrm{M}+\mathrm{H}^{+}\right)$.

\section{Step 6: N-(2-chloro-3-fluorophenyl)-N'-(4-chloro-2-hydroxy-3-\{[(3S)-1-methyl-3-pyrrolidinyl]sulfonyl $\}$ phenyl)urea,} Trifluoroacetic acid salt

To a solution of N-(2-chloro-3-fluorophenyl)-N'-\{4-chloro-2-hydroxy-3-[(3S)-3-pyrrolidinylsulfonyl]phenyl $\}$ urea (250 mg, $0.558 \mathrm{mmol})$ in DMF (3 mL) was added $35 \%$ formaldehyde solution $(0.456 \mathrm{~mL}, 5.58 \mathrm{mmol})$, AcOH $(33.5 \mathrm{mg}, 0.558 \mathrm{mmol})$ and $\mathrm{NaBH}_{3} \mathrm{CN}(140 \mathrm{mg}, 2.231 \mathrm{mmol})$ at $0{ }^{\circ} \mathrm{C}$. The mixture was stirred for $5 \mathrm{~min}$. The reaction was quenched with aq. $\mathrm{NaHCO}_{3}$, and then the mixture was extracted with EA $(2 \times 20 \mathrm{~mL})$. The organic layer was dried over $\mathrm{Na}_{2} \mathrm{SO}_{4}$ and concentrated. The resulting residue was purified by Mass Directed Autopreparation to afford

N-(2-chloro-3-fluorophenyl)-N'-(4-chloro-2-hydroxy-3-\{[(3S)-1-methyl-3-pyrrolidinyl]sulfonyl $\}$ phenyl)urea (48 mg) as a TFA salt. $\delta \mathrm{H}$ (DMSO- $\left.d_{6}, 400 \mathrm{MHz}\right): 2.40(2 \mathrm{H}, \mathrm{m}), 2.88(3 \mathrm{H}, \mathrm{s}), 3.73(4 \mathrm{H}, \mathrm{m}), 4.78(1 \mathrm{H}, \mathrm{m}), 7.09(1 \mathrm{H}, \mathrm{m}), 7.18(1 \mathrm{H}, \mathrm{d}), 7.34(1 \mathrm{H}$, td), $7.94(1 \mathrm{H}, \mathrm{d}), 8.27$ (1 H, d), $9.26(1 \mathrm{H}, \mathrm{s}), 9.39$ (1 H, s). $\delta \mathrm{F}$ (DMSO-d 6 , 376MHz): -73.6, -113.6. MS (ES):

$\mathrm{C}_{18} \mathrm{H}_{18} \mathrm{Cl}_{2} \mathrm{FN}_{3} \mathrm{O}_{4} \mathrm{~S}$ requires 461.0 ; found $461.9\left(\mathrm{M}+\mathrm{H}^{+}\right)$.

(S)-1-(4-chloro-2-hydroxy-3-((1-methylazepan-4-yl)sulfonyl)phenyl)-3-(2-chloro-3-fluorophenyl)urea (26) 

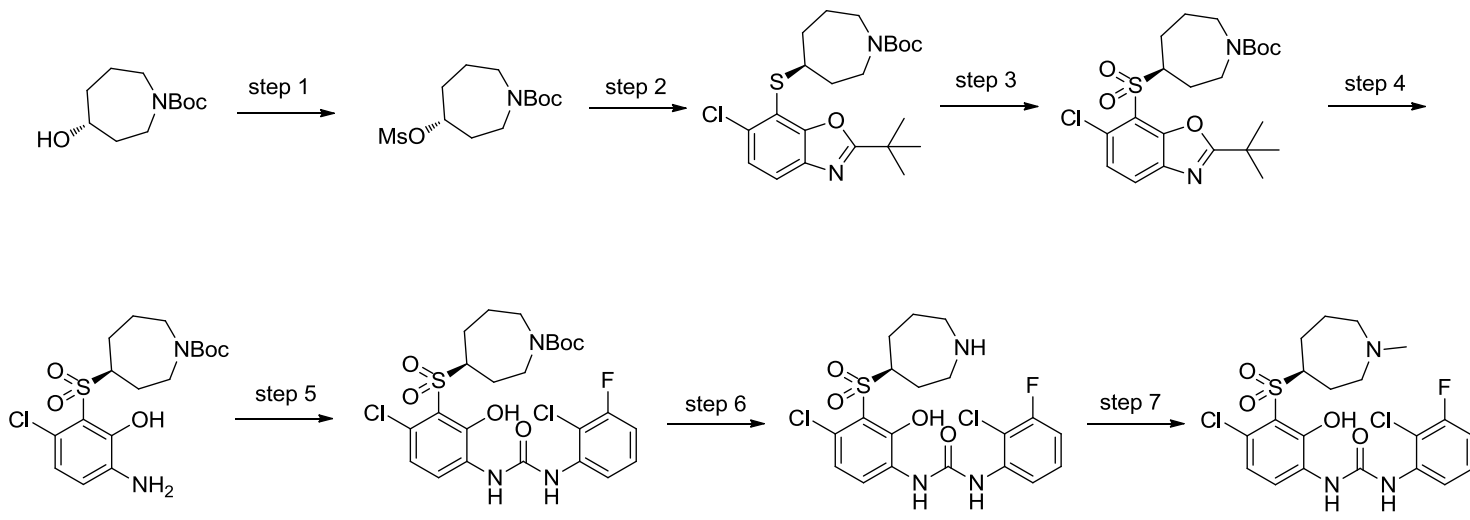

26

\section{Step 1: (R)-tert-butyl 4-((methylsulfonyl)oxy)azepane-1-carboxylate}

To a solution of (R)-tert-butyl 4-hydroxyazepane-1-carboxylate (1000 mg, $4.64 \mathrm{mmol})$ in DCM (20 mL) was added $\mathrm{Et}_{3} \mathrm{~N}$ $(1.295 \mathrm{~mL}, 9.29 \mathrm{mmol})$ and methanesulfonyl chloride $(692 \mathrm{mg}, 6.04 \mathrm{mmol})$. The resulting mixture was stirred at room temperature overnight. The reaction was queched with aq. NaHCO3, extracted with DCM, washed and dried over anhydrous sodium sulfate. The organic layer was concentrated to afford (R)-tert-butyl 4-((methylsulfonyl)oxy)azepane-1-carboxylate (1.5 g). MS (ES): $\mathrm{C}_{12} \mathrm{H}_{23} \mathrm{NO}_{5} \mathrm{~S}$ requires 293; found $294\left(\mathrm{M}+\mathrm{H}^{+}\right)$.

\section{Step 2: (S)-tert-butyl 4-((2-(tert-butyl)-6-chlorobenzo[d]oxazol-7-yl)thio)azepane-1-carboxylate}

To a solution of (R)-tert-butyl 4-((methylsulfonyl)oxy)azepane-1-carboxylate $\quad\left(\begin{array}{lllll}1.5 & \mathrm{~g}, & 5.11 & \mathrm{mmol}) & \mathrm{and}\end{array}\right.$ 2-(tert-butyl)-6-chlorobenzo[d]oxazole-7-thiol (1.483 g, $6.14 \mathrm{mmol})$ in DMF (50 mL) was added K2CO3 (1.413 g, 10.23 mmol). The reaction was stirred at $80^{\circ} \mathrm{C}$ overnight and poured into water $(50 \mathrm{~mL})$, extracted with EA $(50 \mathrm{~mL} * 3)$, washed and dried over anhydrous sodium sulfate. The organic layer was concentrated to afford (S)-tert-butyl 4-((2-(tert-butyl)-6-chlorobenzo[d]oxazol-7-yl)thio)azepane-1-carboxylate (1.2 g), which was used for the next step without purification. MS (ES): $\mathrm{C}_{22} \mathrm{H}_{31} \mathrm{ClN}_{2} \mathrm{O}_{3} \mathrm{~S}$ requires 438; found $439\left(\mathrm{M}+\mathrm{H}^{+}\right)$.

\section{Step 3: (S)-tert-butyl 4-((2-(tert-butyl)-6-chlorobenzo[d]oxazol-7-yl)sulfonyl)azepane-1-carboxylate}

A mixture of (S)-tert-butyl 4-((2-(tert-butyl)-6-chlorobenzo[d]oxazol-7-yl)thio) azepane-1-carboxylate (1200 mg, 2.73 mmol) and mCPBA (1225 mg, $5.47 \mathrm{mmol})$ in DCM (20 mL) was stirred at room temperature overnight. The reaction was quenched with aq. $\mathrm{NaHCO}_{3}(10 \mathrm{~mL})$ and aq. $\mathrm{Na}_{2} \mathrm{~S}_{2} \mathrm{O}_{3}(10 \mathrm{~mL})$, extracted with DCM $(2 \times 50 \mathrm{~mL})$, washed and dried over anhydrous sodium sulfate. The organic layer was concentrated and purified by column chromatography to afford (S)-tert-butyl 4-((2-(tert-butyl)-6-chlorobenzo[d]oxazol-7-yl)sulfonyl)azepane-1-carboxylate. MS (ES): $\mathrm{C}_{22} \mathrm{H}_{31} \mathrm{ClN}_{2} \mathrm{O}_{5} \mathrm{~S}$ requires 470; found $471\left(\mathrm{M}+\mathrm{H}^{+}\right)$.

\section{Step 4: (S)-tert-butyl 4-((3-amino-6-chloro-2-hydroxyphenyl)sulfonyl)azepane-1-carboxylate}

To a solution of (S)-tert-butyl 4-((2-(tert-butyl)-6-chlorobenzo[d]oxazol-7-yl)sulfonyl) azepane-1-carboxylate (600 mg, $1.27 \mathrm{mmol})$ in 1,4-Dioxane $(20 \mathrm{~mL}) /$ Water $(5.00 \mathrm{~mL})$ was added $\mathrm{H}_{2} \mathrm{SO}_{4}(0.543 \mathrm{~mL}, 10.19 \mathrm{mmol})$. The reaction mixture was stirred at $100{ }^{\circ} \mathrm{C}$ overnight and for another 1 day. Then the reaction was cooled and basified with $2 \mathrm{M} \mathrm{NaOH}$ to $\mathrm{pH}=8$. To the mixture was added $\mathrm{Boc}_{2} \mathrm{O}(0.296 \mathrm{~mL}, 1.274 \mathrm{mmol})$. The resulting mixture was stirred at room temperature for 2 hours and then poured into water $(50 \mathrm{~mL})$, extracted with EA $\left(50 \mathrm{~mL}^{*} 2\right)$, washed and dried over anhydrous sodium sulfate. The organic layer was concentrated to afford (S)-tert-butyl 4-((3-amino-6-chloro-2-hydroxyphenyl)sulfonyl)azepane-1-carboxylate (400 mg), which was used for next step without further purification. MS (ES): $\mathrm{C}_{17} \mathrm{H}_{25} \mathrm{ClN}_{2} \mathrm{O}_{5} \mathrm{~S}$ requires 404; found $405\left(\mathrm{M}+\mathrm{H}^{+}\right)$.

\section{Step 5: $\quad$ (S)-tert-butyl 4-((6-chloro-3-(3-(2-chloro-3-fluorophenyl)ureido)-2-hydroxy} phenyl)sulfonyl)azepane-1-carboxylate

To a solution of 2-chloro-3-fluoroaniline $(0.120 \mathrm{~mL}, 0.988 \mathrm{mmol})$ in DCM $(20 \mathrm{~mL})$, was added triethylamine $(0.413 \mathrm{~mL}$, $2.96 \mathrm{mmol})$ and then bis(trichloromethyl) carbonate $(98 \mathrm{mg}, 0.329 \mathrm{mmol})$. The raction was stirred at room temperature for 10 min. To the above mixture was added a solution of (S)-tert-butyl 
4-((3-amino-6-chloro-2-hydroxyphenyl)sulfonyl)azepane-1-carboxylate (400 mg, $0.988 \mathrm{mmol})$ in DCM (10 mL). The resulting mxiture was stirred at room temperature overnight. The residue was concentrated and purified by column chromatography to afford (S)-tert-butyl 4-((6-chloro-3-(3-(2-chloro-3-fluorophenyl) ureido)-2-hydroxyphenyl)sulfonyl)azepane-1-carboxylate $\left(250 \mathrm{mg}\right.$ ) as a white solid. $\mathrm{MS}(\mathrm{ES}): \mathrm{C}_{24} \mathrm{H}_{28} \mathrm{Cl}_{2} \mathrm{FN}_{3} \mathrm{O}_{6} \mathrm{~S}$ requires 575 ; found $576\left(\mathrm{M}+\mathrm{H}^{+}\right)$.

Step 6: (S)-1-(3-(azepan-4-ylsulfonyl)-4-chloro-2-hydroxyphenyl)-3-(2-chloro-3-fluoro phenyl)urea

To a solution of (S)-tert-butyl

4-((6-chloro-3-(3-(2-chloro-3-fluorophenyl)ureido)-2-hydroxyphenyl)sulfonyl)azepane-1-carboxylate (250 mg, $0.434 \mathrm{mmol})$ in DCM $(10 \mathrm{~mL})$ was added TFA $(0.334 \mathrm{~mL}, 4.34 \mathrm{mmol})$. The resulting mixture was stirred at room temperature overnight. The reaction mixture was concentrated to afford

(S)-1-(3-(azepan-4-ylsulfonyl)-4-chloro-2-hydroxyphenyl)-3-(2-chloro-3-fluorophenyl)urea (250 mg), which was used for next step without further purification. $\mathrm{MS}(\mathrm{ES}): \mathrm{C}_{19} \mathrm{H}_{20} \mathrm{Cl}_{2} \mathrm{FN}_{3} \mathrm{O}_{4} \mathrm{~S}$ requires 475 ; found $476\left(\mathrm{M}^{+} \mathrm{H}^{+}\right)$.

\section{Step 7: (S)-1-(4-chloro-2-hydroxy-3-((1-methylazepan-4-yl)sulfonyl)phenyl)-3-(2-chloro-3-fluorophenyl)urea}

To a solution of (S)-1-(3-(azepan-4-ylsulfonyl)-4-chloro-2-hydroxyphenyl)-3-(2-chloro-3-fluorophenyl)urea (250 mg, $0.525 \mathrm{mmol})$ in DMF $(10 \mathrm{~mL})$ was added acetic acid $(0.030 \mathrm{~mL}, 0.525 \mathrm{mmol})$ and formaldehyde $(0.413 \mathrm{~mL}, 5.25 \mathrm{mmol})$. The reaction mixture was cooled to $0{ }^{\circ} \mathrm{C}$ and stirred for $10 \mathrm{~min}$, then to the mixture was added $\mathrm{NaCNBH}_{3}(132 \mathrm{mg}, 2.099 \mathrm{mmol})$ portionwise. After stirring at $0{ }^{\circ} \mathrm{C}$ for $10 \mathrm{~min}$, the mixture was partitioned betwwen ethyl acetate $(30 \mathrm{~mL})$ and saturated $\mathrm{NaHCO}_{3}$ solution $(20 \mathrm{~mL})$. The organic layer was washed with saturated brine $(30 \mathrm{~mL})$, dried over sodium sulfate, and concentrated in vacuo. The resulting residue was purified by Mass Directed Autopreparation and freeze-dried to afford (S)-1-(4-chloro-2-hydroxy-3-((1-methylazepan-4-yl)sulfonyl)phenyl)-3-(2-chloro-3-fluorophenyl)urea, trifluoroacetic acid salt (60 mg, 0.099 mmol, $18.92 \%$ yield). ${ }^{1} \mathrm{H}$ NMR (400 MHz, DMSO-d $) 1.98$ - 2.16 (2 H, m), 2.77 (6 H, s), 3.12 - 3.26 (2 H, m), $3.72-3.83(2 \mathrm{H}, \mathrm{m}), 7.04-7.14(1 \mathrm{H}, \mathrm{m}), 7.20(1 \mathrm{H}, \mathrm{d}, J=8.8 \mathrm{~Hz}), 7.34(1 \mathrm{H}, \mathrm{td}, J=8.4,6.5 \mathrm{~Hz}), 7.95(1 \mathrm{H}, \mathrm{d}, J=8.5 \mathrm{~Hz}), 8.34$ $(1 \mathrm{H}, \mathrm{d}, J=8.8 \mathrm{~Hz}), 9.29(1 \mathrm{H}, \mathrm{s}), 9.37(1 \mathrm{H}, \mathrm{s}) . \delta \mathrm{F}$ (DMSO-d, $376 \mathrm{MHz}):-78.9,-118.1$. MS-ESI (m/z): $\mathrm{MH}^{+} 490.0$.

\section{1-(4-chloro-2-hydroxy-3-((2-methyl-2-azaspiro[3.3]heptan-6-yl)sulfonyl)phenyl)-3-(2-chloro-3-fluorophenyl)urea (27)}
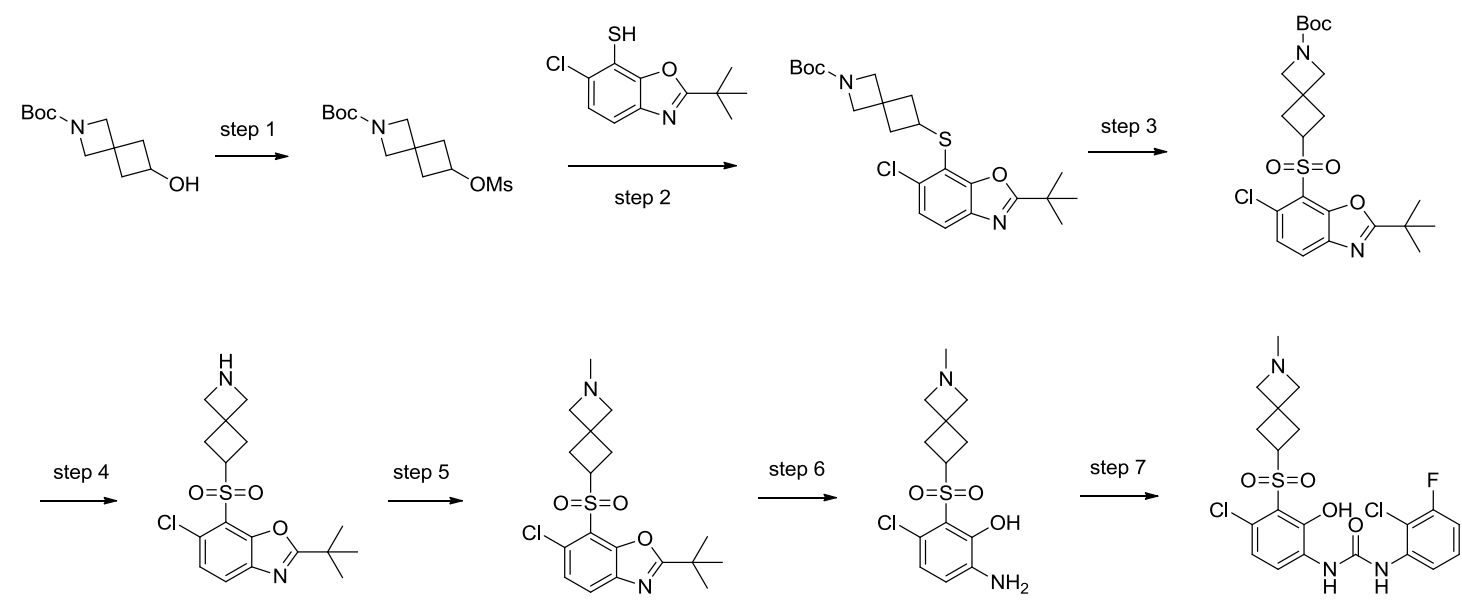

27

\section{Step 1: tert-butyl 6-((methylsulfonyl)oxy)-2-azaspiro[3.3]heptane-2-carboxylate}

To a solution of tert-butyl 6-hydroxy-2-azaspiro[3.3] heptane-2-carboxylate (1.3 g, $6.10 \mathrm{mmol}$ in DCM (20 mL) was added triethylamine $(1.7 \mathrm{~mL}, 12.19 \mathrm{mmol})$ and $\mathrm{MsCl}(0.57 \mathrm{~mL}, 7.31 \mathrm{mmol})$. The reaction mixture was stirred at $0{ }^{\circ} \mathrm{C}$ for $30 \mathrm{~min}$. Then, the mixture was partitioned between DCM $(50 \mathrm{~mL})$ and saturated $\mathrm{NaHCO}_{3}$ solution $(50 \mathrm{~mL})$. The organic layer was washed with saturated brine, dried over sodium sulfate and concentrated in vacuo to afford tert-butyl 6-((methylsulfonyl)oxy)-2-azaspiro[3.3]heptane-2-carboxylate (1.7 g, $5.83 \mathrm{mmol}, 96 \%$ yield) as a white solid. MS-ESI (m/z): [M+Na $]^{+} 314.0$ 


\section{Step 2: tert-butyl 6-((2-(tert-butyl)-6-chlorobenzo[d]oxazol-7-yl)thio)-2-azaspiro[3.3]heptane-2-carboxylate}

To a solution of tert-butyl 6-((methylsulfonyl)oxy)-2-azaspiro[3.3]heptane-2-carboxylate (1.7 g, $5.83 \mathrm{mmol})$ in DMF (50 $\mathrm{mL}$ ) was added 2-(tert-butyl)-6-chlorobenzo[d] oxazole-7-thiol $(1.151 \mathrm{~mL}, 7.00 \mathrm{mmol})$ and potassium carbonate $(1.61 \mathrm{~g}, 11.67$ mmol). The reaction mixture was stirred at $100{ }^{\circ} \mathrm{C}$ overnight. After cooling to room temperature, the reaction mixture was partitioned between ethyl acetate $(100 \mathrm{~mL})$ and water $(100 \mathrm{~mL})$. The organic layer was washed with saturated brine $(100 \mathrm{~mL})$, dried over sodium sulfate and concentrated in vacuo. The resuting residue was purified by silica gel column chromatography eluting with $10-30 \%$ ethyl acetate in perotroleum ether to afford tert-butyl 6-((2-(tert-butyl)-6-chlorobenzo[d]oxazol-7-yl)thio)-2-azaspiro[3.3]heptane-2-carboxylate (2.3 g, $5.26 \mathrm{mmol}, 90 \%$ yield) as a white solid. MS-ESI (m/z): $[\mathrm{M}+\mathrm{Na}]^{+} 459.0$.

\section{Step 3: tert-butyl 6-((2-(tert-butyl)-6-chlorobenzo[d]oxazol-7-yl)sulfonyl)-2-azaspiro[3.3]heptane-2-carboxylate}

To a solution of tert-butyl 6-((2-(tert-butyl)-6-chlorobenzo[d]oxazol-7-yl)thio)-2-azaspiro[3.3]heptane-2-carboxylate (2.2 g, $5.03 \mathrm{mmol})$ in DCM $(30 \mathrm{~mL})$ was added $\mathrm{m}-\mathrm{CPBA}(2.26 \mathrm{~g}, 10.07 \mathrm{mmol})$ at $0{ }^{\circ} \mathrm{C}$. The reaction mixture was allowed to warm to room temperature and stirred overnight. Then, the mixture was quenched with saturated $\mathrm{Na}_{2} \mathrm{~S}_{2} \mathrm{O}_{3}$ solution and partitioned between DCM $(100 \mathrm{~mL})$ and saturated $\mathrm{NaHCO}_{3}(50 \mathrm{~mL})$. The organic layer was washed with saturated brine $(50 \mathrm{~mL})$, dried over sodium sulfate, and concentrated in vacuo. The resulting residue purified by silica gel column chromatography eluting with $10-30 \%$ ethyl acetate in petroleum ether to afford tert-butyl

6-((2-(tert-butyl)-6-chlorobenzo[d]oxazol-7-yl)sulfonyl)-2-azaspiro[3.3]heptane-2-carboxylate (1.6 g, $3.41 \mathrm{mmol}, 67.8 \%$ yield) as a white solid. MS-ESI (m/z): [MH-56 $]^{+} 412.9$.

\section{Step 4: 7-(2-azaspiro[3.3]heptan-6-ylsulfonyl)-2-(tert-butyl)-6-chlorobenzo[d]oxazole}

To a solution of tert-butyl 6-((2-(tert-butyl)-6-chlorobenzo[d]oxazol-7-yl)sulfonyl)-2-azaspiro[3.3]heptane-2-carboxylate $(500 \mathrm{mg}, 1.066 \mathrm{mmol})$ in DCM $(30 \mathrm{~mL})$ was added TFA $(0.082 \mathrm{~mL}, 1.066 \mathrm{mmol})$. The resulting mixture was stirred at room temperature overnight. Then the mixture was concentrated to afford

7-(2-azaspiro[3.3]heptan-6-ylsulfonyl)-2-(tert-butyl)-6-chlorobenzo[d]oxazole, trifluoroacetic acid salt (500 mg, $1.04 \mathrm{mmol}$, $97 \%$ yield). MS-ESI (m/z): $\mathrm{MH}^{+} 369.0$

\section{Step 5: 2-(tert-butyl)-6-chloro-7-((2-methyl-2-azaspiro[3.3]heptan-6-yl)sulfonyl)benzo[d]oxazole}

To a solution of 7-(2-azaspiro[3.3]heptan-6-ylsulfonyl)-2-(tert-butyl)-6-chlorobenzo[d]oxazole, trifluoroacetic acid salt (500 mg, $1.035 \mathrm{mmol})$ and formaldehyde $(0.771 \mathrm{~mL}, 10.35 \mathrm{mmol})$ in DMF $(10 \mathrm{~mL})$ was added AcOH $(0.059 \mathrm{~mL}, 1.035 \mathrm{mmol})$ and sodium triacetoxyborohydride $(219 \mathrm{mg}, 1.035 \mathrm{mmol})$. The resulting mixture was stirred at $0{ }^{\circ} \mathrm{C}$ for $1 \mathrm{~h}$. Then, the mixture was patitioned between ethyl acetate $(50 \mathrm{~mL})$ and saturated $\mathrm{NaHCO}_{3}(50 \mathrm{~mL})$. The organic layer was washed with saturated brine $(50 \mathrm{~mL})$, dried over sodium sulfate, and concentrated in vacuo to afford 2-(tert-butyl)-6-chloro-7-((2-methyl-2-azaspiro[3.3]heptan-6-yl)sulfonyl)benzo[d]oxazole (350 mg, $0.91 \mathrm{mmol}, 88 \%$ yield) as a white solid. MS-ESI (m/z): MH+ 383.0

\section{Step 6: 6-amino-3-chloro-2-((2-methyl-2-azaspiro[3.3]heptan-6-yl)sulfonyl)phenol}

A mixture of 2-(tert-butyl)-6-chloro-7-((2-methyl-2-azaspiro[3.3]heptan-6-yl)sulfonyl)benzo[d]oxazole (500 mg, 1.31 $\mathrm{mmol})$ and $\mathrm{HCl}(0.040 \mathrm{~mL}, 1.31 \mathrm{mmol})$ in 1,4 -Dioxane $(10 \mathrm{~mL})$ and water $(10.00 \mathrm{~mL})$ was stirred at $100{ }^{\circ} \mathrm{C}$ overnight. The reaction mixture was concentrated to afford 6-amino-3-chloro-2-((2-methyl-2-azaspiro[3.3]heptan-6-yl)sulfonyl)phenol, hydrochloride (200 mg, $0.57 \mathrm{mmol}, 43.4 \%$ yield). MS-ESI (m/z): $\mathrm{MH}^{+} 317.0$.

\section{Step 7: 1-(4-chloro-2-hydroxy-3-((2-methyl-2-azaspiro[3.3]heptan-6-yl)sulfonyl)phenyl)-3-(2-chloro-3-fluorophenyl)urea}

To a solution of 6-amino-3-chloro-2-((2-methyl-2-azaspiro[3.3]heptan-6-yl)sulfonyl)phenol (500 mg, $1.578 \mathrm{mmol})$ and triethylamine $(160 \mathrm{mg}, 1.578 \mathrm{mmol})$ in DMF $(10 \mathrm{~mL})$ was added 2-chloro-1-fluoro-3-isocyanatobenzene $(271 \mathrm{mg}, 1.578 \mathrm{mmol})$. The reaction mixture was stirred at room temperature for $1 \mathrm{~h}$. The reaction mixture was directly purified by MDAP to afford 1-(4-chloro-2-hydroxy-3-((2-methyl-2-azaspiro[3.3]heptan-6-yl)sulfonyl)phenyl)-3-(2-chloro-3-fluorophenyl)urea, Trifluoroacetic acid salt (20 mg, $0.033 \mathrm{mmol}, 2.1 \%$ yield) as a white solid. $\left.\delta \mathrm{H} \mathrm{NMR} \mathrm{(400} \mathrm{MHz,} \mathrm{DMSO-} d_{6}\right) 2.63$ (4 H, br. s.), 2.76 (3 H, s), 4.00 (2 H, d, J=11.5 Hz), 4.22 (2 H, br. s.), 4.40 - 4.53 (1 H, m), 7.02 - 7.13 (1 H, m), 7.13 - 7.25 (1 H, m), 7.34 (1 
1-(4-chloro-2-hydroxy-3-((7-methyl-7-azaspiro[3.5]nonan-2-yl)sulfonyl)phenyl)-3-(2-chloro-3-fluorophenyl)urea (28)

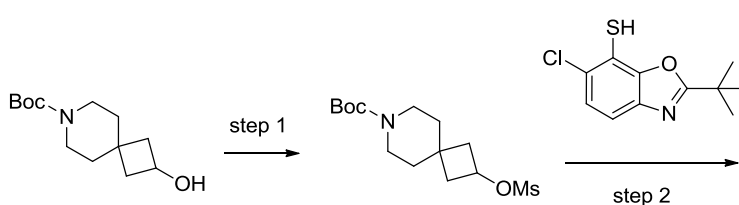

step 2
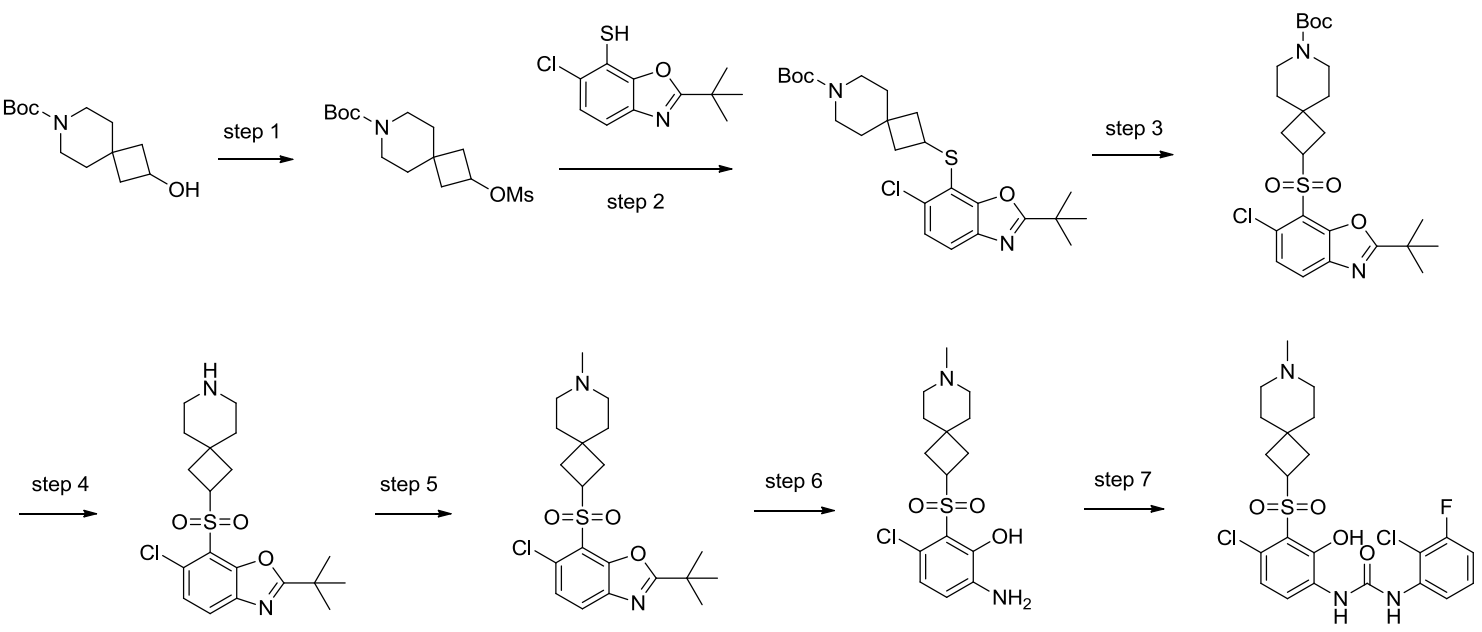

28

\section{Step 1: tert-butyl 2-((methylsulfonyl)oxy)-7-azaspiro[3.5]nonane-7-carboxylate}

To a solution of tert-butyl 2-hydroxy-7-azaspiro[3.5]nonane-7-carboxylate (1.0 g, $4.14 \mathrm{mmol})$ in DCM (50 mL) was added triethylaime $(1.16 \mathrm{~mL}, 8.29 \mathrm{mmol})$ and $\mathrm{MsCl}(0.48 \mathrm{~mL}, 6.22 \mathrm{mmol})$ at $0{ }^{\circ} \mathrm{C}$. The reaction mixture was stirred at this temperature for $30 \mathrm{~min}$. Then, the reaction mixture was quenched with saturated $\mathrm{NaHCO}_{3}$ and patirioned between $\mathrm{DCM}(50 \mathrm{~mL})$ and saturated brine $(50 \mathrm{~mL})$. The organic layer was dried over sodium sulfate, filtered, and concentrated in vacuo to afford tert-butyl 2-((methylsulfonyl)oxy)-7-azaspiro[3.5]nonane-7-carboxylate (1.2 g, $3.76 \mathrm{mmol}, 91 \%$ yield) as a white solid. MS-ESI (m/z): $[\mathrm{M}+\mathrm{Na}]^{+} 342.0$.

\section{Step 2: tert-butyl 2-((2-(tert-butyl)-6-chlorobenzo[d]oxazol-7-yl)thio)-7-azaspiro[3.5]nonane-7-carboxylate}

To a solution of tert-butyl 2-((methylsulfonyl)oxy)-7-azaspiro[3.5]nonane-7-carboxylate (1.2 g, $3.76 \mathrm{mmol})$ and 2-(tert-butyl)-6-chlorobenzo[d]oxazole-7-thiol (1.09 g, $4.51 \mathrm{mmol})$ in DMF (50 mL) was added $\mathrm{K}_{2} \mathrm{CO}_{3}(1.04 \mathrm{~g}, 7.51 \mathrm{mmol}$ ). The reaction mixture was stirred at $120^{\circ} \mathrm{C}$ overnight. The reaction mixture was patitioned betweenethyl acetate ethyl acetate $(200 \mathrm{~mL})$ and water $(100 \mathrm{~mL})$. The organic layer was washed with saturated brine $(100 \mathrm{~mL})$, dried over sodium sulfate and concentrated in vacuo. The resulting residue was purified by silcia gel column chromatography eluting 10-30\% ethyl acetate in petroleum ether to afford tert-butyl 2-((2-(tert-butyl)-6-chlorobenzo[d]oxazol-7-yl)thio)-7-azaspiro[3.5]nonane-7-carboxylate $\left(1.5 \mathrm{~g}, 3.23 \mathrm{mmol}, 86 \%\right.$ yield) as a white solid. MS-ESI (m/z): [M+Na] ${ }^{+} 487.2$.

\section{Step 3: tert-butyl 2-((2-(tert-butyl)-6-chlorobenzo[d]oxazol-7-yl)sulfonyl)-7-azaspiro[3.5]nonane-7-carboxylate}

To a solution of tert-butyl 2-((2-(tert-butyl)-6-chlorobenzo[d]oxazol-7-yl)thio)-7-azaspiro[3.5]nonane-7-carboxylate (1.5 g, $3.23 \mathrm{mmol})$ in DCM $(50 \mathrm{~mL})$ was added mCPBA $(1.45 \mathrm{~g}, 6.45 \mathrm{mmol})$. The reaction mixture was stirred at room temperature overnight. Then, the reaction mixture was quenched with saturated $\mathrm{Na}_{2} \mathrm{~S}_{2} \mathrm{O}_{3}$ solution $(20 \mathrm{~mL})$ and patitioned between DCM (50 $\mathrm{mL})$ and saturated $\mathrm{NaHCO}_{3}$ solution $(50 \mathrm{~mL})$. The organic layer was washed with saturated brine $(50 \mathrm{~mL})$, dried over anhydrous sodium sulfate, and concentrated in vacuo. The resulting residue was purified by silica gel column chromatography eluting with 10-30\% ethyl acetate inpetroleum ether to afford tert-butyl 2-((2-(tert-butyl)-6-chlorobenzo[d]oxazol-7-yl)sulfonyl)-7-azaspiro[3.5]nonane-7-carboxylate (1.0 g, $2.01 \mathrm{mmol}, 62.4 \%$ yield) as a white solid. MS-ESI (m/z): $[\mathrm{M}+\mathrm{Na}]^{+} 519.0$.

\section{Step 4: 7-(7-azaspiro[3.5]nonan-2-ylsulfonyl)-2-(tert-butyl)-6-chlorobenzo[d]oxazole}

To a solution of tert-butyl 2-((2-(tert-butyl)-6-chlorobenzo[d]oxazol-7-yl)sulfonyl)-7-azaspiro[3.5]nonane-7-carboxylate $(0.4 \mathrm{~g}, 0.81 \mathrm{mmol})$ in DCM $(10 \mathrm{~mL})$ was added TFA $(0.62 \mathrm{~mL}, 8.05 \mathrm{mmol})$. The reaction mixture was stirred at room 
temperature overnight. Then, the mixture was concentrated to afford

7-(7-azaspiro[3.5]nonan-2-ylsulfonyl)-2-(tert-butyl)-6-chlorobenzo[d]oxazole, trifluoroacetic acid salt (0.4 g, $0.78 \mathrm{mmol}, 97 \%$ yield) as a white solid. MS-ESI (m/z): $\mathrm{MH}^{+} 397.1$.

\section{Step 5: 2-(tert-butyl)-6-chloro-7-((7-methyl-7-azaspiro[3.5]nonan-2-yl)sulfonyl)benzo[d]oxazole}

To a solution of 7-(7-azaspiro[3.5]nonan-2-ylsulfonyl)-2-(tert-butyl)-6-chlorobenzo[d]oxazole, trifluoroacetic acid salt (0.4 $\mathrm{g}, 0.78 \mathrm{mmol})$, formaldehyde $(0.583 \mathrm{~mL}, 7.83 \mathrm{mmol})$ and acetic acid $(0.045 \mathrm{~mL}, 0.783 \mathrm{mmol})$ in $\mathrm{DMF}(10 \mathrm{~mL})$ at $0{ }^{\circ} \mathrm{C}$ was added sodium triacetoxyborohydride $(0.498 \mathrm{~g}, 2.349 \mathrm{mmol})$. The reaction mixture was stirred at $0{ }^{\circ} \mathrm{C}$ for $10 \mathrm{~min}$. Then, the reaction mixture was quenched with saturated $\mathrm{NaHCO}_{3}$ solution, patitioned between ethyl acetate $(60 \mathrm{~mL})$ and saturated brine $(60 \mathrm{~mL})$. The organic layer was dried over sodium sulfate, filtered, and concentrated in vacuo to afford 2-(tert-butyl)-6-chloro-7-((7-methyl-7-azaspiro[3.5]nonan-2-yl)sulfonyl)benzo[d]oxazole (0.3 g, $0.730 \mathrm{mmol}, 93 \%$ yield) as a white solid. MS-ESI (m/z): $\mathrm{MH}^{+} 411.0$.

\section{Step 6: 6-amino-3-chloro-2-((7-methyl-7-azaspiro[3.5]nonan-2-yl)sulfonyl)phenol}

To a solution of 2-(tert-butyl)-6-chloro-7-((7-methyl-7-azaspiro[3.5]nonan-2-yl)sulfonyl)benzo[d]oxazole (0.4 g, 0.97 $\mathrm{mmol})$ in 1,4-Dioxane $(10 \mathrm{~mL})$ and water $(10 \mathrm{~mL})$ was added $\mathrm{HCl}(1.97 \mathrm{~mL}, 19.47 \mathrm{mmol})$. The reaction mixture was refluxed for $4 \mathrm{~h}$. The reaction mixture was concentrated in vacuo to afford 6-amino-3-chloro-2-((7-methyl-7-azaspiro[3.5]nonan-2-yl)sulfonyl)phenol, 2 Hydrochloride (0.35 g, $0.838 \mathrm{mmol}, 86 \%$ yield) as brown oil. MS-ESI (m/z): $\mathrm{MH}^{+} 345.0$.

\section{Step 7: 1-(4-chloro-2-hydroxy-3-((7-methyl-7-azaspiro[3.5]nonan-2-yl)sulfonyl)phenyl)-3-(2-chloro-3-fluorophenyl)urea}

To a solution of 6-amino-3-chloro-2-((7-methyl-7-azaspiro[3.5]nonan-2-yl)sulfonyl)phenol, hydrochloride (0.4 g, 1.05 $\mathrm{mmol})$ in 1,4-Dioxane $(10 \mathrm{~mL})$ and water $(1.0 \mathrm{~mL})$ was added sodium bicarbonate $(0.176 \mathrm{~g}, 2.1 \mathrm{mmol})$. After stirring at room temperature for $30 \mathrm{~min}, 2$-chloro-1-fluoro-3-isocyanatobenzene $(0.180 \mathrm{~g}, 1.05 \mathrm{mmol})$ was added to the above solution. The reaction mixture was stirred at room temperature for additional $30 \mathrm{~min}$. Then, the solution was diluted with water $(20 \mathrm{~mL})$, extracted with ethyl acetate $(50 \mathrm{~mL}$, twice). The combined organic layers were dried over sodium sulfate, filtered, and concentrated in vacuo. The resulting residue was purified by Mass Directed Autopreparation to afford 1-(4-chloro-2-hydroxy-3-((7-methyl-7-azaspiro[3.5]nonan-2-yl)sulfonyl)phenyl)-3-(2-chloro-3-fluorophenyl)urea, Trifluoroacetic acid salt (106 mg, $0.168 \mathrm{mmol}, 16.0 \%$ yield) as a white solid. ${ }^{1} \mathrm{H}$ NMR (400 MHz, DMSO- $\left.d_{6}\right) \mathrm{d}$ ppm 1.58 $1.78(2 \mathrm{H}, \mathrm{m}), 1.80$ - $2.08(2 \mathrm{H}, \mathrm{m}), 2.09$ - $2.21(2 \mathrm{H}, \mathrm{m}), 2.28(2 \mathrm{H}, \mathrm{m}), 2.71(3 \mathrm{H}, \mathrm{s}), 2.90(2 \mathrm{H}, \mathrm{m}), 3.29(2 \mathrm{H}, \mathrm{m}), 4.62(1 \mathrm{H}$, m), 7.04 - $7.15(1 \mathrm{H}, \mathrm{m}), 7.21(1 \mathrm{H}, \mathrm{d}, J=8.8 \mathrm{~Hz}), 7.35(1 \mathrm{H}, \mathrm{td}, J=8.3,6.5 \mathrm{~Hz}), 7.96(1 \mathrm{H}, \mathrm{d}, J=8.5 \mathrm{~Hz}), 8.33(1 \mathrm{H}, \mathrm{d}, J=8.8 \mathrm{~Hz})$, $9.28(1 \mathrm{H}, \mathrm{s}), 9.37(1 \mathrm{H}, \mathrm{s}), 10.78$ (1 H, br s). $\delta \mathrm{F}$ (DMSO-d, $376 \mathrm{MHz}):-73.7,-113.9$. MS-ESI (m/z): $\mathrm{MH}^{+} 516.1$.

1-(4-chloro-2-hydroxy-3-((3-methyl-3-azaspiro[5.5]undecan-9-yl)sulfonyl)phenyl)-3-(2-chloro-3-fluorophenyl)urea
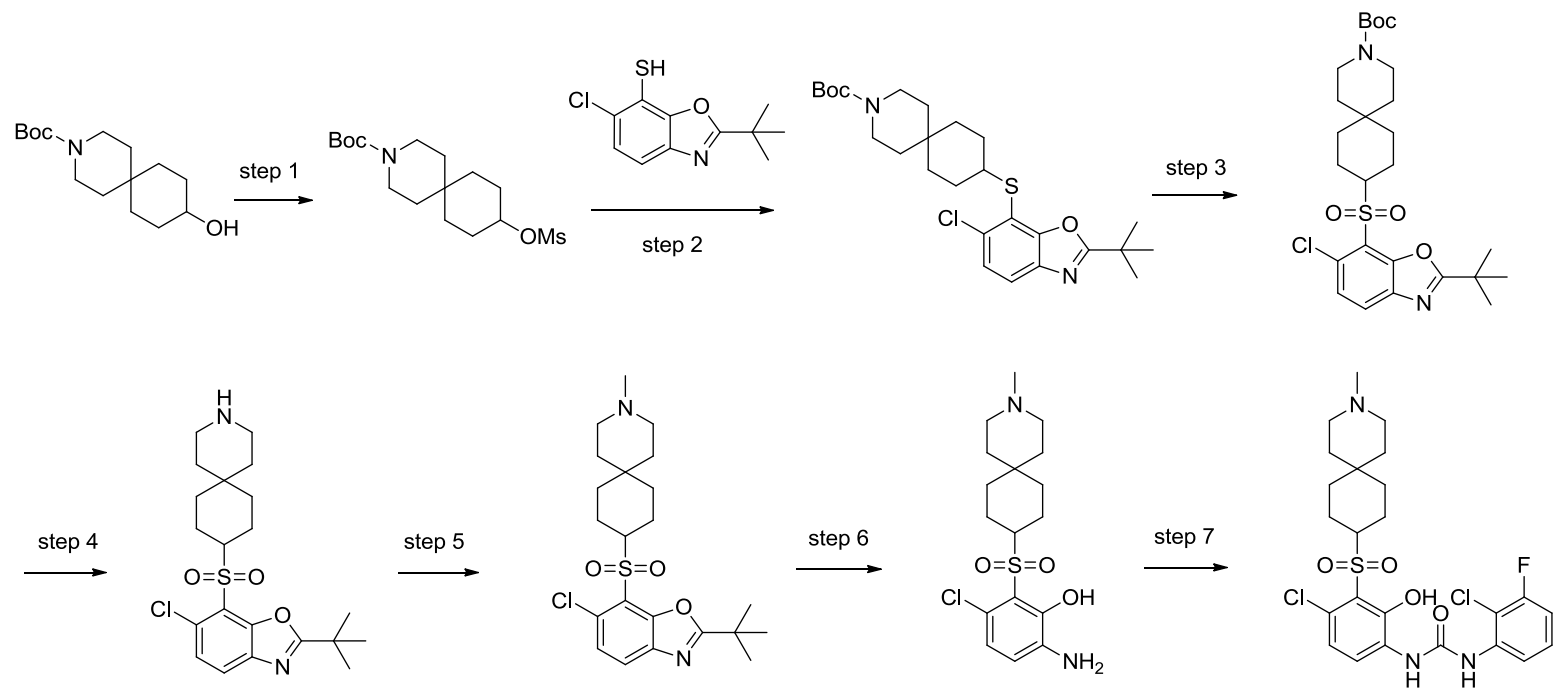


\section{Step 1: tert-butyl 9-((methylsulfonyl)oxy)-3-azaspiro[5.5] undecane-3-carboxylate}

To a solution of tert-butyl 9-hydroxy-3-azaspiro[5.5] undecane-3-carboxylate (1.0 g, $3.71 \mathrm{mmol})$ in DCM (50 mL) was added triethylamine $(1.04 \mathrm{~mL}, 7.42 \mathrm{mmol})$ and $\mathrm{MsCl}(0.43 \mathrm{~mL}, 5.57 \mathrm{mmol})$ at $0{ }^{\circ} \mathrm{C}$. After stirring at $0{ }^{\circ} \mathrm{C}$ for $1 \mathrm{~h}$, the mixture was partitioned between DCM $(50 \mathrm{~mL})$ and saturated $\mathrm{NaHCO}_{3}$ solution $(25 \mathrm{~mL})$. The organic layer was washed with saturated brine $(25 \mathrm{~mL})$, dried over sodium sulfate, and concentrated in vacuo to afford tert-butyl 9-((methylsulfonyl)oxy)-3-azaspiro[5.5]undecane-3-carboxylate (1.40 g, $3.63 \mathrm{mmol}, 98 \%$ yield) as a white solid. MS-ESI $(\mathrm{m} / \mathrm{z}):[\mathrm{MH}-56]^{+} 292.1$.

\section{Step 2: tert-butyl 9-((2-(tert-butyl)-6-chlorobenzo[d]oxazol-7-yl)thio)-3-azaspiro[5.5]undecane-3-carboxylate}

To a solution of tert-butyl 9-((methylsulfonyl)oxy)-3-azaspiro[5.5]undecane-3-carboxylate (1.40 g, $4.03 \mathrm{mmol})$ and 2-(tert-butyl)-6-chlorobenzo[d]oxazole-7-thiol (1461 mg, $6.04 \mathrm{mmol})$ in DMF (100 mL) was added potassium carbonate (1.67 $\mathrm{g}, 12.09 \mathrm{mmol})$. The reaction mixture was heated at $120^{\circ} \mathrm{C}$ overnight. After cooling to room temperature, the mixture was partitioned between ethyl acetate $(200 \mathrm{~mL})$ and water $(200 \mathrm{~mL})$. The organic layer was washed with saturated brine, dried over sodium sulfate, concentrated in vacuo to afford tert-butyl

9-((2-(tert-butyl)-6-chlorobenzo[d]oxazol-7-yl)thio)-3-azaspiro[5.5]undecane-3-carboxylate (3.2 g, $3.89 \mathrm{mmol}, 97 \%$ yield) as a white solid without purification. MS-ESI (m/z): $[\mathrm{M}+\mathrm{Na}]^{+} 515.2$.

\section{Step 3: tert-butyl 9-((2-(tert-butyl)-6-chlorobenzo[d]oxazol-7-yl)sulfonyl)-3-azaspiro[5.5]undecane-3-carboxylate}

To a solution of tert-butyl 9-((2-(tert-butyl)-6-chlorobenzo[d]oxazol-7-yl)thio)-3-azaspiro[5.5]undecane-3-carboxylate (3.2 $\mathrm{g}, 3.89 \mathrm{mmol})$ in DCM $(100 \mathrm{~mL})$ was added mCPBA $(1.92 \mathrm{~g}, 7.79 \mathrm{mmol})$ at $0{ }^{\circ} \mathrm{C}$. The reaction mixture was stirred at room temperature for $3 \mathrm{~h}$. Then, the mixture was quenched with saturated $\mathrm{Na}_{2} \mathrm{~S}_{2} \mathrm{O}_{3}$ solution and partitioned between DCM (150 m) and saturated $\mathrm{NaHCO}_{3}$ solution $(100 \mathrm{~mL})$. The organic layer was washed with saturated brine $(100 \mathrm{~mL})$, dried over sodium sulfate and concentrated in vacuo. The resulting residue was purified by silica gel column chromatography eluting with $10-30 \%$ ethyl acetate in petroleum ether to afford tert-butyl

9-((2-(tert-butyl)-6-chlorobenzo[d]oxazol-7-yl)sulfonyl)-3-azaspiro[5.5]undecane-3-carboxylate (1.3 g, $2.48 \mathrm{mmol}, 63.6 \%$ yield). MS-ESI (m/z): $\mathrm{MH}^{+} 469.2$.

\section{Step 4: 7-(3-azaspiro[5.5]undecan-9-ylsulfonyl)-2-(tert-butyl)-6-chlorobenzo[d]oxazole}

To a solution of tert-butyl 9-((2-(tert-butyl)-6-chlorobenzo[d]oxazol-7-yl)sulfonyl)-3-azaspiro[5.5]undecane-3-carboxylate $(0.5 \mathrm{~g}, 0.95 \mathrm{mmol})$ in DCM $(20 \mathrm{~mL})$ was added TFA $(0.73 \mathrm{~mL}, 9.52 \mathrm{mmol})$. The reaction mixture was stirred at room temperature overnight. The reaction mixture was concentrated to afford the product 7-(3-azaspiro[5.5] undecan-9-ylsulfonyl)-2-(tert-butyl)-6-chlorobenzo[d]oxazole, trifluoroacetic acid salt (0.5 g, $0.928 \mathrm{mmol}$, $97 \%$ yield) as a white solid. MS-ESI (m/z): $\mathrm{MH}^{+} 425.2$.

\section{Step 5: 2-(tert-butyl)-6-chloro-7-((3-methyl-3-azaspiro[5.5]undecan-9-yl)sulfonyl)benzo[d]oxazole}

To a solution of 7-(3-azaspiro[5.5]undecan-9-ylsulfonyl)-2-(tert-butyl)-6-chlorobenzo[d]oxazole, trifluoroacetic acid salt $(0.5 \mathrm{~g}, 0.928 \mathrm{mmol})$ in DMF $(10 \mathrm{~mL})$ was added acetic acid $(0.053 \mathrm{~mL}, 0.93 \mathrm{mmol})$ and formaldehyde $(0.77 \mathrm{~mL}, 9.28 \mathrm{mmol})$. Sodium triacetoxyborohydride $(0.590 \mathrm{~g}, 2.78 \mathrm{mmol})$ was added to the above solution at $0{ }^{\circ} \mathrm{C}$. After stirring at $0{ }^{\circ} \mathrm{C}$ for $20 \mathrm{~min}$, the mixture was partitioned between ethyl acetate $(50 \mathrm{~mL})$ and saturated $\mathrm{NaHCO}_{3}$ solution $(50 \mathrm{~mL})$. The organic layer was washed with saturated brine $(50 \mathrm{~mL})$, dried over sodium sulfate and concentrated in vacuo to afford 2-(tert-butyl)-6-chloro-7-((3-methyl-3-azaspiro[5.5]undecan-9-yl)sulfonyl)benzo[d]oxazole (0.35 g, $0.797 \mathrm{mmol}, 86 \%$ yield). MS-ESI (m/z): $\mathrm{MH}^{+} 439.0$.

\section{Step 6: 6-amino-3-chloro-2-((3-methyl-3-azaspiro[5.5]undecan-9-yl)sulfonyl)phenol}

To a solution of 2-(tert-butyl)-6-chloro-7-((3-methyl-3-azaspiro[5.5]undecan-9-yl)sulfonyl)benzo[d]oxazole (0.35 g, 0.797 $\mathrm{mmol})$ in 1,4-Dioxane $(15 \mathrm{~mL})$ and water $(15.00 \mathrm{~mL})$ was added $\mathrm{HCl}(0.484 \mathrm{~mL}, 15.94 \mathrm{mmol})$. The reaction mixture was stirred at $120^{\circ} \mathrm{C}$ overnight. After cooling to room temperature, the mixture was concentrated under reduced pressure to afford 6-amino-3-chloro-2-((3-methyl-3-azaspiro[5.5]undecan-9-yl)sulfonyl)phenol, hydrochloride (0.3 g, $0.73 \mathrm{mmol}, 92 \%$ yield) as brown oil. MS-ESI (m/z): $\mathrm{MH}^{+} 373.1$. 
Step 7:

1-(4-chloro-2-hydroxy-3-((3-methyl-3-azaspiro[5.5] undecan-9-yl)sulfonyl)phenyl)-3-(2-chloro-3-fluorophenyl)urea

To a solution of 6-amino-3-chloro-2-((3-methyl-3-azaspiro[5.5]undecan-9-yl)sulfonyl)phenol, 2 hydrochloride (0.5 g, $1.121 \mathrm{mmol})$ in 1,4-Dioxane $(10 \mathrm{~mL})$ and water $(1.0 \mathrm{~mL})$ was added sodium bicarbonate $(0.283 \mathrm{~g}, 3.36 \mathrm{mmol})$. After stirring at room temperature for $30 \mathrm{~min}$, 2-chloro-1-fluoro-3-isocyanatobenzene $(0.192 \mathrm{~g}, 1.121 \mathrm{mmol})$ was added to the above solution. The resulting mixture was stirred at room temperature for another $30 \mathrm{~min}$. Then, the solution was diluted with water $(20 \mathrm{~mL})$, extracted with ethyl acetate $(50 \mathrm{~mL}$, twice). The combined organic layers were dried over sodium sulfate, filtered, and concentrated in vacuo. The resulting residue was purified by Mass Directed Autopreparation to afford 1-(4-chloro-2-hydroxy-3-((3-methyl-3-azaspiro[5.5]undecan-9-yl)sulfonyl)phenyl)-3-(2-chloro-3-fluorophenyl)urea, Trifluoroacetic acid salt (70 mg, $0.106 \mathrm{mmol}, 9.48 \%$ yield) as a white solid. $\delta \mathrm{F}$ (DMSO- $\left.d_{6}, 376 \mathrm{MHz}\right):-73.7,-113.9$. MS-ESI $(\mathrm{m} / \mathrm{z}): \mathrm{MH}+544.0 .{ }^{1} \mathrm{H}$ NMR $\left(400 \mathrm{MHz}, \mathrm{DMSO}-d_{6}\right) 1.05$ - $1.60(6 \mathrm{H}, \mathrm{m}), 1.60-1.85(4 \mathrm{H}, \mathrm{m}), 2.03(1 \mathrm{H}, \mathrm{m}), 2.22(1 \mathrm{H}, \mathrm{m})$, $2.78(3 \mathrm{H}, \mathrm{s}), 3.02(2 \mathrm{H}, \mathrm{m}), 3.22(2 \mathrm{H}, \mathrm{m}), 3.68(1 \mathrm{H}, \mathrm{m}), 7.05-7.14(1 \mathrm{H}, \mathrm{m}), 7.22(1 \mathrm{H}, \mathrm{d}, \mathrm{J}=8.8 \mathrm{~Hz}), 7.34(1 \mathrm{H}, \mathrm{td}, J=8.3,6.5$ Hz), 7.95 (1 H, d, J=8.5 Hz), 8.37 (1 H, d, $J=8.8 \mathrm{~Hz}), 9.28$ (1 H, s), 9.35 (1 H, s), 10.78 (1 H, br s). $\delta \mathrm{F}$ (DMSO- $\left.d_{6}, 376 \mathrm{MHz}\right)$ : -113.9. MS-ESI (m/z): $\mathrm{MH}^{+}$544.0.

\section{N-(2-chloro-3-fluorophenyl)-N'-[4-chloro-2-hydroxy-3-(1-pyrrolidinylcarbonyl)phenyl]urea (30)}<smiles>N#Cc1c(F)cccc1Cl</smiles>

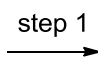<smiles>N#Cc1c(O)cccc1Cl</smiles><smiles>N#Cc1c(Cl)ccc([N+](=O)[O-])c1O</smiles>

step 3

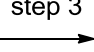<smiles>NC(=O)c1c(Cl)ccc([N+](=O)[O-])c1O</smiles><smiles>Nc1ccc(Cl)c(C(=O)N2CCCC2)c1O</smiles>

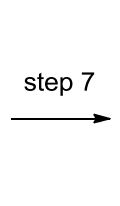

Step 1: 2-chloro-6-hydroxybenzonitrile

To a solution of 2-chloro-6-fluorobenzonitrile (12 g, $77 \mathrm{mmol})$ and sodium hydride $(8.54 \mathrm{~g}, 231 \mathrm{mmol})$ in THF (150 mL) was added a solution of 2-(methylsulfonyl)ethanol $(12.45 \mathrm{~g}, 100 \mathrm{mmol})$ in THF $(150 \mathrm{~mL})$. The reaction mixture was stirred at room temperature for $30 \mathrm{~min}$. The reaction mixture was quenched with $2 \mathrm{M} \mathrm{HCl}(50 \mathrm{~mL})$ at $0{ }^{\circ} \mathrm{C}$ and partitioned between ethyl acetate $(100 \mathrm{~mL})$ and water $(100 \mathrm{~mL})$. The organic layer was washed with saturated brine, dried over sodium sulfate, and concentrated to give 2-chloro-6-hydroxybenzonitrile (11.8 g, $77 \mathrm{mmol}, 100 \%$ yield) as a gray solid. MS-ESI (m/z): $\mathrm{MH}^{+} 154.0$.

\section{Step 2: 6-chloro-2-hydroxy-3-nitrobenzonitrile}

2-chloro-6-hydroxybenzonitrile ( $5 \mathrm{~g}, 32.6 \mathrm{mmol})$ was dissolved in nitric acid $(40 \mathrm{ml}, 895 \mathrm{mmol})$ at room temperature. The suspension mixture was allowed to warm to $30^{\circ} \mathrm{C}$ and stirred until the solution turned clear. After cooling to room temperature, the mixture was poured into ice, partitioned between ethyl acetate $(100 \mathrm{~mL})$ and saturated brine $(100 \mathrm{~mL})$. The organic layer was dried over sodium sulfate, filtered and concentrated in vacuo. The resulting residue was purified by silica gel column chromatography eluting with $0-100 \%$ ethyl acetate in petroleum ether to give 6-chloro-2-hydroxy-3-nitrobenzonitrile (6.0 g, $30.2 \mathrm{mmol}, 30.9 \%$ yield) as a white solid.

\section{Step 3: 6-chloro-2-hydroxy-3-nitrobenzamide}

6-chloro-2-hydroxy-3-nitrobenzonitrile (5g, $25.2 \mathrm{mmol})$ was dissolved in $\mathrm{H}_{2} \mathrm{SO}_{4}(10 \mathrm{~mL}, 188 \mathrm{mmol})$ at room temperature. The mixture was heated to $70{ }^{\circ} \mathrm{C}$ and stirred for $6 \mathrm{~h}$. The reaction mixture was poured into ice and partitioned between ethyl acetate $(200 \mathrm{~mL})$ and water $(100 \mathrm{~mL})$. The organic layer was washed with saturated brine $(100 \mathrm{~mL})$, dried over sodium sulfate, 
and concentrated to give 6-chloro-2-hydroxy-3-nitrobenzamide (4.36 g, $20.14 \mathrm{mmol}, 80 \%$ yield) as brown solid. MS-ESI (m/z): $\mathrm{MH}^{+}$217.0.

\section{Step 4: 6-chloro-2-hydroxy-3-nitrobenzoic acid}

To a solution of 6-chloro-2-hydroxy-3-nitrobenzamide (1g, $4.62 \mathrm{mmol})$ in $80 \%$ of $\mathrm{H}_{2} \mathrm{SO}_{4}(8 \mathrm{~mL}, 120 \mathrm{mmol})$ at $10 \sim 15{ }^{\circ} \mathrm{C}$ was added slowly beneath the surface of the liquid a solution of sodium nitrite $(1.3 \mathrm{~mL}, 13.00 \mathrm{mmol})$. The reaction was heated to $100{ }^{\circ} \mathrm{C}$ and stirred for $50 \mathrm{~min}$. After cooling to room temperature, the mixture was partitioned between ethyl acetate (50 $\left.\mathrm{mL}\right)$ and saturated brine $(50 \mathrm{~mL})$. The organic layer was dried over sodium sulfate, concentrated in vacuo to give 6-chloro-2-hydroxy-3-nitrobenzoic acid (942 mg, $3.90 \mathrm{mmol}, 84 \%$ yield) as a brown solid, which was directly used for next step without further purification.

\section{Step 5: 3-chloro-6-nitro-2-(1-pyrrolidinylcarbonyl)phenol}

To a solution of 6-chloro-2-hydroxy-3-nitrobenzoic acid (900 mg, $4.14 \mathrm{mmol}$ and catalytic DMF (3.20 $\mu \mathrm{L}, 0.041 \mathrm{mmol}) \mathrm{in}$ dry DCM $(20 \mathrm{~mL})$ at $0{ }^{\circ} \mathrm{C}$ was added oxalyl chloride $(0.72 \mathrm{~mL}, 8.27 \mathrm{mmol})$. The mixture was gradually warmed to room temperature and stirred for $3 \mathrm{~h}$. The mixture was concentrated in vacuo and re-dissolved in THF (20 mL). To the above solution was added a solution of pyrrolidine $(412 \mathrm{mg}, 5.79 \mathrm{mmol})$ and triethylamine $(1.15 \mathrm{~mL}, 8.27 \mathrm{mmol})$ in $\mathrm{THF}(20 \mathrm{~mL})$ at $0{ }^{\circ} \mathrm{C}$. After stirring at room temperature overnight, the mixture was quenched with $\mathrm{H}_{2} \mathrm{O}(10 \mathrm{~mL})$, and partitioned between ethyl acetate $(50 \mathrm{~mL})$ and saturated brine $(50 \mathrm{~mL})$. The organic layer was dried over sodium sulfate, concentrated in vacuo. The resulting residue was purified by silica gel column chromatography eluting with 0-100\% ethyl acetate in petroleum ether to afford 3-chloro-6-nitro-2-(1-pyrrolidinylcarbonyl)phenol (900 mg, $3.33 \mathrm{mmol}, 80 \%$ yield) as a brown solid. MS-ESI (m/z): $\mathrm{MH}^{+} 271.1$.

\section{Step 6: 6-amino-3-chloro-2-(1-pyrrolidinylcarbonyl)phenol}

To a solution of 3-chloro-6-nitro-2-(1-pyrrolidinylcarbonyl)phenol (900 mg, $3.33 \mathrm{mmol})$ in Methanol (300 mL) at room temperature was added nickel $(1.951 \mathrm{mg}, 0.033 \mathrm{mmol})$. The reaction mixture was stirred at room temperature under hydrogen overnight. The mixture was filtered and the filtration was concentrated to give 6-amino-3-chloro-2-(1-pyrrolidinylcarbonyl)phenol (600 mg, $1.99 \mathrm{mmol}, 60.0 \%$ yield) as a black solid. MS-ESI (m/z): MH 241.1 .

\section{Step 7: N-(2-chloro-3-fluorophenyl)-N'-[4-chloro-2-hydroxy-3-(1-pyrrolidinylcarbonyl)phenyl]urea}

To a solution of 3-chloro-6-nitro-2-(1-pyrrolidinylcarbonyl)phenol (120 mg, $0.443 \mathrm{mmol})$ in DMF (6 mL) at room temperature was added 2-chloro-1-fluoro-3-isocyanatobenzene $(152 \mathrm{mg}, 0.887 \mathrm{mmol})$. The reaction mixture was stirred at room temperature overnight. The resulting solution was directly purified by Mass Directed Autopreparation to afford N-(2-chloro-3-fluorophenyl)-N'-[4-chloro-2-hydroxy-3-(1-pyrrolidinylcarbonyl)phenyl]urea (51 mg, $0.092 \mathrm{mmol}, 20.8 \%$ yield) as a brown solid. ${ }^{1} \mathrm{H}$ NMR (600 MHz, DMSO-d $\left.d_{6}\right) 1.81$ - 1.88 (4 H, m), 3.05 - $3.14(2 \mathrm{H}, \mathrm{m}), 3.32$ - 3.54 (2 H, m), 6.97 (1 H, d, $J=8.4 \mathrm{~Hz}), 7.07(1 \mathrm{H}, \mathrm{t}, J=8.7 \mathrm{~Hz}), 7.33(1 \mathrm{H}, \mathrm{m}), 7.91(1 \mathrm{H}, \mathrm{d}, J=9.0 \mathrm{~Hz}), 7.97(1 \mathrm{H}, \mathrm{d}, J=7.2 \mathrm{~Hz}), 9.13(1 \mathrm{H}, \mathrm{s}), 9.20$ (1 H, s), $9.91(1 \mathrm{H}, \mathrm{s}) . \delta \mathrm{F}\left(\mathrm{DMSO}-d_{6}, 376 \mathrm{MHz}\right):-114.02 . \mathrm{MS}-\mathrm{ESI}(\mathrm{m} / \mathrm{z}): \mathrm{MH}^{+} 412.0$.

\section{N-(2-chloro-3-fluorophenyl)-N'-[4-chloro-2-hydroxy-3-(1-piperidinylcarbonyl)phenyl]urea (31)}
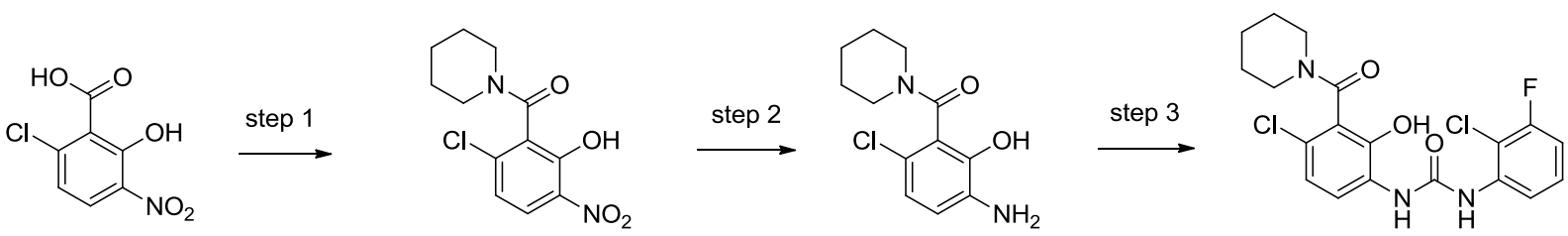

31

\section{Step 1: 3-chloro-6-nitro-2-(1-pyrrolidinylcarbonyl)phenol}

To a solution of 6-chloro-2-hydroxy-3-nitrobenzoic acid (900 mg, $4.14 \mathrm{mmol}$ ) and catalytic DMF (3.20 $\mu \mathrm{L}, 0.041 \mathrm{mmol})$ in dry DCM $(20 \mathrm{~mL})$ at $0{ }^{\circ} \mathrm{C}$ was added oxalyl chloride $(0.72 \mathrm{~mL}, 8.27 \mathrm{mmol})$. The mixture was gradually warmed to room 
temperature and stirred for $3 \mathrm{~h}$. Then, the mixture was concentrated in vacuo and re-dissolved in THF (20 mL). To the above solution was dropwise added a solution of pyrrolidine $(412 \mathrm{mg}, 5.79 \mathrm{mmol})$ and triethylamine $(1.15 \mathrm{~mL}, 8.27 \mathrm{mmol})$ in THF $(20 \mathrm{~mL})$ at $0{ }^{\circ} \mathrm{C}$. The reaction mixture was warmed to room temperature and stirred overnight. The reaction mixture was quenched with $\mathrm{H}_{2} \mathrm{O}(10 \mathrm{~mL})$, and partitioned between DCM $(50 \mathrm{~mL})$ and saturated brine $(25 \mathrm{~mL})$. The organic layer was dried over sodium sulfate and concentrated in vacuo. The resulting residue was purified by silica gel column chromatography eluting with 0-100\% ethyl acetate in petroleum ether to give 3-chloro-6-nitro-2-(1-pyrrolidinylcarbonyl)phenol (900 mg, $3.33 \mathrm{mmol}$, $80 \%$ yield) as a brown solid. MS-ESI (m/z): $\mathrm{MH}+271.1$.

\section{Step 2: 6-amino-3-chloro-2-(1-piperidinylcarbonyl)phenol}

To a solution of 3-chloro-6-nitro-2-(1-piperidinylcarbonyl)phenol (830 mg, $2.92 \mathrm{mmol})$ in Methanol (30 mL) was added nickel $(1.71 \mathrm{mg}, 0.029 \mathrm{mmol})$. The reaction mixture was stirred at room temperature under hydrogen overnight. Then, the mixture was filtered through a celite pad and the filtrate was concentrated in vacuo to give 6-amino-3-chloro-2-(1-piperidinylcarbonyl)phenol (660 mg, $2.59 \mathrm{mmol}, 89 \%$ yield) as a black solid. MS-ESI (m/z): MH 255.1.

\section{Step 3: N-(2-chloro-3-fluorophenyl)-N'-[4-chloro-2-hydroxy-3-(1-piperidinylcarbonyl)phenyl]urea}

To a solution of 6-amino-3-chloro-2-(1-piperidinylcarbonyl)phenol (120 mg, $0.471 \mathrm{mmol})$ in DMF (5 mL) was added 2-chloro-1-fluoro-3-isocyanatobenzene (105 $\mathrm{mg}, 0.612 \mathrm{mmol})$. The reaction mixture was stirred at room temperature overnight. The solution was directly purified by Mass Directed Autopreparation to afford N-(2-chloro-3-fluorophenyl)-N'-[4-chloro-2-hydroxy-3-(1-piperidinylcarbonyl)phenyl]urea (55 mg, $0.12 \mathrm{mmol}, 26.0 \%$ yield) as a brown solid. ${ }^{1} \mathrm{H}$ NMR $\left(600 \mathrm{MHz}, \mathrm{DMSO}-d_{6}\right) 1.46-1.63(6 \mathrm{H}, \mathrm{m}), 3.12(2 \mathrm{H}, \mathrm{m}), 3.52(1 \mathrm{H}, \mathrm{m}), 3.73(1 \mathrm{H}, \mathrm{m}), 6.97(1 \mathrm{H}$, d, $J=9.0 \mathrm{~Hz}), 7.07(1 \mathrm{H}, \mathrm{t}, J=8.7 \mathrm{~Hz}), 7.33(1 \mathrm{H}, \mathrm{m}), 7.89(1 \mathrm{H}, \mathrm{d}, J=9.0 \mathrm{~Hz}), 7.98(1 \mathrm{H}, \mathrm{d}, J=8.4 \mathrm{~Hz}), 9.12(1 \mathrm{H}, \mathrm{s}), 9.20(1 \mathrm{H}, \mathrm{s})$, 9.89 (1 H, s). $\delta \mathrm{F}\left(\mathrm{DMSO}-d_{6}, 376 \mathrm{MHz}\right):-114.02$. MS-ESI (m/z): $\mathrm{MH}^{+} 426.1$.

\section{CXCR2 Tango Assay}

The assay measures ligand-induced activation of the receptor CXCR2 in a stable cell line containing the recombinant human CXCR2 linked to a TEV protease site and a Gal4-VP16 transcription factor (Invitrogen). Ligand binding to the receptor results in the recruitment of arrestin proteins (tagged with protease) to the receptor and triggers the release of a tethered transcription factor. The transcription factor enters the nucleus and activates the transcription of the reporter gene. The ability of a compound to inhibit CXCR2 activation is indirectly assessed by measuring the reporter gene activity.

Cells were starved for 24 hours at $37^{\circ} \mathrm{C}, 5 \% \mathrm{CO}_{2}$, harvested and resuspended in assay medium at a density 200,000 cells $/ \mathrm{ml}$. All test compounds were dissolved in DMSO at a concentration of $10 \mathrm{mM}$ and were prepared in $100 \%$ DMSO to provide 9 point concentration response curves. The CXCR2 antagonist N-(3-(aminosulfonyl)-4-chloro-2-hydroxyphenyl)-N'-(2,3-dichlorophenyl) urea (Podolin et al. (2002) J. Immunol. 169: 6435-6444) was added to wells in row 2, columns 2-10 as reference compound. Test compounds were added to wells in row 2 , columns 13-21 and rows 3-15, columns 2-10/13-21 (row 1 and 16 were left empty and not used). Compounds in solution were added to the assay plate (Greiner 781090) using an Echo (Labcyte) concentration-response program (50nl/well). The cell-free, un-stimulated and positive control (SB-332235) were loaded with $50 \mathrm{nl} /$ well pure DMSO to ensure that the DMSO concentration was constant across the plate for all assays. 50 $\mu$ l of the cell suspension without hCXCL1 (a CXCR2 ligand) was added to each well in columns 12 and 23 of the plate ( 10,000 cells per well). 50 $\mu$ l of the cell suspension with $80 \mathrm{nM} \mathrm{hCXCL1}$ was added to each well in columns $2-11 / 13-22$ of the plate $(\sim 10,000$ cells per well). $50 \mu 1$ of assay medium was added to each well in the cell-free controls (columns 1 and 24). The cells were incubated overnight at $37^{\circ} \mathrm{C} / 5 \% \mathrm{CO}_{2} .10 \mu 1$ of $6 \times$ substrate mixture (LiveBLAzerTM-FRET B/G substrate (CCF4-AM) Cat \# K1096 from Invitrogen, Inc.) was added to each well using Bravo and the plates incubated at room temperature for $2 \mathrm{~h}$ in the dark. The plate was finally read on EnVision using one excitation channel (409 $\mathrm{nm}$ ) and two emission channels (460 $\mathrm{nm}$ and $530 \mathrm{~nm}$ ). 
The blue/green emission ratio $(460 \mathrm{~nm} / 530 \mathrm{~nm})$ was calculated for each well, by dividing the background-subtracted Blue emission values by the background-subtracted Green emission values. The concentration response curve was based on sigmoidal concentration-response model. All ratio data was normalized based upon the maximum emission ratio of positive control (hCXCL1) and minimum emission ratio of negative control (DMSO) on each plate. The intrinsic activity (IA) of each compound would be the normalized percentage of its maximum response after curve fitting.

\section{Neutrophil Chemotaxis Assay}

The assay measures the ability of a compound to inhibit neutrophil chemotaxis induced by CXCL1 in vitro. All reagents were supplied by Invitrogen unless otherwise stated. The Neutrophils were prepared from the human whole blood. Blood, obtained from GSK Stevenage blood donation unit, was withdrawn by vein puncture from consented healthy donor panel adults and poured into a Sterilin tube containing an anti-coagulant citrate buffer. Hertfordshire Research Ethics Committee ethically approves all procedures: 07/H0311/103. All biological samples used in the study were compliant with GSK Global Policies on Human Biological Tissue (POL-GSKF-410 and SOP-GSKF-410: Management of Human Biological Samples in Research). Human whole blood was treated with 20\% HetaSep solution (StemCell Technologies, France) and incubated for $\sim 45 \mathrm{~min}$ at $37^{\circ} \mathrm{C}, 5 \% \mathrm{CO}_{2}$ to sediment red blood cells. Plasma fraction was subsequently treated with 4 parts Neutrophil medium (PBS without calcium or magnesium, 2\% FBS, 1mM EDTA) to 1 part plasma fraction to pellet cells. Cells were then resuspended in Neutrophil medium to $5 \times 10^{7}$ cells $/ \mathrm{ml}$. Neutrophils were isolated from other cells using an EasySep Human Neutrophil Enrichment Kit (StemCell Technologies, France) and Silver EasySep Magnet (StemCell Technologies, France). Neutrophils were then resuspended to $2 \times 10^{6}$ cells $/ \mathrm{ml}$ in Assay medium (RPMI (phenol red free), 10\% FBS).

Test compounds were used at a top final assay concentration of $33.3 \mu \mathrm{M}$, diluted in assay medium with 1:3 dilutions to produce 10 point concentration responses. Test compounds were incubated with neutrophils for 60 min at $37^{\circ} \mathrm{C}, 5 \% \mathrm{CO}_{2}$ in an assay volume of $60 \mu 1$. After incubation, the chemotaxis reaction was measured using a $5 \mu \mathrm{m}$ NeuroprobeChemoTx plate plus membrane (Receptor Technology RTL (Neuroprobe), USA) using the following protocol: 100nM Recombinant Human CXCL1 (R\&D Systems, USA) in PBS (assay volume 32.5 $\mu$ ) was added to each well of the plate. The membrane was fixed to the plate and cell suspension with compound added on top of membrane in a volume of $50 \mu$ l. Plates were then incubated at $37^{\circ} \mathrm{C}, 5 \%$ $\mathrm{CO}_{2}$ for $45 \mathrm{~min}$. Cell suspension was aspirated from the surface of the membrane and the membrane was separated from the

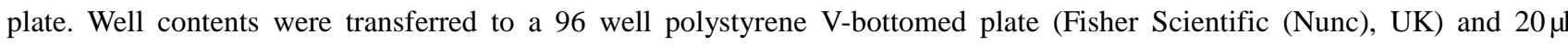
Calcein-AM (final assay concentration $15 \mu \mathrm{g} / \mathrm{ml}$ ) added to each well. Plates were incubated for $30 \min$ at $37^{\circ} \mathrm{C}, 5 \% \mathrm{CO}_{2}$. Neutrophils were then pelleted and resuspended in PBS to wash away Calcein-AM left in the solution before pelleting again and reading on an Envision Plate Reader (Perkin Elmer, USA) at $485 \mathrm{~nm}_{\text {excitation, }} 535 \mathrm{~nm}_{\text {emmission. }}$.IC50 values were determined from compound titration data using Activitybase XE software (IDBS, UK) and applying the four parameter logistic equation (Kuzmicet al. (2000) Anal. Biochem.281: 62-67).

\section{$\underline{\text { CNS Penetration }}$}

The blood brain and blood cerebrospinal fluid barriers separate the brain from the systemic circulation. These barriers have tight junctions and multiple drug transporters that need to be navigated physiochemically to enable CNS exposure of compounds to reach and engage their CNS molecular target. CNS penetration of CXCR2 compounds was evaluated in C57BL/6 mice following an intraperitoneal administration of $2 \mathrm{mg} / \mathrm{kg}$. Test compound was formulated as homogenous suspension in a dosing vehicle containing DMSO:1\% methylcellulose $(\mathrm{w} / \mathrm{v})=1: 99$. At each time point post dose $(1,2 \mathrm{and} 4 \mathrm{hr})$, blood samples were collected from two animals into heparin-coated capillary tubes. Exact 40uL of whole blood was then diluted with 2 folds of deionized water. Immediately after blood collection, animal was scarified and brain tissue was isolated. After rinsing with cold deionized water and removal of surface vasculature, brain tissue was dried, weighed and homogenized 
after addition of 3 folds of phosphate buffered saline.

Two separate calibration curves were prepared in blank blood/water mixture and brain homogenate respectively. Study samples and their corresponding calibration curves were extracted by protein precipitation. Exact 50uL sample was aliquot into a clean extract plate and then $150 \mathrm{uL}$ of acetonitrile containing analytical internal standard was added to each sample. After mixing and centrifugation, approximate $100 \mathrm{uL}$ of supernatant was removed into an injection plate and sample was further diluted with same volume of deionized water. Quantitation of test compound was carried out by UPLC/MS/MS using an optimized methodology.

Systemic and brain exposure were estimated by area under curve (AUC) up to last time point at 4 hr. CNS penetration potential of test compound was evaluated from the ratio of $\mathrm{AUC}_{\text {brain }} / \mathrm{AUC}_{\mathrm{blood}}$.

\section{Cuprizone-induced demyelination model}

6-8 weeks old male C57BL/6 mice were fed with a diet of powdered mouse chow containing $0.2 \%$ (w/w) cuprizone (Biscyclohexane oxaldihydrazone, Sigma-Aldrich, St. Louis, MO) ad libitum for a period of 5 weeks to induce demyelination. Mice were then returned to normal chow for 9 days and treated with $1 \%$ methyl cellulose (vehicle) to assess spontaneous remyelination or CXCR2 antagonist in solution (DMSO/1\% methyl cellulose, 1:99) at $30 \mathrm{mg} / \mathrm{kg}$ or $100 \mathrm{mg} / \mathrm{kg}$ twice daily via oral gauage to assess potential for accelerated remyelination compared to vehicle. At the end of study, mice were perfused with PBS and brains were dissected and post fixed in 4\% paraformaldehyde followed by dehydration in $30 \%$ sucrose. Brain samples were then dissected into forebrain and hindbrain, frozen embedded in OCT separately, and sectioned with cryostat (MICROM HM250) at a thickness of $30 \mu \mathrm{m}$. The coronal sections were stained with $0.3 \%$ Black-Gold II (Millipore) solution in saline. Briefly, sections were washed with MilliQ $\mathrm{H}_{2} \mathrm{O}$ for $2 \mathrm{~min}$, then incubated in $0.3 \%$ Black-Gold solution at $60^{\circ} \mathrm{C}$ for $20 \mathrm{~min}$, rinsed twice with MilliQ $\mathrm{H}_{2} \mathrm{O}$ for 2 min each, and incubated with sodium thiosulfate solution (1\%) for 6 minutes at $60^{\circ} \mathrm{C}$. Sections were then rinsed twice with MilliQ water for 2 minutes each, dehydrated with a series of gradated alcohols and mounted. Digital images of corpus callosum were captured using ImageScope (Aperio, Leica) at the 20x magnification. Image-Pro 6.3 software (Media Cybernetics, Bethesda, MD 20814 USA) was used for subsequent quantitative evaluation. Area and IOD (Integrated Optical Density) were measured and mean density (IOD/area) was calculated. One-way ANOVA analysis with Newman-Keuls multiple comparison test performed by GraphPad5 PRISM software (GraphPad Software, Inco, San Diego, Calif., USA) was used to analyze the difference between groups. P value $<0.05$ was considered statistically significant as shown in Figure 2. 